\title{
Wyndham Lewis's Kulturkampf
}

\author{
by \\ David William Lafferty, B.A. (Hons), M.A.
}

\author{
A thesis submitted to \\ the Faculty of Graduate Studies and Research \\ in partial fulfillment of \\ the requirements for the degree of
}

Doctor of Philosophy

Institute of Comparative Studies in Literature, Art, and Culture:

Cultural Mediations

\author{
Carleton University \\ Ottawa, Canada \\ January, 2009 \\ (C) 2009, David William Lafferty
}


Library and

Archives Canada

Published Heritage

Branch

395 Wellington Street

Ottawa ON K1A 0N4

Canada
Bibliothèque et

Archives Canada

Direction du

Patrimoine de l'édition

395 , rue Wellington

Ottawa ON K1A 0N4

Canada

Your file Votre référence

ISBN: 978-0-494-52094-9

Our file Notre référence

ISBN: 978-0-494-52094-9

NOTICE:

The author has granted a nonexclusive license allowing Library and Archives Canada to reproduce, publish, archive, preserve, conserve, communicate to the public by telecommunication or on the Internet, loan, distribute and sell theses worldwide, for commercial or noncommercial purposes, in microform, paper, electronic and/or any other formats.

The author retains copyright ownership and moral rights in this thesis. Neither the thesis nor substantial extracts from it may be printed or otherwise reproduced without the author's permission.
AVIS:

L'auteur a accordé une licence non exclusive permettant à la Bibliothèque et Archives Canada de reproduire, publier, archiver, sauvegarder, conserver, transmettre au public par télécommunication ou par l'Internet, prêter, distribuer et vendre des thèses partout dans le monde, à des fins commerciales ou autres, sur support microforme, papier, électronique et/ou autres formats.

L'auteur conserve la propriété du droit d'auteur et des droits moraux qui protège cette thèse. $\mathrm{Ni}$ la thèse ni des extraits substantiels de celle-ci ne doivent être imprimés ou autrement reproduits sans son autorisation.
In compliance with the Canadian

Privacy A'ct some supporting forms may have been removed from this thesis.

While these forms may be included in the document page count, their removal does not represent any loss of content from the thesis.
Conformément à la loi canadienne sur la protection de la vie privée, quelques formulaires secondaires ont été enlevés de cette thèse.

Bien que ces formulaires aient inclus dans la pagination, il n'y aura aucun contenu manquant.

\section{Canadä}




\begin{abstract}
The claim of this study is that the "master subject" of Lewis's literary works was a cultural divide that I refer to as the modern kulturkampf or "culture war" (the English translation of kulturkampf, and now common parlance), and that may be most simply described as the sharp, politicized cultural division between the Old and the New in the modern world. Lewis's confrontation with the kulturkampf, the parameters of which he was constantly redefining, guided his rhetorical strategies and the construction of his authorial persona, especially in his employment of reactionary ideas and rhetoric. I examine the development of Lewis's vision of the kulturkampf in his polemical works and in the fiction in which his polemical voice and authorial persona are most apparent, analyzing in loose chronological order the emergence of Lewis's "politics of the intellect" in The Art of Being Ruled (1926) and The Lion and the Fox (1927); his engagement with kulturkampf rhetoric in his critique of T.E. Hulme's vision of the kulturkampf, his public feud with the editors of transition, and his analysis of the age war in The Old Gang and the New Gang (1933); his political polemics of the 1930s, with a focus on his contribution to "revolutionary conservative" ideology in Count Your Dead: They Are Alive! (1937); his post-war return to the British kulturkampf in Rotting Hill (1951); and finally his radical re-evaluation of the dimensions of the kulturkampf in the last two completed books of the unfinished Human Age tetralogy.
\end{abstract}

Throughout, I argue that the purpose of Lewis's engagement with the kulturkampf was threefold. First, it allowed him to refine his politics of the intellect-the practical goal of which was the protection of the intellectual, and the utopian goal of which was to bring 
the kulturkampf into a new "political equilibrium." Second, it allowed him to harness the literary and political violence of others as a means of creating confusion and controversy, thus reinforcing his position as the "Enemy." Third, it functioned as a vehicle for his evangelical impulses, his goal being to expand the political consciousness of the average middle-class Briton. 


\section{Acknowledgments}

Many people deserve thanks for their help in the completion of this project. These include my supervisor, Chris Faulkner, for the invaluable advice and encouragement he offered throughout the writing process; my readers Jodie Medd and Don Childs, for their thoughtful criticism; my external examiner Raphael Foshay; and my internal/external examiner Deborah Gorham. The faculty and staff of the Cultural Mediations department were accommodating throughout, and provided an intellectual environment in which a project such as this could develop.

I would like to offer special thanks to my wife, Tobi, for her love, patience, and truly exceptional editing skills. Others to whom I owe a debt of gratitude include my parents, Bill and Draha, for their love and support from the beginning of my educational journey; my sister, Katie; my extended family, Ed, Iris, and Andrew Kozakewich; Stephen Chesine; and Bijou the cat, who helped keep my notes from flying away. Financial assistance for this project included generous funding from Carleton University and the Cultural Mediations program, the Ontario Graduate Scholarship Program, and the Margaret Wade Labarge Graduate Student Research Fund. My deepest debt, however, is to God, "from Whom all good things come." 


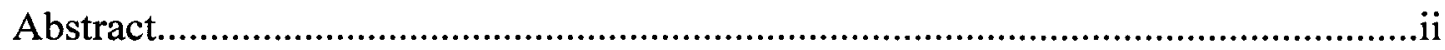

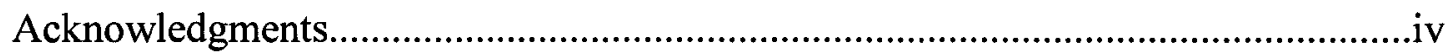

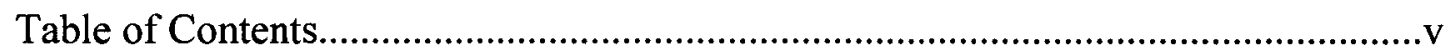

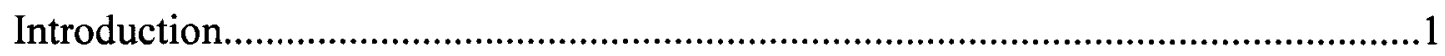

Chapter One

Riddles of the Sphinx: The Diremption of the Kulturkampf in

The Lion and the Fox and The Art of Being Ruled..............................................30

Chapter Two

A White Man in a Dark Shirt: The Enemy and the Kulturkampf...........................63

Chapter Three

Castor Oil for Conservatives?: Wyndham Lewis and Fascism.

Chapter Four

"I Wish to Be an Integral Social Being"": The Post-War Kulturkampf

and the Fate of the Clercs in Rotting Hill....

Chapter Five

Signs of God: The Failure of the "Politics of the Intellect" in

Monstre Gai and Malign Fiesta.

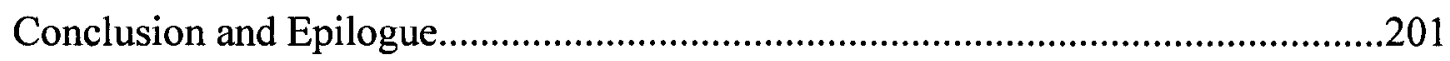

Bibliography of Works Cited and Consulted................................................218 


\section{Introduction}

In The Lion and the Fox, a 1927 study of William Shakespeare's tragedies, Wyndham Lewis describes the cultural divide in the English Renaissance between an old medievalism and an emerging modernism as the "master subject" of Shakespeare's work. ${ }^{1}$ The claim of the present study is that the "master subject" of Lewis's literary works was a similar cultural divide, which I refer to as the modern kulturkampf or "culture war" (the English translation of kulturkampf), ${ }^{2}$ and which may be most simply described as the sharp, politicized cultural division between the Old and the New in the modern world. ${ }^{3}$ Lewis's confrontation with the kulturkampf, the parameters of which he was constantly redefining, guided his rhetorical strategies and the construction of his authorial persona, especially in his employment of reactionary ideas and rhetoric. This study examines the development of Lewis's vision of the kulturkampf in his polemical works and in the fiction in which his polemical voice and authorial persona are most apparent, from his seminal inter-war writings to his radical change in perspective in the last two completed books of the unfinished Human Age tetralogy.

The purpose of Lewis's engagement with the kulturkampf, I argue, was threefold. First, it allowed him to formulate, through an engagement with battling orthodoxies, a strategy of action or "politics of the intellect" devoted to the protection of what Alan Munton has referred to as the Lewisian "artist-intellectual." Thus, the kulturkampf

\footnotetext{
${ }^{1}$ Lewis, The Lion and the Fox, 11.

${ }^{2}$ The term "culture war" is cited and defined later in this chapter.

${ }^{3}$ Throughout this study, I capitalize the first letters of Old and New, and Right and Left, when using these words in the context of kulturkampf rhetoric.

${ }^{4}$ The term "artist-intellectual" is also used by Alan Munton in his 1976 dissertation on Lewis. Munton, "Wyndham Lewis: the relation between the theory and the fiction, from his earliest writings to $1941, " 35$.
} 
provided the material for the construction of a complex and multifaceted form of politics "beyond action and reaction," the goal of which was the creation of a future "political equilibrium" in which artist-intellectuals and the masses would be able to coexist in peace. ${ }^{5}$ Second, it allowed him to harness the literary and political violence of others as a means of creating confusion and controversy. Lewis's writings, especially when placed in relation to their reception by his detractors and supporters, can be read as perverse, publicity-generating maneuvers in the kulturkampf. Third, Lewis's engagement with the kulturkampf functioned as a means of expanding the political consciousness of the average middle-class Briton. There is a unique brand of evangelism present in many of Lewis's polemical works; he seeks to rescue the British national consciousness from its culturally limited conception of the kulturkampf, and replace it with a more universal and cosmopolitan conception of politics. His ideal reader, in many cases, is the intelligent but unreflective "general educated person"6 whom he converts to his view by disassembling the popular kulturkampf and revealing the parameters of a broader, pan-European, or even global, transition occurring behind the scenes. The ultimate goal of such evangelism is to educate the attentive reader into becoming, like Lewis, a political free radical-a disruptive element in a highly politicized cultural environment.

\footnotetext{
${ }^{5}$ The phrase "beyond action and reaction" is the title of the last section of The Art of Being Ruled, 355-75. Lewis uses the term "political equilibrium" in The Art of Being Ruled, 325.

${ }^{6}$ Lewis, Time and Western Man, 451.
} 
The term kulturkampf was not used by Lewis himself, although it has been used before, in passing, in Lewis criticism. ${ }^{7}$ The translation of the term as "culture war" has entered common parlance over the last two decades thanks in part to James Davison Hunter's landmark study, Culture Wars: The Struggle to Define America (1991). Although kulturkampf has its terminological roots in Otto von Bismarck's battle against Roman Catholic hegemony in Germany in the late nineteenth century, ${ }^{8}$ it may be used to describe any fundamental cultural divide within a particular society or civilization. Lewis's depictions of the kulturkampf, of course, contain echoes of kulturkampfen of the past, all of which occurred during what Lewis refers to in The Lion and the Fox as "periods of transition." The older periods of transition to which Lewis commonly makes reference are the Enlightenment, the Reformation, the Renaissance, and the rise of Christianity, but the cultural divide that is perhaps most relevant as a precursor in this context is the quarrel of the ancients and the moderns in seventeenth-century France, the central debate of which was immortalized in Jonathan Swift's The Battle of the Books (1704). In his editorial notes for The Enemy no. 2 (1927), Lewis invokes Swift when noting the use and misuse of such terms as "rebel" and "reactionary" in the twentieth century. He makes the following suggestion:

In the Battle of the Books, of the seventeenth century, a parallel confusion reigned; if you are anxious to clarify your vision for these present disputes, that is a good paradigm. You can practice your eye with that. There you have the

\footnotetext{
7n "The Metamorphoses of Wyndham Lewis's The Human Age: Medium, Intertextuality, Genre," Peter L. Caracciolo uses the term kulturkampf in describing the activities of the European postWWI avant-garde. Caracciolo, "The Metamorphosis of Wyndham Lewis's The Human Age," 265. ${ }^{8}$ The term was coined by Rudolf Virchow. Waller, Bismarck, 56.

${ }^{9}$ Lewis, The Lion and the Fox, 84.
} 
extreme "Modern," and the extreme "Classicist," as you have to-day, and the nicest and most elaborate mixtures. The issues in that "Battle," if you make these necessary allowances for the widening of the scene, and the peculiar and novel forces now at work, were the same as to-day. ${ }^{10}$

Like the historical Battle of the Books, or like the American academic culture-war ignited by Allan Bloom's The Closing of the American Mind (1987), the kulturkampf that Lewis delineates often seems a purely literary or intellectualist debate, but as French author Julien Benda, one of Lewis's few literary role-models, makes clear in The Treason of the Intellectuals (1927), a prominent characteristic of twentieth-century intellectualism is that it aims to have a direct and pervasive influence on society. Such was certainly the case when Lewis was writing.

Hunter uses a Gramscian model to describe the ongoing American culture-war, and this model, if its Marxist assumptions are not stressed, is applicable to the kulturkampf of Lewis's time. Hunter refers to the American culture-war as a public struggle for hegemony between "orthodox" and "progressive" systems of thought and their supporters (which, as Hunter acknowledges, recalls the Gramscian idea of the conflict between "traditional" and "organic" intellectuals). ${ }^{11}$ For Hunter, "this struggle is not between those who sincerely advocate 'truth' and those who either unwittingly or cynically pursue misrepresentations. ... Rather, this dispute is between groups who hold fundamentally different views of the world." 12 Hunter's conception of the culture war as

${ }^{10}$ Lewis, "Editorial Notes," xxxix.

${ }^{11}$ Hunter, Culture Wars, 43-44, 61.

${ }^{12}$ Ibid., 63. 
a battle between essentially irreconcilable "views of the world" is accurate, but, in Lewis's case, it is more useful to describe the kulturkampf as a battle of orthodoxies, rather than a battle between the orthodox and the progressive. Lewis was sensitive to the potential for oppression inherent in long-standing orthodoxies, such as that of the Catholic Church, but it was also his opinion that Marxism and Bergsonism, for example, represented equally rigid orthodoxies, possessing the same potential to enslave the personality and the intellect.

For the purposes of this study, I propose the following as a working definition of kulturkampf. The term refers to a fundamental schism within a society caused by the politicization of that society's culture. At its most extreme, this politicization extends into every cultural domain, encompassing both the intellectual and artistic elite as well as those at the bottom of the socio-cultural ladder. Malcolm Muggeridge captures the allpervasiveness of this phenomenon when describing the cultural landscape of $1930 \mathrm{~s}$ England (although he sees this battle as being specifically related to the philosophy of romantic materialism):

It [the multitude of cultural conflicts in the modern world] expresses a deep cleavage of opinion, a deep discord between two expressions of the same spirit of romantic materialism-a Brave New World and a Brave Old World facing one another and menacingly flourishing the same weapons. More and more this conflict came to provide the underlying pattern of thought, whether in politics, literature or religion. It became an obsession from which no one was wholly immune, creeping into novels, plays, poems, literary criticism, sermons, lectures, conversation, films, music-hall turns. Spain provided an actual battleground 
where some shed their blood, undergraduates breaking off their studies to man machine-guns; and in the ideological fray all could join everywhere. ${ }^{13}$

As Muggeridge suggests in his description of the conflict as one between a "Brave New World" and a "Brave Old World," the dichotomy that the kulturkampf can be reduced to is that of the Old versus the New. Any one kulturkampf may exist in tandem with a number of other kulturkampfen, but there is a tendency for these to consolidate into the fundamental Old/New division, especially as the level of politicization intensifies. When a kulturkampf reaches a point of maximum intensity, the result is revolution or civil war.

My definition of kulturkampf draws upon the political philosophy of Carl Schmitt, the controversial German political philosopher, and unrepentant Nazi, whose thought has been resuscitated and critiqued by, among others, Jacques Derrida. ${ }^{14}$ Specifically, I have given the term "political" a meaning derived from Schmitt's famous 1932 treatise, The Concept of the Political. In that work, Schmitt seeks to determine the central dichotomy underlying the political itself. His conclusion is that "the specific political distinction to which political actions and motives can be reduced is that between friend and enemy."15 The idea of the enemy upon which this dichotomy is founded is, according to Schmitt, dependent upon "the ever present possibility of combat." ${ }^{.16}$ Thus, the friend/enemy distinction must always allow for the possibility of violent battle, even if it is unlikely to occur.

\footnotetext{
${ }^{13}$ Muggeridge, The Thirties, 45-6.

${ }^{14}$ Schmitt's ideas are examined at length in Derrida's Politics of Friendship (1994).

${ }^{15}$ Schmitt, The Concept of the Political, 26.

${ }^{16}$ Ibid., 32.
} 
This does not, however, mean that only states or armed insurgent factions can be considered political entities, for as Schmitt notes, "Every religious, moral, economic, ethical, or other antithesis transforms into a political one if it is sufficiently strong to group human beings effectively according to friend and enemy."17 $\mathrm{Schmitt's} \mathrm{definition}$ helps to illuminate further the mechanics of the kulturkampf: the kulturkampf occurs when the political (or the friend/enemy distinction) enters the domestic realm (or the internal realm of the nation-state or other political unit) and attaches itself to other aspects of human life, including religion, art, education, work, and family life. It fuses with the division between the Old and the New, and transforms a period of transition into a sharply dichotomized, and potentially violent, conflict between the past and the future.

Lewis and Schmitt conceptualized the political in similar ways, even if the cultural contexts in which they were writing differed significantly. ${ }^{18}$ While it is unlikely that Lewis ever read Schmitt, Schmitt certainly read Lewis, or at least Lewis's major work of political philosophy, The Art of Being Ruled (1926). In a footnote to the 1926 edition of The Crisis of Parliamentary Democracy, Schmitt praises The Art of Being Ruled and notes his agreement with Lewis's appraisal of Georges Sorel as "the key to all contemporary political thought."19

\footnotetext{
${ }^{17}$ Schmitt, The Concept of the Political, 37.

${ }^{18}$ The name of Schmitt has arisen very infrequently in Lewis criticism-tangentially in the work of Philip Head and apparently in a conference paper by Tyrus Miller-and the similarity between the two thinkers has never been explored in any detail. In his collection of essays, Some Enemy FightTalk: Aspects of Wyndham Lewis on Art and Society, Philip Head mentions Schmitt's comments on Lewis in passing in "The Tyro and the Commissar" and briefly compares Schmitt's conception of the political with that of Lewis in "Ideology, Utopia, Myth." 12-13, 46-47. According to the University of Sussex Bulletin of February 27, 1998, Tyrus Miller was scheduled to deliver a paper entitled "Modernist allegory as an art of being ruled: Wyndham Lewis, Carl Schmitt, and the liquidation of cultural autonomy" as part of an English Graduate Colloquium on March 4, 1998 at the University of Sussex.

${ }^{19}$ Schmitt, The Crisis of Parliamentary Democracy, 88n. Lewis, The Art of Being Ruled, 119.
} 
Lewis and Schmitt both believed that parliamentary democracy, which seeks to free society from violent conflict through discussion, compromise, and the protection of individual rights, was incapable of protecting the nation-state from the force of twentiethcentury mass-democracy, which is founded upon the absolute value of the will of the people. The undermining of the nation-state by the tides of mass-democracy, in their view, creates a situation in which the political (or in Schmitt's terminology, the friend/enemy distinction) ceases to be solely the concern of the state. Mass movements, according to Schmitt, have a political force of their own with the potential to set countrymen against each other and extend across national boundaries; communism, for example, creates an international political divide that transcends, and thus bisects, the traditional nation-state..$^{20}$

The solutions that Lewis and Schmitt sought as a means of correcting the uncontrolled proliferation of the political differ greatly. Schmitt thought that the solution to twentieth-century political instability lay in the restoration of the nation-state as the primary political unit in European life, which would serve as a brake on both the slippage of the political outside its proper domain and on liberal attempts to neutralize the political itself. ${ }^{21}$ Lewis, in contrast, sought to remove himself from the friend/enemy division of the political, largely because his experience in World War I instilled in him an abhorrence of violence. Instead, he waged war on politics in the name of the intellect — something he believed was the domain of only a small minority of people. Lewis's war on politics, I assert, was not a political act according to Schmittean theory,

\footnotetext{
${ }^{20}$ Schmitt, The Concept of the Political, 74.

${ }^{21}$ Ibid., 70-73, 78-79.
} 
as Lewis was speaking for a group (namely the artist-intellectuals) that he envisioned as being incapable of engaging in physical combat and unwilling to take hold of the reigns of state power in the unlikely event of victory.

True artist-intellectuals, for Lewis, are individualistic by default, as group orthodoxy makes intellectual freedom an impossibility. Thus, the artist-intellectual must avoid becoming trapped within any rigid friend/enemy division; he must participate in the kulturkampf without making ideological commitments. Lewis heeded his own advice, and after his Vorticist period he refused to align himself with a group of "friends" in opposition to another group of "enemies." In the guise of his evolving authorial persona, he fluctuated between two positions that escape the friend/enemy dichotomy: enemy-ofall and friend-of-all. Lewis's late-1920s "Enemy" persona is the most obvious example of his role as enemy-of-all, but he was equally fond of presenting himself as a friendly advocate of political moderation, as in his gesture of peace towards Germany in Hitler (1931) and his interactions with the British middle-class in Rotting Hill (1951). Lewis's personal kulturkampf, on behalf of the intellect, was thus unpolitical despite the seemingly political dichotomy it created. As a result of his unwillingness to become part of a larger political entity, he was forced to act alone- to make himself an outsider and resolute non-partisan.

As a response to the political pressure generated by the kulturkampf, Lewis made it his mission as a writer to articulate the principles of what he referred to in The Art of Being Ruled (1926) as "the politics of the intellect,"22 and this concept requires further

\footnotetext{
${ }^{22}$ Lewis, The Art of Being Ruled, 373-75.
} 
elaboration. As noted above, the politics of the intellect are a form of personal politics, and do not demand the kind of group solidarity required to be defined as political in the Schmittean sense. In The Art of Being Ruled, Lewis writes, "The life of the intelligence is the very incarnation of freedom: where it is dogmatic and harsh it is impure; where it is too political it is impure," and he envisions a community of intellectuals as consisting ideally of "individuals possessing no concerted and lawless power, coming indifferently from all classes, and living simply among other people." 23 The "politics of the intellect" are simply the means by which this ideal may be protected, and one way Lewis practiced this form of politics was by revealing and critiquing all those cultural forces that were potentially harmful to the intellect.

In his designation of the intellectual community as a social group worthy of special attention and protection, Lewis found a kindred spirit in the French writer Julien Benda, author of The Treason of the Intellectuals (1927). Benda uses the term clerc rather than intellectual in order to invoke the idea of an intellectual clerisy, and defines the clercs as "all those whose activity essentially is not the pursuit of practical aims, all those who seek their joy in the practice of an art or a science or metaphysical speculation, in short in the possession of non-material advantages, and hence in a certain manner say: 'My kingdom is not of this world." ${ }^{24}$ According to Benda, before the late-nineteenth century, the clercs constituted "another, essentially distinct humanity," and, like Lewis, he lamented the disintegration of this distinction. ${ }^{25}$

\footnotetext{
${ }^{23}$ Ibid., 374.

${ }^{24}$ Benda, The Treason of the Intellectuals, 43.

${ }^{25}$ Ibid., 43.
} 
Both Lewis and Benda strenuously objected to any committed participation of the intellectual in the world of partisan moralism or politics. Intellectuals, for example, who use their research as a means of justifying political theories or movements (from Marxist materialism to Maurrasian ultra-nationalism) would be, in Benda's language, committing intellectual treason. This is not to say, however, that Benda and Lewis thought that clercs should refrain from expressing political opinions. Ray Nichols, in his study of Benda's career, writes:

Although he [Benda] had said that he valued the pure thinker most, he also had allowed that the clerc could be a moralist. ... He could enter into intellectual action and still be faithful to that ideal, so long as those causes he defended were not realist. He could even err on occasion, by becoming involved with political passion, and not lose his title of true clerc, so long as he did not proceed to live his errors or to defend them as appropriate to his calling. ${ }^{26}$

The same might be said of Lewis-who certainly did express political opinions-although Lewis's "politics of the intellect" are more radical than Benda's clerkly ethics in that Lewis places greater stress on the autonomy of the intellect. In an oft-quoted passage from "The Diabolical Principle" (1931), Lewis writes, "I advance the strange claim (as my private Bill of Rights) to act and to think non-politically in everything, in complete detachment from all the intolerant watchwords and formulas by which we are beset. ${ }^{927}$ For both writers, the human intellect was something sacred; in life, it occupied a sphere of its own that had to be defended from attacks from the larger spheres of politics and

\footnotetext{
${ }^{26}$ Nichols, Treason, Tradition, and the Intellectual, 121-22.

${ }^{27}$ Lewis, "The Diabolical Principle," 38.
} 
religion. Thus, the phenomenon of the kulturkampf constitutes a grave threat to the clerkly life because it demands political commitment, rather than political opinion. Those who fully participate in the kulturkampf reject the idea of a non-partisan perspective, for being cultural combatants, they see their enemies as, at best, the dupes of a false ideology.

One way that Lewis engaged with the kulturkampf was through the literary representation of its participants. Central to Lewis's literary representations of the kulturkampf are those personalities, both fictional and non-fictional, who function as archetypes of either "action" or "reaction," 28 or as conflicted hybrids of both. Lewis always strives to reveal the political machinations that govern the behaviour of the figures he describes, but he generally refrains from judging according to moral criteria, a stance justified by his theory of "non-moral" satire. ${ }^{29}$ In a chapter of The Mysterious Mr. Bull (1938) entitled "Satire a Combat Between Opposite Forces," Lewis calls for a return to non-moral satire: "Satire is, as an historic form, the artistic battleground of the Good and the Bad. In its origins it was not moralist. The Christian made it that. It was the battle of Light and of Dark; or actually of White and of Black." ${ }^{30}$ Lewis's characters, whether they be the imaginary constructions of his fiction or the satirical portraits found in his criticism, tend to embody either the White or the Black, or a conflicted admixture of both extremes.

\footnotetext{
${ }^{28}$ Anne Quéma has described Lewis's method in this regard as a type of prosopopoeia. Quéma, The Agon of Modernism, 67.

${ }^{29}$ See Lewis, Men Without Art, 85-93

${ }^{30}$ Lewis, The Mysterious Mr. Bull, 142.
} 
Lewis himself did not identify with the orthodox partisans of either the White or the Black, but with the unorthodox thinkers who functioned as independent combatants. Two of the most important of these thinkers were P.J. Proudhon and Georges Sorel, both French socialists who adopted radically unorthodox approaches in their analyses of cultural conflict. Proudhon was known for his focus on irreconcilable social and economic contradictions and his "man of paradox" public persona. ${ }^{31}$ Sorel, who absorbed and developed many of Proudhon's ideas, made extensive use in his writing of what he called the "diremptive" method, ${ }^{32}$ which involves disassembling ideologies and sorting, comparing, and balancing their parts. Lewis's use of both Proudhon's analysis of contradiction and Sorel's diremptive method allowed him to insert himself into the kulturkampf as an uncommitted critic and provocateur, defying the norms of British political discourse, fueling controversy through the subtle use of intentional selfmisrepresentation, and reinforcing his position as a political outsider.

Underneath Lewis's attempts to appear non-partisan, one can detect the outlines of a continually evolving, mixed ideology that at different times incorporates elements of anarchism, social democracy, fascism, and even political Catholicism. Although I attempt to trace the development of Lewis's unstable politics in this study, I do not seek to affix any permanent political labels; to do so would replicate a mistake that many of his critics have made. The search for the "real Lewis" and his core political doctrine always comes into conflict with the game of evasion that Lewis plays with his readers. His writings — even his most minor and polemical — are built of layers of rhetorical irony

${ }^{31}$ Qtd. in Woodcock, "A Personal Preface," xiii.

${ }^{32}$ Sorel, Reflections on Violence, 259. 
arranged in the manner of his vorticist paintings: the centre of the vortex is constantly receding, but nevertheless possesses a centripetal force. ${ }^{33}$ Lewis knew that all his writings, especially those of the 1930 s, were subject to intense political scrutiny by both the Left and the Right, insofar as the ideological analysis of art was a particularly dominant form of criticism during much of his career. He reveled in taunting his audience, forcing them to stretch their powers of analysis to the breaking-point. Reed Way Dasenbrock captures this characteristic of Lewis's work in his afterword to The Art of Being Ruled (1926): "It is really remarkably difficult for most of the book to define Lewis's position on the issues he is discussing. He constantly judges the phenomena he discusses, but he does so from a shifting, mobile perspective." ${ }^{94}$ To affix a political label on Lewis requires that one ignore the profound implications of his "shifting, mobile perspective," and contradicts his explicitly stated political intentions.

This is not to say that one should always take Lewis at face-value; in my analysis I attempt to strike a balance between adherence to Lewis's explicit statements of intent on one hand, and speculation as to his implicit, hidden, or sublimated motives, on the other. The authorial intentions that are suggested in his texts, of course, are not those of Lewis himself, but of the authorial persona, or, in some cases, the implied author of his

\footnotetext{
${ }^{33}$ The idea that Lewis used contradiction as a means of evasion is recognized by a number of Lewis critics. For example, in describing the texts discussed in his study Near Miss: $A$ Study of Wyndham Lewis (1909-1930), Antonio M. Feijó states that "A capacity to entertain antinomies without striving to arrest them in any apparent synthesis makes these texts peculiarly unstable. The presence of so many insidious contradictions in Lewis's corpus is, in fact, a deliberately evasive procedure." Feijó, 4. For a full-length study of Lewis's use of contradiction, see Philip Head's Engaging the Enemy: The Gentle Art of Contradiction in the Work of Wyndham Lewis (2001). Head, unfortunately, does not state his argument clearly, despite his extensive knowledge of Lewis's works, and never manages to create a convincing model of a Lewisian dialectic. Instead, he draws the reader through a maze of continental philosophy, much of which is only tangentially related to Lewis's thought.

${ }^{34}$ Dasenbrock, Afterword, 436.
} 
writings, ${ }^{35}$ who is nevertheless similar to the biographical Lewis in many respects. Lewis took pains to hide the details of his private life from public view and at the same time fostered a sometimes outlandish public image, to the extent that knowing his particular guise at any given period is crucial to understanding his writings from the period in question. ${ }^{36}$ Also, just as an authorial persona or implied author exists in Lewis's works, there exist implied readers (as has been noted by Andrzej Gąsiorek), ${ }^{37}$ who through reading Lewis are either provoked into partisan rage or led out of the kulturkampf, away from orthodoxy, and into a new realm of intellectual autonomy and freedom. Such implied readers are, of course, a construct developed by Lewis, and may or may not bear any relationship to the actual reading public of Lewis's time.

As my approach to Lewis suggests, I believe that considerations of authorial intention are justified, not only in relation to Lewis, but in literary studies in general. Dasenbrock provides an extended analysis of the topic in Truth and Consequences: Intentions, Conventions, and the New Thematics (2001). In that work, which does not deal with Lewis, he criticizes the prevalence of conventionalism and anti-intentionalism in the literary criticism of the last few decades, offering instead a new intentionalist approach to the study of literature rooted in the analytic philosophy of Donald Davidson:

\footnotetext{
${ }^{35}$ The term "implied author" is commonly associated with Wayne C. Booth's The Rhetoric of Fiction (1961). Describing the author of any literary work, Booth states that "As he writes, he creates not simply an ideal, impersonal 'man in general' but an implied version of 'himself' that is different from the implied authors we meet in other men's works. ... However impersonal he may try to be, his reader will inevitably construct a picture of the official scribe who writes in this manner-and of course that official scribe will never be neutral toward all values. Our reactions to his various commitments, secret or overt, will help to determine our response to the work." Booth, The Rhetoric of Fiction, 70-71. The term "official scribe" is borrowed from Jessamyn West. ${ }^{36}$ See "Mr. Wyndham Lewis: 'Personal-Appearance Artist"” in Lewis, Men Without Art, 95.

${ }^{37}$ Gąsiorek, Wyndham Lewis and Modernism, 6.
} 
Anyone wishing to recover a sense of the social power of literature or writing in general needs to be able to recover a sense of the human agents who act in society by means of that writing. The criticism that has attempted to recover the social nature of literature over the past generation has often been rendered ineffectual in that act of recovery because of its refusal to adopt an intentionalist understanding of the very human agents it attempted to understand. Only if we grant that texts are tethered to social context at their point of origin by authorial intentions can we escape the tendency to view texts in isolation from the social world. And discussion of action presupposes actors. ${ }^{38}$

I will not enter into an extended examination of Dasenbrock's approach, but it is in the spirit of his appropriation of Davidson that I view the idea of intentionality in Lewis's work. A model of literary intention that positions Lewis as being in constant dialectical conflict with the cultural landscape of his time, and not merely its product, generates considerations of context and reception that allow for speculation regarding his ideological tendencies, but at the same time does not doom Lewis to being simply representative of a particular set of discourses.

Misinterpretations of Lewis's authorial intentions and resistance to the idea of authorial intention itself are perhaps partly responsible for the wide variety of interpretations to which Lewis's work has been subject, especially in relation to Lewis's alleged fascism and anti-Semitism. One example of the outright dismissal of Lewis's

\footnotetext{
${ }^{38}$ Dasenbrock, Truth and Consequences, 175.
} 
explicitly stated intentions, resulting in a one-sided attack on his character, is an article by Geoffrey Wagner entitled "The Fascist Mentality-Wyndham Lewis," which appeared in a 1968 issue of The Wiener Library Bulletin, "An International Review published by The Wiener Library [a Holocaust memorial museum] in conjunction with the AntiDefamation League of B'nai Brith, New York." Wagner writes that "Lewis was a selfcontradictory figure and the most charitable summary of his many evasive statements about his own politics might be to regard them as techniques for concealment, similar to the 'masks' of Yeats or Pound." 39 It would seem that this conspiratorial view of Lewis is the "most charitable" view possible only because Wagner has already presumed Lewis guilty of being a fascist. Wagner states, without providing clear evidence, that "Lewis's thought seems to have been Fascist from the start, almost one might say avant le jour."40 Thus, Lewis's writings after the beginning of World War II, and specifically America, I Presume (1940) and The Vulgar Streak (1941), "reinforce the feeling that he was urgently rewriting himself and emphasize, in a way that is inevitably repellent, the ineffectualness and self-hatred of the creed he had so briefly espoused." ${ }^{941}$ Regarding Lewis's attitudes towards the Jews, Wagner boldly asserts that "in such cases Lewis gave up thinking. He was hating-as nearly all his work on Jewish aspiration shows, from that on Gertrude Stein to his random comments on Einstein." ${ }^{, 42}$ Despite Wagner's claims, one need only open Time and Western Man (1927) to see that Lewis's antagonism towards Stein is based upon the flaws in her work and not her race, and that it is popular

\footnotetext{
${ }^{39}$ Wagner, "The Fascist Mentality," 35.

${ }^{40}$ Ibid., 36.

${ }^{41}$ Ibid., 36.

${ }^{42}$ Ibid., 37.
} 
interpretations of.Einstein's thought, and not Einstein himself, or even the specifics of his thought, that Lewis critiques. ${ }^{43}$ In that same work, Lewis's "hate" is directed at a number of other, non-Jewish artists and thinkers as well, including his friends James Joyce and Ezra Pound, and even the literary figurehead of early-twentieth-century German nationalism, Oswald Spengler. Wagner also seems to forget that Lewis held some Jewish thinkers and artists, such as Julien Benda and sculptor Jacob Epstein, in very high regard. It is distressing to find Wagner, who wrote one of the most insightful, if flawed, early books on Lewis, conducting such a biased analysis in a publication with the potential to influence Jewish opinion throughout the world. Lewis may have harboured anti-Semitic ideas, but Wagner does not provide proof-he merely accuses. Unfortunately, the Wagner article is not unique, and the presentation of Lewis as an unambiguous fascist and antiSemite occurs often in Lewis criticism. Most notably, Fredric Jameson has explored what he considers to be the "proto-fascist" discourses permeating Lewis's work, and David Ayers claims that Lewis's work consistently displays a deeply rooted anti-Semitism. ${ }^{44}$ These accusations, however, have been repudiated by Alan Munton and Paul Edwards, respectively. ${ }^{45}$

Those critics who give weight to Lewis's explicitly stated intentions tend to view him as something more than a mere fascist, and place his works outside of the traditional

\footnotetext{
${ }^{43}$ Lewis criticizes, in particular, the vulgarization of the theory of relativity by those such as Einstein's enthusiastic confidante, the writer Alexander Moszkowski. Lewis, Time and Western Man, 140-43.

${ }^{44}$ See Jameson, Fables of Aggression, 15-16; and Ayers, 15.

${ }^{45}$ Alan Munton's exposure of the flaws in Jameson's book can be found in Blast 3, published in 1984. Munton, "Fredric Jameson," 345-51. Paul Edwards provides a severe criticism of Ayers's book in a Times Literary Supplement review from January 1, 1993. Edwards, "Self and Not-self," 22.
} 
bounds of fascist discourse. Alan Munton, in particular, has become a staunch defender of Lewis against accusations of fascism, and in his articles and reviews emphasizes the revolutionary tendencies in Lewis's thought, and particularly Lewis's interest in Proudhon. ${ }^{46}$ The repudiation of the idea of Lewis as a fascist is a prominent theme in all of Munton's writings, from his 1976 dissertation to his most recent publications, including a 2006 article entitled "Wyndham Lewis: From Proudhon to Hitler (and back): the Strange Political Journey of Wyndham Lewis," which he describes as "a contribution to the challenge to the orthodox view that Lewis's work was infiltrated at every level by right-wing ideas. ${ }^{" 47}$ In that article, he states that "Recent work by Paul Edwards and Andrzej Gąsiorek has altered the critical and political landscape [of Lewis criticism], substantially and permanently." $" 48$ The work he is referring to includes Edwards's Wyndham Lewis: Painter and Writer (2000) and Gąsiorek's Wyndham Lewis and Modernism (2004), both of which provide comprehensive overviews of Lewis's career and, in part, seek to counter the idea that Lewis was essentially a thinker of the Right. In the acerbic “"Imputing Noxiousness': Aggression and Mutilation in Recent Lewis Criticism," Munton claims that "Lewis criticism, like no other in the study of modernism, is the arena in which critics have found that they can act out their desires," and that Lewis has become "the person about whom anything can be said."49 Munton's

\footnotetext{
${ }^{46}$ For Munton's attack on alleged misinterpretations and misrepresentations of Lewis, see “"Imputing Noxiousness': Aggression and Mutilation in Recent Lewis Criticism" and "Fantasies of Violence: The Consequences of Not Reading Wyndham Lewis." For his evaluation of Lewis's politics, see "The Politics of Wyndham Lewis" and "Wyndham Lewis: From Proudhon to Hitler (and back): the Strange Political Journey of Wyndham Lewis." His most recent writing on the subject can be found in "Wyndham Lewis Our Contemporary," the introduction to Wyndham Lewis the Radical (2007).

${ }^{47}$ Munton, "Wyndham Lewis: From Proudhon to Hitler (and back)," 28.

${ }^{48}$ Ibid., 28.

${ }^{49}$ Munton, "'Imputing Noxiousness'," 5.
} 
claim is an overstatement, as it is clear that in many cases the radical differences in interpretation that he identifies are more the result of an intentional elusiveness in Lewis's thought than symptoms of scholarly inadequacy or overt political bias on the part of Lewis scholars. While there is certainly a tendency among Lewis critics, most marked in the cases of Wagner, Jameson, and Ayers, to categorize Lewis as a thorough reactionary according to kulturkampf criteria, one wonders whether Munton might be playing the same game at times. Munton sees Lewis's politics as fluctuating between two extremes within leftist political philosophy, and claims that the "structural opposition between Marxian centralization and Proudhonian decentralization is the key to Lewis's politics." $" 50$ Thus, in Munton's view, Lewis's admiration for the British Union of Fascists, for example, is based upon his mistaken interpretation of fascism as being essentially Proudhonian. Munton explains that "[Lewis's] account of Fascism is itself a serious misrecognition, showing that Lewis had not yet understood that the forces at work in Germany and Italy-to which the British movement was an appendage-were intrinsically and necessarily large-scale, authoritarian and centralizing." ${ }^{.51}$ For Munton, then, Lewis was essentially a leftist who was attracted to fascism because it seemed, from Lewis's presumably warped perspective, to espouse the particular left-wing political philosophy that he found most appealing.

Munton's argument is strong-much stronger than Jameson's argument that Lewis was a proto-fascist-but it does not take into full account the complexity of rightist discourse in the period and why Lewis thought it worth exploring. Socialist ideas are not

\footnotetext{
${ }^{50}$ Munton, "Wyndham Lewis: From Proudhon to Hitler (and back)," 29.

${ }^{51}$ Ibid., 30.
} 
exclusively the territory of the political left, and there exist both centralist and decentralist political philosophies of the right. In fact, the political philosophy of Proudhon is notable for having inspired movements on both sides of the political spectrum. ${ }^{52}$ Arguably, it is more productive to see Lewis as responding to his vision of what constituted the kulturkampf at any given time-period than it is to affix a label to his political tendencies; Lewis fluctuates between the Old and the New (and whatever political forms those categories might take), sometimes as a means of disrupting political orthodoxies, and sometimes as a means of simply inciting controversy. Lewis found Proudhon and Sorel interesting because they also wrote from outside the conventional political spectrum, the result being that it is difficult to determine whether they were revolutionaries or reactionaries. Regarding Sorel, Lewis himself writes in The Art of Being Ruled that "He is the arch exponent of extreme action and revolutionary violence $\grave{a}$ outrance; but he expounds this sanguinary doctrine in manuals that often, by the changing of a few words, would equally serve the forces of traditional authority, and provide them with a twin evangel of demented and intolerant class-war." ${ }^{\text {53 }}$ Proudhon's thought is similar in its appeal to both traditionalists and revolutionaries, but for Lewis it is preferable to Sorel's because Proudhon seeks a creative balancing of opposites rather than apocalyptic class-war. Thus, it is perhaps because of their roots in Proudhon and Sorel that Lewis's ideas have proved to be equally attractive, or repulsive, to both the Left and the Right. One must ask whether it is for this reason, rather than because of a

\footnotetext{
${ }^{52}$ For examples of Proudhon's contributions to the development of fascist ideology, see J. Salwyn Schapiro's "Pierre Joseph Proudhon, Harbinger of Fascism."

${ }^{53}$ Lewis, The Art of Being Ruled, 119.
} 
conspiracy among the majority of academics, that Lewis has become "the person about whom anything can be said."

Munton seeks to make Lewis's work palatable to the academic left as something more than a specimen of literary fascism; my position is that Lewis's work was intended to be of value primarily to those who belong to neither the political right nor left, and that a politically partisan view of Lewis is always, to some extent, an incomplete view. For example, because of his unwillingness to see Lewis as anything other than a Proudhonian leftist, Munton is unable to place any value upon Lewis's polemics of the 1930s, an omission he can only justify by assuming that Lewis was psychologically detached from reality during the Hitler era. Munton writes that during the 1930 s, "Lewis suffered a massive ignorance of political realities, and his politics were subjective; but at least he was not consciously working in the interests of the forces represented by fascism. He was a deluded apologist, and Hitler and Count Your Dead are stupid books, not evil ones." Munton's evaluation amounts to an underestimation of Lewis's insight into the politics of the 1930s: Left Wings Over Europe, with its careful dissection of a vast array of newspaper reports describing the intricacies of European political diplomacy, provides ample proof that Lewis was acutely aware of the realities of European politics, and Hitler itself provides a detailed and informed portrait of a movement of which few people in England were more than casually aware. Because Munton sees fascism as essentially "racialist monopoly capitalism," 55 he is unable to appreciate that fascism in the 1920 s and 30s assumed many different forms before it gravitated towards the ideological behemoth

\footnotetext{
${ }^{54}$ Munton, "The Politics of Wyndham Lewis," 38.

${ }^{55}$ Ibid., 38.
} 
of orthodox Nazism in the late 1930s, which was precisely the time that Lewis became a vocal critic of both Hitlerism and anti-Semitism. It would be more accurate, and more revealing, to say that Lewis's understanding of the complexities of fascist ideology caused him to underestimate the power of fascist idolatry, as manifested in the "HitlerCult," as Lewis later called it in his 1939 book of that title. Lewis sought to look beneath what he saw as British anti-German propaganda, but did not consider the, for him, unlikely possibility that the propaganda might actually be accurate, and that the leftist view of fascism was perhaps right, even if for the wrong reasons. Only belatedly did he realize that the Nazis were exactly the kind of monsters they had been made out to be. As my overview of the debate regarding Lewis's politics suggests, the idea of "Wyndham Lewis the Radical" (which is the title of a 2007 book of Lewis criticism, edited by Carmelo Cunchillos Jaime) has recently supplanted the idea of "Wyndham Lewis the Reactionary" in modernist studies, but neither of these approaches does justice to Lewis's work. Lewis wrestled with the political spectrum in its entirety, in a continuous struggle that can be traced by examining his representations of the kulturkampf. Given that the debate over Lewis's political allegiances has not abated, and that the same rhetorical feuds have repeatedly arisen in relation to his work, I would suggest that any critic examining Lewis's politics must consider Lewis scholarship as another phase of his reception-history-one that will be necessarily influenced by politics as long as there remain strong ideological divisions in the academic community. In saying this, I do not mean to denigrate the vast amount of careful and indispensable work that has been done in Lewis studies. Important early works on Lewis include Roy Campbell's Wyndham Lewis (written in 1931 but not published until 1984), which 
provides an enthusiastic overview of Lewis's writing up to 1931; Hugh Gordon Porteus's Wyndham Lewis: A Discursive Exposition (1932), which is a foundational text for investigations into Lewis's aesthetics; Hugh Kenner's Wyndham Lewis (1954), which synthesizes many aspects of Lewis's work into an idiosyncratic portrayal of Lewis as a key modernist thinker; Wagner's Wyndham Lewis: A Portrait of the Artist as the Enemy (1957), which is notable for the connections Wagner draws between Lewis's ideas and those of the French neo-classicists; and Sheila Watson's 1964 doctoral dissertation (supervised by Marshall McLuhan) Wyndham Lewis and Expressionism (published in 2003), which is an innovative work in itself, eschewing linear argument for a McLuhanesque assemblage of short and often disconnected observations on Lewis's aesthetics. Jameson's Fables of Aggression: Wyndham Lewis, the Modernist as Fascist (1979), despite its flaws, revolutionized Lewis criticism by applying a battery of ideas drawn from critical theory to Lewis's work. Since then, interest in Lewis has grown rapidly, and important monographs on Lewis of the last twenty-five years (aside from the aforementioned works by Edwards and Gąsiorek) include Toby Avard Foshay's Wyndham Lewis and the Avant-Garde: The Politics of the Intellect (1992), which argues that Lewis practiced an essentially Nietzschean avant-gardism; Tom Normand's Wyndham Lewis the Artist: Holding the Mirror Up to Politics (1992), which examines the relationship between Lewis's painting and his politics; Daniel Schenker's Wyndham Lewis: Religion and Modernism (1992), which as its title suggests, examines some of the religious themes and ideas in Lewis's work; Vincent Sherry's Ezra Pound, Wyndham Lewis, and Radical Modernism (1993), which positions Lewis, along with Pound, as a champion of the visual over the auditory; Anne Quéma's The Agon of Modernism: 
Wyndham Lewis's Allegories, Aesthetics, and Politics (1999), which examines the allegorical dimensions of Lewis's work, using the language of psychoanalysis; and David A. Wragg's Wyndham Lewis and the Philosophy of Art in Early Modernist Britain: Creating a Political Aesthetic (2005), in which Lewis's thought is examined in relation to "enlightenment" discourse. Additionally, Philip Head, in Some Enemy Fight-Talk: Aspects of Wyndham Lewis on Art and Society (1999) and Engaging the Enemy: The Gentle Art of Contradiction in the Work of Wyndham Lewis (2001), has done a great deal to relate Lewis's thought to larger, continental philosophical debates. Many unpublished dissertations on Lewis also exist, and one that is particularly relevant to this study is Brian James Murray's "Awaiting the Apocalypse: The Later Novels and Short Stories of Percy Wyndham Lewis" (1980), which examines both Rotting Hill and The Human Age in detail and contains a chapter devoted to the influence of Catholicism on Lewis's later thought.

The present study also has some direct precursors that must be mentioned.

Although I disagree with some of Wagner's conclusions regarding Lewis's politics, I acknowledge the importance of his 1957 study. Even if his analysis is biased, Wagner is one of the few Lewis critics to have carefully examined Lewis's ties to French neoclassicism, neo-Thomism, and other varieties of twentieth-century conservatism. I am also indebted to D.G. Bridson's The Filibuster: A Study of the Political Ideas of Wyndham Lewis (1972), which offers a comprehensive overview of Lewis's political writings and provides first-hand knowledge of the cultural contexts in which they were published. Although he perhaps tries too hard to make Lewis acceptable to the political left, he provides the most exhaustive analysis that exists of what Lewis actually said in 
his political writings. Munton's work, which I have already drawn attention to, provided

fresh insights into Lewis's politics that helped inspire me to undertake this project.

Another precursor is SueEllen Campbell's The Enemy Opposite: The Outlaw Criticism of

Wyndham Lewis (1988), which offers an in-depth examination of Lewis's "Enemy"

persona, primarily in relation to Time and Western Man (1927). Campbell tends,

however, simply to catalogue specific examples of Lewis's enemy rhetoric, and talks

only vaguely about the ultimate purpose of Lewis's use of contradiction, which

is-importantly-to create a politico-cultural protective zone for the artist-intellectual. One

of her central theses is that "In each of Lewis's major statements of belief we can also see

traces of the opposite belief — in what adds up to a pervasive structure of half-hidden self-

criticism, a kind of self-deconstruction." ${ }^{, 56}$ Although this is a valid interpretation, it is

more accurate to say that these oppositions represent an internalization of kulturkampf

dialectic; ${ }^{57}$ what appears as "self-deconstruction" is actually a form of self-development

and balancing of the personality, achieved through the mental ingestion and

reconstitution of the intellectual violence of the kulturkampf.

My analysis in this study is essentially chronological and focuses on Lewis's

criticism as well as a selection of his fiction. Chapter one addresses the two works that

\footnotetext{
${ }^{56}$ Campbell, The Enemy Opposite, $\mathrm{xv}$.

${ }^{57}$ It is also misleading to align Lewis with any sort of proto-deconstructionism, which Campbell does explicitly, stating, "beneath my own arguments are the tools of structuralist and poststructuralist analysis; these are useful largely because Lewis is also himself a structuralist and a deconstructive critic." Campbell, The Enemy Opposite, xv. While Lewis's cultural analysis certainly involved the delineation of contradictions, Jacques Derrida's deconstructionism is rooted in a philosophical and linguistic tradition that would have been largely alien to Lewis. Philip Head examines the idea of Lewis-as-deconstructionist in "From Diremption to Deconstruction" in Some Enemy Fight-Talk: Aspects of Wyndham Lewis on Art and Society, and comes to the conclusion that Lewis's use of a mix of Sorelian diremption and Nietzchean criticism is distinct from, and ultimately only loosely related to, deconstructionism. Head, "From Diremption to Deconstruction," 153-158.
} 
define both Lewis's vision of the kulturkampf and his "politics of the intellect": The Lion and the Fox (1927) and The Art of Being Ruled (1926). In chapter two I analyze the rhetorical techniques Lewis used to engage with the kulturkampf, focusing on his battle with the journal transition and his second work on the "age-war," The Old Gang and the New Gang (1932), in which his evangelical aspirations are most apparent. Chapter three examines Lewis's allegedly pro-fascist polemical writings-Hitler (1931), Left Wings Over Europe (1936), and Count Your Dead: They are Alive! (1937)-arguing that they were meant to transform and rejuvenate British Toryism and explode the false kulturkampf of the Old versus the New in 1930s England. The subject of chapter four is Lewis's post-World War II criticism and the resurgence of the kulturkampf model in the stories of Rotting Hill (1951). I draw close attention to Lewis's "friend-of-all" authorial persona in Rotting Hill and his renewed interest in both conservatism and the British national consciousness after the unabashed cosmopolitan utopianism of America and Cosmic Man (1949). Chapter five addresses Lewis's radical change of perspective in the last books of the Human Age tetralogy, in which the "Black" versus "White" dichotomy of the kulturkampf is transformed into the Christian dichotomy of Heaven versus Hell or Good versus Evil, and through which Lewis implicitly declares the failure of the "politics of the intellect." In the later Human Age novels, I argue, a shift occurs in the tone and purpose of Lewis's writing from political evangelism to religious evangelism, which is reflected in a gradual shift between the genres of political satire and religious apocalypse.

My selection of texts may seem unusual or idiosyncratic, especially given that I do not examine The Revenge for Love (1937), Lewis's most famous novel, which typically figures prominently in any study of his politics. My reason for this is that I am 
seeking to provide not just a study of Lewis's politics, but a study of how he incorporated the political landscape of his time-and particularly what I have referred to as the kulturkampf-within his authorial persona. In other words, in the works I have chosen, Lewis's authorial persona itself becomes the site of an internalized representation of the kulturkampf-a phenomenon that is less apparent in those works, like The Revenge for Love, in which the characteristics of the authorial persona are difficult to discern. The two fictional works that I examine are ones in which the Lewisian authorial persona is readily apparent: many of the stories in Rotting Hill are autobiographical and feature Lewis himself as a first-person narrator, and James Pullman, in The Human Age, represents the Lewisian clerc, if not Lewis himself. Self Condemned (1954), Lewis's grueling semi-autobiographical novel describing the experience of an European intellectual in North American exile, does fit this mold, but does not deal extensively with politics, and thus I have excluded it from this study. Lewis's early years and vorticist period are not covered simply because at that time, Lewis was more of a participant in the kulturkampf than an observer of it. ${ }^{58}$

The general purpose of this study is to define the shifting parameters of the kulturkampf that Lewis describes and to analyze the interaction of Lewis's authorial

\footnotetext{
${ }^{58}$ Tyrus Miller, in a 2005 essay entitled "No Man's Land: Wyndham Lewis and Cultural Revolution," provides an analysis of Lewis's early years of artistic activity that is relevant to this study. He remarks that "Over the crucial years between about 1915 and 1925, which coincide with the most intensive period of cultural revolutionary thought in both Central and Eastern Europe, Wyndham Lewis was the figure in Britain in closest proximity to a cultural revolutionary position. It is also, therefore, not accidental that when his position begins to change under the pressure of circumstances and intensive critical reflection in the early 1920s, Lewis, more than any of his contemporaries, also becomes an explicit, articulate critic of the conceptual framework of cultural revolution. Yet Lewis, as a critic of cultural revolution, continues to occupy the cultural revolutionary position negatively from within, exploring its parameters, limitations, and implications, and turning it into his own instrument of struggle against a liberal culture that he remained convinced was justifiably disappearing." Miller, "No Man's Land," 13.
} 
persona (hereafter referred to simply as "Lewis," unless otherwise specified) with this politico-cultural landscape. Although I suggest that Lewis's tendency towards reaction stems not only from rhetorical strategy but in some cases from a genuine sympathy, I do not wish, as I have already stated, to affix another political label on Lewis. The first principle of the art of reading Lewis is to refrain from assigning Lewis a position within the kulturkampf, and to recognize that he was essentially a chronic outsider, equally fascinated and repelled by the twentieth-century kulturkampf — by both its apostles of action and its prophets of decline. 


\section{Chapter One}

Riddles of the Sphinx: The Diremption of the Kulturkampf in The Lion and the Fox and The Art of Being Ruled

The story of Lewis's estrangement from, and subsequent engagement with, the kulturkampf begins after his vorticist period of avant-garde agitation, which lasted from approximately 1914 (with the publication of $B L A S T$ ) to 1919 (with the publication of The Caliph's Design). After developing an abhorrence towards violence while serving in the Great War, ${ }^{1}$ Lewis spent the first half of the 1920 s living in reclusive near-isolation, reading, writing, and reevaluating his ideas in light of the new cultural environment emerging in post-war Europe. ${ }^{2}$ By 1925 he had completed much of what was intended to be his literary magnum opus, prospectively entitled The Man of the World. ${ }^{3}$ Instead, however, of publishing in a single volume what would have been, according to the calculations of Paul O'Keefe, over 800 pages of text, ${ }^{4}$ Lewis decided to publish its sections as separate books. It is in the first two books from this group, The Art of Being Ruled (1926) and The Lion and the Fox (1927), that Lewis discusses most elaborately his ideas regarding the nature of the political and the kulturkampf. Both contain an implicit warning to other artist-intellectuals regarding the seductive power of the political, and describe a rhetorical and analytical framework through which Lewis is able to engage with the politics of the kulturkampf without compromising his artistic and intellectual independence-a framework that functions as the foundation of much of his later work.

\footnotetext{
${ }^{1}$ See, for example, Rude Assignment, 70-71, 148.

${ }^{2}$ For information on Lewis's mysterious 1919-1925 period, see Meyers, The Enemy, 102-130.

${ }^{3}$ Ibid., 105.

${ }^{4}$ O'Keeffe, Some Sort of Genius, 259.
} 
In The Lion and the Fox, Lewis does not merely offer a new interpretation of Shakespeare's tragedies, but constructs a model of his ideal author. This ideal author is the detached artist-intellectual who observes the cultural conflicts of his time period from a non-partisan perspective, but who nevertheless enters into political dialogue from this privileged viewpoint. Lewis's vision of the artist-intellectual corresponds in many respects to Julien Benda's clerc, who is a thinker with a strong aversion to the political power-matrix, but the Lewisian clerc-as represented by Shakespeare-is intensely individualistic, almost to the point of being solipsistic or nihilistic. He strives for a comprehensive view of the cultural whole, taking account of all cultural contradictions-and while this striving may appear to stem from a doctrine of objective "impersonality," it reveals upon closer inspection a form of individualism that corresponds with his outsider status. By mentally ingesting and then reconstituting the "not-self," or the universe outside the self, the Lewisian clerc positions himself as a unique creative force, and as the enemy of society at large.

In The Art of Being Ruled, Lewis attempts to emulate the model of the artistintellectual developed in The Lion and the Fox. Like Shakespeare acting as a "mirror" upon which cultural conflict is reflected, Lewis conducts his political analyses by describing in detail the various cultural battles of his time-period. He then dissects these kulturkampfen by subjecting them to a process of Sorelian "diremption," his goal being to subdue the warring factions by disrupting the friend/enemy divisions that divide them, and bring them into a state of Proudhonian "political equilibrium." In addition, he

\footnotetext{
${ }^{5}$ The term diremption is cited and defined later in this chapter.

${ }^{6}$ The idea of "political equilibrium" is cited and defined later in this chapter.
} 
simultaneously performs an act of rhetorical sleight-of-hand designed to frustrate both ideologically-driven critics and political partisans looking for literary support. When analyzing a particular socio-political "war" or friend/enemy division (to use the terminology of Carl Schmitt), Lewis criticizes one of the warring factions, knowing that in positioning himself as the enemy of one he will appear to be the friend of the other; then, in order to avoid accusations of partisanship, he criticizes the other faction, and this pattern continues, with Lewis playing role of enemy-of-all.

The Lion and the Fox, subtitled The rôle of the hero in the plays of Shakespeare, is ostensibly a study of the influence of Machiavellian thought on Shakespeare's tragedies, but in Rude Assignment, Lewis describes the work, which was written before The Art of Being Ruled but not published until 1927, as his "first political book." It has certainly been read as a political book by critics and scholars, but interpretations of its political message vary widely and often overlook the function it was meant to have in the context of Lewis's oeuvre. ${ }^{8}$ Through his reading of Shakespeare, Lewis provides a

\footnotetext{
${ }^{7}$ Lewis, Rude Assignment, 174.

${ }^{8}$ Some of the contemporary reviews of The Lion and the Fox express admiration along with a certain bewilderment regarding Lewis's intentions, such as R.P. Blackmur's review of the book in a 1927 issue of The Hound \& Horn. Blackmur captures the essence of Lewis's confusing but invigorating method of argument: "Mr. Lewis is a random writer, a disorderly, almost at times a dishevelled writer. There are two or three or many orders of thinking attempting simultaneous expression; and each 'order' subdivides itself many times. The issue is scandalous; ideas seize Lewis, and his reader, by the throat; one feels physically enlightened, and sometimes muscularly damaged. Mr. Lewis' essays are violent notebooks for masterpieces." Blackmur, 43.

The "disorderly" writing style that Blackmur identifies in The Lion and the Fox has allowed some critics to misinterpret or misrepresent Lewis's arguments-sometimes radically. Sharon Stockton, for instance, in "Aesthetics, Politics, and the Staging of the World: Wyndham Lewis and the Renaissance," sees in Lewis's evaluation of Shakespeare in The Lion and the Fox an implicit support of Hitlerism and genocide avant la lettre: "Lewis's reconstructions of the Renaissance and of Shakespeare in particular ... open directly onto the means by which Lewis feels justified in celebrating in 1931 Adolph Hitler's rise to power. For Lewis, the conflation of one type of rhetoric with another allows him to think that genocide, in effect, is on the same
} 
conceptual framework through which his own future work may be read. Shakespeare emerges as the epitome of the artist-intellectual or Lewisian clerc, and every general observation that Lewis makes regarding Shakespeare applies equally well to the authorial persona or implied author of most of Lewis's subsequent writings.

The title of The Lion and the Fox refers to the two personality-types that Niccolò Machiavelli famously advised the perfect ruler to imitate. ${ }^{9}$ The lion, in the Machiavellian scheme, represents virtue, bravery, and ferocity, while the fox represents practicality, self-interest, and craftiness. For Lewis, this lion/fox dichotomy is a reflection of the culture of the English Renaissance, which was characterized by a fundamental divide between an old medieval worldview and an emerging modern worldview. The deterioration of the medieval worldview facilitated the vulgarization, legitimization, and systematization of the qualities of the fox in the cultural archetype of the "man of the world" or "[the] man who is himself small and weak, but who has acquired, who lives in the midst of, a powerful defensive machinery."10 Lewis suggests that the representation

ontological plane with dramatic tragedy." Stockton, 510. It is difficult to imagine how Lewis could have foreseen the Holocaust from the 1931 vantage point of Hitler, let alone from the mid-1920s vantage point of The Lion and the Fox, or to believe that he retrospectively justified the murder of millions through a particular reading of Shakespeare. For an even-handed discussion of The Lion and the Fox, see Edwards, Wyndham Lewis: Painter and Writer, 293-98.

${ }^{9}$ Lewis argues that the Machiavellian metaphor of the Lion and the Fox was a dominant trope in English culture during Shakespeare's time, although he only offers one example, taken from Thomas Nashe's The Unfortunate Traveller (1594), which also appears as an epigraph to the book. Lewis, The Lion and the Fox, 67-68. The quotation is as follows: "Want cannot be withstood; men can do no more than they can do. What remained then but the fox's case must help when the lion's skin is out at the elbows." Nashe, The Unfortunate Traveller, 255. Nashe's phrase, "the fox's case," became the title of a 1925 article by Lewis that was later incorporated into The Lion and the Fox.

${ }^{10}$ Lewis, The Lion and the Fox, 187. 
of this cultural divide, in all its manifestations, is the "master-subject" of Shakespeare's work: ${ }^{11}$

This [master subject] was ... immediately and historically, the reflection of the struggle between chivalry, "celtism," christian mysticism, on the one hand, and the "scientific spirit" of the renaissance mind and of the modern world on the other. It was the struggle that gave such force and point to the work of Cervantes and Rabelais. And Shakespeare was more positivist than Cervantes, and less so I think than Rabelais: his was a mean position, but into this mean he gathered the excesses of his time as well. That is why with all his measure he had so much force. $^{12}$

This type of historical shift or "struggle" is what Lewis refers to in this and other works as a "period of transition," a term he borrows from Pasquale Villari's Life and Times of Niccolò Machiavelli (1877-82). ${ }^{13}$ In his chapter on "Periods of Transition" in The Lion and the Fox, Lewis paraphrases Villari's portrayal of the culture of the Renaissance: The abrupt translation of an entire society from one set of values to another, from the values of the feudal commune to the more generous and elastic conditions of the modern state, from a mystical view of the world to a 'realistic one,' is responsible for all the monsters and angels produced by the renaissance. A sphinx, from one point of view, was the result of this release of vitality in all directions. ${ }^{14}$

\footnotetext{
${ }^{11}$ Ibid., 11.

${ }^{12}$ Ibid., 201

${ }^{13}$ Ibid., 84 .

${ }^{14}$ Ibid., 84 .
} 
This sphinx is the renaissance personality who is able to appreciate equally the rarified products of the human intellect and the brutal mechanics of the power-politics of selfinterest. ${ }^{15}$ As an artist situated between two cultural extremes, Shakespeare, Lewis implies, was a "sphinx" of sorts, with a mind expansive enough to encompass fully such extreme cultural contradictions. Unlike the sphinxes that Villari describes (who are capable of great moral and aesthetic sensitivity, but also betrayal, treason and murder), ${ }^{16}$ Shakespeare was interested only in expressing these contradictions in his art. Being a true artist, he was inherently unworldly and opposed to the world of "action." As Lewis states, "This incomparable observer of the life around him 'had his opinions' of what he saw, although he had no gesture of rebellion against individual phases of it, but innumerable gestures against life itself. And, if against life itself, then against action itself." $" 17$ In other words, in order to examine and understand life, he had to remove himself from the world of action; to see life from the outside, and to avoid becoming trapped by its demands for action, he had to become its enemy.

Lewis stresses that although Shakespeare in some ways functioned as a "mirror" in which social conflict was reflected (as is the opinion of those who see Shakespeare as an "impersonal" poet) ${ }^{18}$ he also participated indirectly in this conflict, "had his opinions," and thus offered a comprehensive but also idiosyncratic vision of his time. His non-partisan stance did not preclude, and perhaps even necessitated, the expression of political preferences of a fluctuating and elusive, but no less significant, kind:

\footnotetext{
${ }^{15}$ Ibid., 84-85.

${ }^{16}$ Ibid., 84.

${ }^{17}$ Ibid., 160.

${ }^{18}$ Ibid., 16-20.
} 
The mirror is held up to nature, and there are two fighting forms reflected there-mazdean, moral or not-moral; at all events, a dark and a light, a black and a white....

To be a "mirror" at all, it could be pointed out, is ethically dubious. It could be shown that any mirror that was really a mirror, and which told the truth, would have been smashed long ago. And then it could be suggested that this particular mirror was a very lively one, giving a very purged, not to say peculiar, view of the hegelian "contest" in progress. But in these pages it will be contended that Shakespeare entered furiously into the contest of the two halves of which he was composed. He was alternately as black as night and as white as snow, or both at the same time. The perfection and equilibrium of his mind is the proof of the beautiful matching of the opposing forces. ${ }^{19}$

Thus, the Shakespearean mirror-if it can be called that-sorts out the data it reflects into a dualistic "mazdean" (Zoroastrian) model, although Shakespeare himself possessed characteristics of both the "black" and the "white." He was impersonal in the sense that he was detached from the world of action, but personal in the manner in which he conveyed this world in his plays. Rather than acting as a political partisan, he was able to bring about a "beautiful matching of the opposing forces" due to the "perfection and equilibrium of his mind." To use Schmitt's terminology, Shakespeare divided the characters in his plays into distinct friend/enemy units consisting largely of lions and foxes, and although he sometimes expressed a preference for one over the other, he was

\footnotetext{
${ }^{19}$ Ibid., 23-4.
} 
ultimately incapable of political friendship. Lewis proposes the following answer to the fundamental question raised by Shakespeare's politics:

If the question were put categorically in this form: "On whose side was Shakespeare in the conflict that played such an important part in his work, between the simple man and the Machiavel?" it could not, of course, be answered: or we should have to answer, if at all: "On neither side." For it would not be natural for Shakespeare to intervene in the eternal dispute of good and evil, or in the battles of the animal kingdom, where the foxes and lions perpetually mancvre. It is impossible to make a fox-hunter of him: and he showed no tendency to wish to be a lion. So the answer would have to be complex, as is the phenomenon we are handling. ${ }^{20}$

What enabled Shakespeare to keep his artistic self removed from social and political conflict, Lewis suggests, was his aforementioned estrangement from the world. Lewis goes as far as to identify Shakespeare's underlying attitude as something approaching "nihilism," Schopenhauerian pessimism: a retreat from life, action, and the exercise of the will in favour of a largely aesthetic mode of observation. ${ }^{22}$ Thus, as Lewis sees them, Shakespeare's political "preferences" are not political or moral at root, but rather aesthetic: "As the order of beauty is not an inferior thing to the moral order, so the fact that Shakespeare's goodness is æsthetic virtue, and not the emotion of the moralist, does

${ }^{20}$ Ibid., 178 .

${ }^{21}$ Ibid., 177-180.

${ }^{22}$ See, for example, the aphorisms of Arthur Schopenhauer in "On Aesthetics," from Essays and Aphorisms. 
not make it less pure or valuable. ${ }^{23}$ A moralist must, to some extent, defend an absolute, while the artist-intellectual can conceptualize a conflict of absolutes as an aesthetic whole-a battle of warring abstractions that need not necessarily be resolved into a new synthesis.

The rhetorical gymnastics that Lewis employs in order to make Shakespeare appear simultaneously personal and impersonal reveal not confusion, but the subtlety of Lewis's conception of the role of the artist-intellectual-a conception that evolved throughout his career. The idea of the conflict between the artist-intellectual and the external world is already present in Lewis's 1914 drama Enemy of the Stars, and is developed in the 1925 essay "Physics of the Not-Self," which Lewis refers to as a "metaphysical commentary upon the ideas suggested by the action of Enemy of the Stars" in which the drama is described as representing a conflict between "self" and "not-self."24 The exact meaning of the self/not-self distinction has been the subject of some debate in Lewis criticism, but it may be safely defined as the distinction between the subjective ego and the objective, external world, the latter of which includes the realm of absolute values. $^{25}$

\footnotetext{
${ }^{23}$ Lewis, The Lion and the Fox, 211.

${ }^{24}$ Lewis, "Physics of the Not-Self," 195 . The self/not-self distinction is discussed on pages 196198 of the essay.

${ }^{25}$ Lewis appears to have derived this idea from a variety of sources, including the writings of Johann Gottlieb Fichte, Max Stirner, and F.H. Bradley. Fichte's conception of self and not-self appears in The Lion and the Fox, in what appears to be a quotation from J.J. Bertrand. Lewis, The Lion and the Fox, 216. Stirner's distinction between the unique one and all that is not the unique one seems to prefigure Lewis's conception of the self/not-self distinction. Bradley, who is cited extensively in Time and Western Man, makes frequent use of the self/not-self distinction in Appearance and Reality: A Metaphysical Essay (1893). Bradley, Appearance and Reality, 77-82, et al. Reed Way Dasenbrock, in "The Metaphysics of the Not-Self: Lewis's Explorations in Buddhism," argues that Lewis derived the self/not-self distinction from Buddhist philosophy. James Selby, in "The Physics of the Not-Self: Lewis and the Vedanta," argues that it is derived from Indian Vedanta spiritualism. Most likely, it is a composite drawn from a variety of sources.
} 
In "Physics of the Not-Self," Lewis asserts that all people enter into communion with "truth" or the not-self, "the first stage of which is ingestion," but that few people are able to process and reconstitute the data thus obtained. ${ }^{26}$ These select few are the true artist-intellectuals (of whom, in Lewis's opinion, Shakespeare was surely one) who alienate themselves from society by subjecting the not-self to critical examination. Through this process of critical examination, the not-self becomes internalized and fuses with the intellect, and thus finds a new home within the self of the artist-intellectual. The ordinary person strives to become a part of the not-self, while the artist-intellectual seeks to make the not-self a part of his self; others are incorporated, but he incorporates. In this act of resisting incorporation, however, he becomes viewed by society as a dangerous free radical:

The man who has formed the habit of consulting and adhering to the principle of the not-self participates, it is true, in the life of others outside himself far more than does the contrary type of man, he who refrains from making any use at all of this speculative organ [of the intellect]. But he is not, for that reason, more like other people. He is less like them. For is he not one in a great many thousand? ... [The intellect] is regarded as a breaker-down of walls, a dissolvent of nations, factions, and protective freemasonries, a radio-active something in the midst of more conservative aggregations, as naturally it is. It is an enemy principle. ${ }^{27}$ Within the context of The Lion and the Fox, it may be said that Shakespeare as an artistintellectual is able to ingest and internalize the not-self, and then recreate the not-self in

\footnotetext{
${ }^{26}$ Lewis, "Physics of the Not-Self," 197.

${ }^{27}$ Ibid., 197-98.
} 
his own image, projecting an idiosyncratically distorted replica of objectivity. That this process is different from the simple "reporting" of events is a crucial distinction to make; as I have already noted, Shakespeare was not, according to Lewis, just a "mirror." The act of mental ingestion is an act of understanding that assimilates and transforms data received from the external world; the self acts as a filter, and the indexical imprint of the self that emerges in a work of art reflects the artist's unique way of seeing the world.

Paul Edwards sees a contradiction in Lewis's argument regarding Shakespeare's authorial stance, in that although Lewis portrays Shakespeare as possessing a clearly defined artistic personality removed from its time-period, he also suggests that this personality is determined by a specific historical context:

the 'personality' in [Lewis's] argument can only be a transcendent noumenon expressing characteristics that must be described through their non-personal (primarily, in The Lion and the Fox, historical) origins. Shakespeare's 'personality' becomes a site where certain historical and cultural forces meet and wage their battle. However much Lewis wishes to insist on a prior 'personality,' his analysis effectively deconstructs it and converts it, as neatly as any postMarxist critic could desire, into historical process. ${ }^{28}$

This is an important observation, but there is a twist in Lewis's argument that Edwards overlooks. The Lewisian clerc (in this case, Shakespeare) is shaped by his historical context in the same way that the self is shaped by its relation to the not-self. The self is revealed through the manner in which it processes and reconstructs the data it receives

\footnotetext{
${ }^{28}$ Edwards, Wyndham Lewis: Painter and Writer, 296.
} 
from the not-self. It is tangible only to the extent that it engages with the not-self, but it does not originate in the not-self. The self wrestles with that which tries to determine it (the not-self), just as Arghol wrestles with Hanp in Enemy of the Stars, and must remain in this state of conflict and contradiction in order to exist. Shakespeare absorbed as much of the not-self as his unusually vast self would allow, but, in creating his tragedies, he performed the equally herculean task of impressing his personality upon the data thus received. His attention to the "historical and cultural forces" of his time and his internalization of them made him more of a "personality" than he would have been otherwise, for as Lewis makes clear in "Physics of the Not-Self," the more one absorbs and incorporates the data received from the not-self, the more one must resist being incorporated. The unincorporated but culturally aware artist-intellectual thus becomes increasingly a unique individual, a "personality," and ultimately an enemy.

Lewis's unusual model of Shakespeare's creative dynamic is what makes The Lion and the Fox important in Shakespearean criticism as a whole, as Edwards acknowledges. ${ }^{29}$ Lewis sees Shakespeare's 'impersonalism' as a mask and does not claim, as some Shakespeare critics have, that he was only a mirror, or that he was an artistic force of nature:

There are only different ways of being personal; and one of them is that admired method of insinuation whereby a particularly compendious pretended reality enables its creator to express himself as though he were nature, or a god. But it is

$$
{ }^{29} \text { Ibid., } 297 .
$$


never as nature, or as the god responsible for this world, that a great creative artist speaks; nor does he ever identify himself with this other actuality. ${ }^{30}$

This statement is awkwardly worded; what Lewis says is that although the great artist does not attempt to convince himself that he is speaking as nature, he may allow his audience to be fooled by his veneer of impersonality. Lewis continues, noting that "The 'impersonal' fallacy appears in the light of a genial bluff; it is a similar device to that whereby a man hunting a seal will cover himself with the skin of a dead seal, and, disguised in that way, stalk his prey." ${ }^{\text {"31 }}$ Such feigned impersonality, Lewis suggests, was used by Shakespeare out of necessity, given that his art was a criticism of the world of action. As Lewis explains, "it is impossible to be both a poet and a man of action, to be Homer and Hector, or Shakespeare and Cæsar; . . . it is natural, we should also say, or even necessary, that the poet should be 'impersonal.' For he has to fit into the lives of his subjects and not they into his." 32 The true Shakespeare, Lewis claims, can only be found by looking underneath the mask of impersonalism, for "In spite of the placid and 'gentle' surface of this mirror of a man, we know the storms that raged beneath it; and we know that he must, personally, have suffered as much from the world around him as any of his heroes." ${ }^{\text {33 }}$ Shakespeare seems to be impersonal, yet his opinions regarding the actions of his characters can be deciphered (which Lewis attempts to do at points), thus revealing his personality, or at least the personality of the implied author of his works. ${ }^{34}$

\footnotetext{
${ }^{30}$ Lewis, The Lion and the Fox, 286.

${ }^{31}$ Ibid., 286.

${ }^{32}$ Ibid., 288.

${ }^{33}$ lbid., 289.

${ }^{34}$ See, for example, pages $238-39$, in which Lewis detects an anti-aristocratic (and proto-antiNietzschean) bias in Shakespeare, based on a seemingly offhand comment made by Valeria in regards to Coriolanus in Coriolanus.
} 
Whether Lewis's interpretation of Shakespeare's impersonalism is truly a novel observation within the context of Shakespearean criticism is debatable, but its implications within the context of Lewis's work are far-reaching. In many of Lewis's works, his authorial stance involves a contradiction: he appears to maintain an attitude of cold indifference towards his subject matter, and to position himself outside the world of action, while at the same time engaging in polemical discourse that displays a raw, almost visceral energy. This contradiction is resolved, however, when one considers Lewis's self/not-self model in relation to his analysis of Shakespeare. Lewis does not simply stand outside the kulturkampf; he ingests it in its totality. Only after such ingestion is completed can he fully engage with the kulturkampf-tear it apart or dirempt it-without losing his outsider status. His initial act of sorting cultural conflict into a great dichotomy is his means of making it tangible as a whole, so that it can be fully ingested.

It is likely that Lewis's conception of Shakespeare's (and his own) creative process was derived in part from one of Lewis's early philosophical influences: Max Stirner. ${ }^{35}$ Stirner was a student, and opponent, of Hegelian thought who offered a philosophical justification for radical egoism in his only major work, The Ego and its Own (1844). He proposed that the dawning phase in the development of human consciousness-the era of the egoist-demands that the ego free itself from all constraining value-structures, and particularly those of Christianity and humanism. In Stirner's opinion, the individual ego-not merely "an ego along with other egos, but the sole ego"

\footnotetext{
${ }^{35}$ The Ego and its Own (along with an apparition of Stirner himself) appears in Lewis's Enemy of the Stars (1914). The appearance of Stirner in the play has been addressed, to a limited extent, in Lewis criticism. See, for example, Foshay, Wyndham Lewis and the Avant-Garde, 31-32, and Edwards, Wyndham Lewis: Painter and Writer, 157-159.
} 
or "the unique one," 36 as Stirner puts it-debases itself and loses its uniqueness when it submits to any sort of " "fixed idea'."37 It should rather consider all that it finds in the outside world as its potential property, or the property of "the unique one," to be used and disposed of at its will. Stirner, speaking from the perspective of the egoist, proclaims, "Where the world comes in my way-and it comes in my way everywhere-I consume it to quiet the hunger of my egoism. For me you are nothing but-my food, even as I too am fed upon and turned to use by you." 38 The other is something to be eaten, incorporated, and used by the ego, for its own special purposes. Hegel, in his conceptualization of the distinction between self and other, turns the self into an abstract, universal idea, but Stirner speaks only for one self: his own. Criticizing the Hegelian view of the mind, Stirner remarks, "Absolute thinking' is that which forgets that it is $m y$ thinking, that $I$ think, and that it exists only through me. But I, as I, swallow up again what is mine, am its master; it is only my opinion, which I can at any moment change, annihilate, take back into myself, and consume." 39 Again, Stirner uses a food metaphor to describe the consumption and incorporation of the world (or in Lewis's terms, the not-self) by the unique ego.

For Lewis, as his study of Shakespeare shows, the ego of the artist-intellectual functions in the same way. It is not a slave to the absolutist moral stances of the kulturkampf, but rather envelops and consumes these orthodoxies-making them its own-and twists and rearranges them in order to create a new, provisional politics that

\footnotetext{
${ }^{36}$ Stirner, The Ego and its Own, 319.

${ }^{37}$ Ibid., 43.

${ }^{38}$ Ibid., 263.

${ }^{39}$ Ibid., 300.
} 
reflects its own uniqueness and independence. Shakespeare, it is implied, was aware of the uniqueness of his own ego, and of the dangers posed to it by the outside world.

Stirner's egoism, despite its focus on the self, has political implications which are relevant to both The Lion and the Fox and to Lewis's later work. In a particularly pertinent remark in The Ego and its Own, Stirner describes a politics of the egoists (or "the own") that might have influenced Lewis's view of Shakespeare's "opinions" regarding the world of action, as well as the development of Lewis's own political strategies:

Are the own or unique perchance a party? How could they be own if they were such as belonged to a party?

Or is one to hold with no party? In the very act of joining them and entering their circle one forms a union with them that lasts as long as party and I pursue one and the same goal. But today I still share the party's tendency, as by tomorrow I can do so no longer and I become 'untrue' to it. The party has nothing binding (obligatory) for me, and I do not have respect for it; if it no longer pleases me, I become its foe. ${ }^{40}$

Stirner here expresses both an unwillingness to form a lasting union with any kind of party, and a willingness to use parties to his own advantage. Because he is the sovereign "unique one," he is free to abandon his political commitments as soon as they threaten his uniqueness. Lewis does not portray Shakespeare as a pure Stirnerean egoist, although his description of Shakespeare's "nihilism" and his fluctuations between involvement

\footnotetext{
${ }^{40}$ Ibid., 211.
} 
with and detachment from life point in that direction. Lewis himself, however, especially in his later Enemy phase, displays elements of a Stirnerean ethic in his approach to politics-an ethic which is in its gestational phase in The Lion and the Fox.

Lewis's argument in The Lion and the Fox may be summarized as follows. In his tragedies, Shakespeare addresses the cultural contradictions of his time by donning a mask of impersonality and functioning as a "mirror"; he is then able to tilt or distort the mirror in ways that convey a picture of the cultural totality as filtered through his unique personality. This way, he is able to express his personal political opinions without allowing himself to be categorized according to the friend/enemy divisions recognizable to the culturo-political partisans of the Renaissance (the lions and the foxes). Thus, through the mental ingestion of the not-self, the artist-intellectual is able to engage with life without being drawn into partisan action. Attentive readers will be able to discern, in the artist-intellectual's reflection or re-creation of the external world, the imprint of a unique self.

The creative process that Lewis identifies in Shakespeare also functions as the basis of Lewis's method of creation. In all his work, he separates self and not-self by positioning himself as a non-partisan artist-intellectual observing the political from the privileged perspective of the outsider. He sorts the data he receives from the not-self into a dualistic framework, separating "black" from "white"; after this act of mental ingestion he performs an act of mental digestion as he imposes his unique self (and all his personal biases) upon the political landscape he has delineated, "blessing" what is useful and 
"blasting" what is harmful, carving out a niche for himself (and those like him). ${ }^{41}$ The resulting artistic or intellectual product, whether a tract, novel, or painting, represents the reconstituted not-self. Fragments of what were previously monolithic entities are forged into new patterns and harmonies, and point to new possibilities for art and the intellect.

The method outlined above forms the analytical basis of The Art of Being Ruled, in which Lewis wrestles with the twentieth-century kulturkampf. This work of cultural criticism is one of Lewis's most complex creations; its sprawling analysis of a diverse range of political phenomena seems designed (in classic modernist manner) to repel the casual reader. Even among Lewis critics it remains a problematic text, and there is still debate over what exactly Lewis was trying to say in the book. The "shifting, mobile perspective" that Dasenbrock identifies has been the cause of a variety of misunderstandings regarding Lewis and especially his opinions on fascism; ${ }^{42}$ nevertheless, it is one of the book's most significant aspects. The ideological ambiguity implied in Lewis's analysis is not a compositional shortcoming, but rather a conscious strategy that Lewis uses to engage with the kulturkampf, and a manifestation of the strategies that he admired in Shakespeare's work. His goal is to bring about a balance of

\footnotetext{
${ }^{41}$ I am alluding here to Lewis's famous "Bless" and "Blast" list from "Great Preliminary Vortex-Manifesto-I," in BLAST 1 (1914).

${ }^{42}$ See, for example, John R. Harrison's The Reactionaries (1966). Harrison quotes Lewis's remarks on page 364 of The Art of Being Ruled regarding the possibility of a separation of artistintellectuals and ordinary people, and its potential biological consequences. Because he fails to see that Lewis is merely speculating in a half-ironic manner, he is able to leap to the conclusion that "This idea is very much like Nietzsche's doctrine of the superman, and the Nazi doctrine of the master race. Lewis wants to breed a superior race which could organize society into a sensible pattern, while taking an interest in higher forms of life." Harrison, The Reactionaries, 101. Lewis's irony aside, there is a difference between a biologically-reinforced separation of people, which Lewis considers, and a biologically-reinforced hierarchy of power, which the Nazis advocated.
} 
ideas, or what he identifies in Shakespeare as the "beautiful matching of the opposing forces."

Generally speaking, The Art of Being Ruled is comprised of an analysis of the social and political phenomena produced during the period of transition between the old nineteenth-century world of liberal democracy and a coming socialist world-order. The conceptual framework of The Lion and the Fox is transferred into the modern age, with Lewis taking the place of Shakespeare, and Georges Sorel assuming the role of Machiavelli; rather than focusing on the "realism" of the early moderns, Lewis focuses on the new science of socialism.

Already in The Lion and the Fox, there is evidence that Lewis saw himself as living in a "period of transition" as significant as that of the Renaissance. Lewis finds a point of comparison in Villari's analysis of the sphinx-like Renaissance personality and the cultural contradictions it represented:

When Villari wrote, in the middle of the nineteenth century, those contradictions would be more difficult to reconcile than they are to-day, in the first place. For today we are in the midst of a 'transitional' period, on a vast scale, and which provides us (although heavily disguised in patriotic formulæ or in revolutionary altruism, and therefore more complex and baffling) with contradictions just as notable. $^{43}$

In the modern world, Lewis suggests, such sphinx-like figures are just as prevalent and even more problematic. In The Art of Being Ruled, the major intellectual figures on

\footnotetext{
${ }^{43}$ Lewis, The Lion and the Fox, 85.
} 
whom Lewis focuses, namely Rousseau, Proudhon, Nietzsche, and Sorel, are all modern intellectual sphinxes-or those who revel in extreme cultural contradictions. For Lewis, Sorel, in particular, emerges as the most representative political philosopher of the transition: "intellectually [Sorel] is a sensitive plate for the confused ideology of his time. He is a semitaur who sees red both ways, the bull-nature injects the human eyes with blood. He is, in brief, a symptomatic figure that it would be difficult to match., ${ }^{\prime 4}$ Hence, as such, "George Sorel is the key to all contemporary political thought." ${ }^{\prime 45}$ This emphasis on the importance of Sorel is, as I have already mentioned, the aspect of The Art of Being Ruled that Carl Schmitt found most worthy of praise, perhaps because Sorel's insistence on the importance of the idea of the enemy (real or imagined) in revolutionary ideology corresponded with what might have been Schmitt's developing idea of the friend/enemy distinction as the essence of the political.

It is Sorel's philosophy of violence-his idea that it is only through the myth of an impending apocalyptic battle that a social group can develop cohesion, discipline, and the will to revolt-that Lewis sees permeating Western politics and informing the structure of an increasing number of cultural conflicts and crusades. ${ }^{46}$ This focus on conflict and confrontation is, as Dasenbrock's analysis of the book suggests, crucial to understanding The Art of Being Ruled: "Modern society is increasingly defined, according to Lewis, by

\footnotetext{
${ }^{44}$ Lewis, The Art of Being Ruled, 119.

${ }^{45}$ Ibid., 119.

${ }^{46}$ Sorel outlines his philosophy of violence and class warfare in Reflections on Violence (1908). Leszek Kolakowski captures Sorel's uniqueness in relation to mainstream reformist Marxism in the following passage from Main Currents of Marxism 2 (1978): "Marxism, to Sorel, was above all the poetry of the Great Apocalypse which he identified with social revolution. He combated reformism not because it was ineffectual-on the contrary, he knew it to be effective-but because it was prosaic and unheroic." Kolakowski, Main Currents of Marxism 2, 170.
} 
a series of 'wars.' ... And the bulk of The Art of Being Ruled is devoted to a critical examination of the ideologies behind these various wars: socialism, feminism, and the 'cults' of the child and of homosexuality." ${ }^{, 47}$ Lewis specifically describes these conflicts as wars of "one half against the other," "48 borrowing the words of a character in Ernest Renan's Caliban (1878) who remarks, "As a rule, all heroism is due to a lack of reflection, and thus it is necessary to maintain a mass of imbeciles. If they once understand themselves the ruling men will be lost. A man rules by employing one half of these animals to conquer the other half. In the same way the art of politics lies in dividing the people and controlling each section by means of the other." ${ }^{\prime 49}$ Each of these wars, Lewis suggests, is artificially manufactured by a revolutionary "intelligence" that is "a religious rather than a political intelligence" or "an unspoilt and primitive source whose will is so great that it clothes itself naturally in the form of a god." ${ }^{90}$ Foreshadowing latetwentieth century frustration with "political correctness," Lewis describes these wars as producing hostile political factions ready to pounce upon anyone who dares to speak freely: "We live beset with civil wars, in the envenomed and bitterly organized world. Almost any generalization must range against you the legions of this or that zealous social host, daily subjected to press discipline, breathing defiance, whether really affected by your statement or not." 51

Lewis ranks these kulturkampfen in terms of importance and identifies a number of larger dichotomies in the world of modern ideas under which these socio-political

\footnotetext{
${ }^{47}$ Dasenbrock, Afterword to The Art of Being Ruled, 439.

${ }^{48}$ Lewis, The Art of Being Ruled, 184.

${ }^{49}$ Qtd. in Lewis, The Art of Being Ruled, 184.

${ }^{50}$ lbid., 76.

${ }^{51}$ Ibid., 185.
} 
phenomena may be categorized. Thus, the idea of "revolution" is the central political phenomenon analyzed in The Art of Being Ruled, with "reaction" or tradition being the submerged second term in the implied antinomy. Lewis's idea of what constitutes reaction, however, is qualified by his statement at the beginning of the first chapter, that "Every one today, in everything, is committed to revolution." ${ }^{.52}$ In other words, while flourishing reactionary movements may exist, they are continuously undermined by an all-pervasive historical tendency towards revolution. Within the realm of revolution proper, Lewis distinguishes between "creative" and "destructive" revolution, ${ }^{53}$ thus delineating a smaller kulturkampf within a larger one. Again, Lewis chooses to focus on only one term in this antimony, and much of The Art of Being Ruled reads like a catalogue of what Lewis sees as the various types of destructive revolution, including feminism, shamanism (homosexuality), the vulgarization of philosophy, artistic amateurism and dilettantism, and, especially, hatred of the intellect. In the last section of the book, entitled "Beyond Action and Reaction," Lewis addresses the kulturkampf in the broadest terms possible, outlines the ideas behind his "politics of the intellect," and suggests the possibility of an attempt to transcend the action/reaction (or revolution/reaction) dichotomy. ${ }^{54}$

Lewis's ultimate goal in The Art of Being Ruled is twofold: he wishes to promote creative revolution among artist-intellectuals while warning them of the danger and seductiveness of destructive revolution. If there is a utopian vision that can be assembled

\footnotetext{
${ }^{52}$ Ibid., 17.

${ }^{53}$ Ibid., 25.

${ }^{54}$ Ibid., 373-75.
} 
from the scattered fragments of positive doctrine in The Art of Being Ruled, it is one of a world-government in which the masses (or "puppets") would be pacified through the direct but transparent control of a small group of anti-democratic leaders; for their part, the artist-intellectuals (or "natures") would be allowed to function in isolation, without the need for political power, as a sort of liberally-organized syndic or corporation. ${ }^{55}$ This utopia is purely theoretical, however, and Lewis does not propose a plan of action through which it might be brought about. What he does do, on a more pragmatic level, is seek to make artist-intellectuals like himself aware of the danger of the political, a message that is encapsulated in a quotation from a fragment by Parmenides that closes the work: "I wish to communicate this view of the world to you exactly as it manifests itself: and so no human opinion will ever be able to get the better of you." Being Ruled may thus be viewed as something similar to a military reconnaissance report describing the hostile territories through which all artist-intellectuals (or those inhabiting a realm above that of merely "human opinion") must necessarily tread.

In his introduction, Lewis displays doubt as to whether the book can perform its intended function, given that his intended audience might not exist: "[This book] must of necessity make its own audience; for it aims at no audience already there with which I am acquainted. I do not invent ... a class of esprits libres, or 'good Europeans,' as Nietzsche did. I know none." ${ }^{57}$ In other words, his prospective audience must be shaken

\footnotetext{
55،"Natures' and 'Puppets"' is the title of Part V of The Art of Being Ruled. The terms are taken from Goethe. Lewis, The Art of Being Ruled, 124-5. Many of the passages describing Lewis's fragmentary utopian vision appear in Part XIII, entitled "Beyond Action and Reaction." See especially pages $357-58,364,367-68,374-75$.

${ }_{56}$ Parmenides. Fragment VIII. 60-61. Qtd. In Lewis, The Art of Being Ruled, 375.

${ }^{57}$ Lewis, The Art of Being Ruled, 13.
} 
into awareness of the kulturkampf and its threat to the intellect. Lewis recognizes that such a manoeuver is risky, in that it may entail his ideas being subjected to the very vulgarization of thought that he repeatedly denounces. Referring to Nietzsche, whom Lewis sees as a vulgarizer of the aristocratic ideal, Lewis writes, "To address passionately and sometimes with very great wisdom people who do not exist has this disadvantage ... that there will always be a group of people who, seeing a man shouting apparently at somebody or other, and seeing nobody else in sight, will think that it is they who are being addressed." ${ }^{, 8}$ Even at this stage in the development of his political thought, Lewis realized that the writings and ideas of a political free radical may be harnessed by those with different, and likely politically partisan, interests. Given Lewis's skepticism regarding the abilities of the masses and even of the majority of intellectuals, The Art of Being Ruled is more a survival-guide for an imaginary elite than a call for social change.

The process of analysis by which Lewis exposes cultural contradictions and attempts to balance them is essentially the same as that he ascribes to Shakespeare, as his ideal artist-intellectual. As a first step in his analysis, he identifies the content of the particular kulturkampf he is describing by revealing and clarifying its dualistic nature. In his discussion of the difference between creative and destructive revolution, for example, Lewis invokes the "ancient and valuable iranian principle of duality" in order to differentiate between the "fighter and killer," on one hand, and the "civilizer and maker," on the other. ${ }^{59}$ Referring to the two Zoroastrian deities representing darkness (or evil) and light (or good), he comments, "It is hoped that certain things that have flown a grey and

\footnotetext{
${ }^{58}$ Ibid., 116.

${ }^{59}$ Ibid., 25.
} 
neutral flag will be forced to declare themselves as Ozman or Ahriman, the dark or the light." ${ }^{60}$ Lewis uses the same method to create literary portraits of a host of cultural contradictions, many of which he names in the table of contents, such as "agricultural thought and industrial thought," "liberalist democracy and authority," "the ruler and the ruled," "natures' and 'puppets"," "the family and feminism," "man and shaman," and "democratic freedom and the caste community."

The next step in Lewis's method, in which he examines each of the monolithic ideological entities that constitute these dichotomies, is what may be described as a process of "diremption," to adopt a term used by Sorel (and which has appeared in Lewis criticism before) in "Unity and Multiplicity," an appendix to the second edition of Reflections on Violence. ${ }^{62}$ Sorel offers an explanation of his concept of diremption:

Social philosophy is obliged, in order to study the most significant phenomena of history, to proceed to a diremption, to examine certain parts without taking into account all of the ties which connect them to the whole, to determine in some manner the character of their activity by isolating them. When it has thus arrived at the most perfect understanding, it can no longer attempt to reconstitute the broken unity. ${ }^{63}$

The diremptive method allows Lewis to "bless" and "blast" at will, praising certain aspects of a particular ideology while condemning others. As a result, he is able to

\footnotetext{
${ }^{60}$ Ibid., 25-6.

${ }^{61}$ Ibid., 7-10.

${ }^{62}$ Philip Head examines the influence of Sorel's diremptive method on Lewis, albeit briefly, in "From Diremption to Deconstruction" in Some Enemy Fight-Talk: Aspects of Wyndham Lewis on Art and Society, 153-158.

${ }^{63}$ Sorel, "Unity and Multiplicity," 259.
} 
display his personal "preferences" without being forced to make a declaration of ideological allegiance. As Lewis's process of diremption proceeds, and the ideological structures that constitute the orthodox Old and New are dismantled, the initially dualistic representation of the kulturkampf disintegrates, and in Sorelian fashion, Lewis makes no "attempt to reconstitute the broken unity." The reader is left in a shattered ideological landscape-one that is nevertheless pregnant with the possibility of new and more complex ideological constructions. Thus, although Sorel used the diremptive method to create ideological divisions within existing orthodoxies, ${ }^{64}$ Lewis uses the diremptive method to dismantle the rigid ideological conflicts that Sorel himself helped create.

It must be stressed that Lewis's technique is not merely destructive. Lewis attacks the battling forces of ideological orthodoxy in The Art of Being Ruled as a means of advocating a type of ideological pluralism that would incorporate the best elements from the history of human thought. He goes as far as to suggest that the cultural developments of the twentieth century have created an unprecedented opportunity for those willing to step outside of the flow of history and survey the panorama of the past: "We have ... to some extent reached a point at which we can see all the possibilities of human life, so far as it is to be physically constant and intellectually constant.... Out of the integral impression [of the possibilities of human life] we should construct our new political equilibrium." ${ }^{\prime 65}$ Lewis's goal is to subject the kulturkampf to a process of diremption, to

\footnotetext{
${ }^{64} \mathrm{See}$, for example, Sorel's treatment of Marxist theory in "The Decomposition of Marxism" (1908).

${ }^{65}$ Lewis, The Art of Being Ruled, 325.
} 
isolate and study the cultural and political contradictions of the twentieth century, and aid in bringing about a "new political equilibrium."

This idea of "political equilibrium" is a vague but crucial element of Lewis's thought. In his second autobiography, Rude Assignment (1950), Lewis explains the argumentative structure of The Art of Being Ruled, remarking that "It was my idea at the outset-inspired by the Hegelian dialectic, with its thesis and antithesis-to state, here and there, both sides of the question to be debated, and allow these opposites to struggle in the reader's mind for the ascendancy and there to find their synthesis. I did not take this very far; vestiges of it nevertheless exist, a source of occasional embarrassment." ${ }^{" 66}$ Here, Lewis appears to dismiss as a casual experiment what is essentially the structuring principle of The Art of Being Ruled. Also, despite Lewis's retrospective claim, the Hegelianism in The Art of Being Ruled has little to do with a strict interpretation of Hegelian dialectics. Lewis's aforementioned ideal of "political equilibrium" is, rather, strongly reminiscent of Proudhon, who is discussed extensively in the book.

Proudhon, with his focus on social and economic contradictions, adopted Hegel's idea of dialectic in his earlier work but came to modify it significantly. In Theory of Property (1863-64) he describes how his ideas regarding property changed by the time he wrote the third section of Justice in the Revolution and the Church (1858):

I . . . substituted the principle of balance for that of synthesis. Until then I had shared Hegel's belief that the two terms of the antinomy, thesis and antithesis, were to become resolved in a superior term, synthesis. But I have since come to

\footnotetext{
${ }^{66}$ Lewis, Rude Assignment, 183.
} 
realize that just as the two poles of an electric cell do not destroy each other, so the two terms of the antinomy do not become resolved. Not only are they indestructible, but they are the very motive force of all action, life and progress. The problem is not to bring about their fusion, for this would be death, but to establish an equilibrium between them-an unstable equilibrium, that changes as society develops. ${ }^{67}$

Given Lewis's refusal to attempt to create a new synthesis out of the cultural and political contradictions that he isolates, it would seem that Proudhon, rather than Hegel, provided Lewis with his dialectical model for The Art of Being Ruled. Lewis does mention the idea of synthesis in the above passage from Rude Assignment, but suggests that his goal was to "allow these opposites to struggle in the reader's mind for the ascendency and there to find their synthesis." Hegel's system is founded upon a universal logic, while Lewis's method allows for individualistic interpretation of dialectical processes; thus Lewis's dialectical method is essentially playful and experimental rather than pedantic. If the Hegelian view of history ultimately leads towards what Alexandre Kojève famously referred to as the "universal and homogenous state," leads towards a potentially universal but heterogeneous state, in which change, growth, and creativity are still possible.

\footnotetext{
${ }^{67}$ Qtd. in Proudhon, Selected Writings, 229.

${ }^{68}$ Kojève sees Hegelian thought as moving towards a prospective "end of History" and the formation of a world-state based on the "absolute Knowledge of the Wise Man": "It was always known that for Hegel, not only does the coming of Wisdom complete History, but also that this coming is possible only at the end of History. This is known, but why this is true is not always very well understood. And one cannot understand this as long as one does not know that the Wise Man must necessarily be Citizen of the universal (i.e., nonexpandible) and homogenous (i.e., nontransformable) State." Kojève, Introduction to the Reading of Hegel, 95.
} 
In any case, what emerges in The Art of Being Ruled is a distinction between the existing kulturkampf that has become endemic and a potential state of political equilibrium in which opposing political forces may be released from their ideological chains and brought into something approaching harmony. One way of creating political equilibrium, Lewis suggests, is for the burgeoning world state to adopt a mixed system of government in which the "natures" (or the minority of people who have the capacity for independent thought) are separated from the "puppets" (or those who can only find happiness in being controlled and constantly stimulated). The natures would acquire intellectual freedom at the price of exile from the world of power and action, while the puppets would exchange their intellectual freedom for a life without true intellectual labour or personal responsibility. The political contradiction between anarchism (for the natures) and fascism (for the puppets) forms the basis of the political system that Lewis proposes; his notorious consideration of "fascism as an alternative" to liberal democracy for the organization of society at large must be seen in light of his simultaneous call for an anarcho-syndicalist union of artist-intellectuals, or those who exist outside of society. ${ }^{69}$ Thus, Lewis's praise for authoritarianism in The Art of Being Ruled is counterbalanced by his equally vociferous championing of personal freedom (for those who, according to Lewis, actually desire it and would benefit from it).

It would thus be misleading to describe Lewis's view of the role of the artistintellectual as being strictly authoritarian in nature, or in other words, that Lewis believed that artists should directly influence society through anti-democratic means. Indeed,

\footnotetext{
"69"Fascism as an Alternative" is the title of a short chapter in The Art of Being Ruled. Lewis, The Art of Being Ruled, 319-322.
} 
Lewis's outsider criticism, which is geared towards political non-intervention, has an unlikely philosophical pedigree in Chinese Tâoism. The Art of Being Ruled includes no less than seven epigraphs quoting the ancient Tâoist philosopher Chuang-Tzŭ (referred to as Kwang-tze by Lewis), which display an affinity for Tâoism that contradicts Lewis's alleged support of fascism. The first epigraph is as follows:

That view involves both a right and a wrong . . are there indeed, or are there not, the two views, that and this? They have not found their point of correspondency which is called the pivot of the Tâo. As soon as one finds this pivot, he stands in the centre of the ring (of thought) where he can respond without end to those affirming, and without end to those denying. ${ }^{70}$

The section of Chuang-Tzŭ's writings from which Lewis is quoting is entitled "Khî Wû Lun," or, as it is translated in the James Legge translation that Lewis used, "The Adjustment of Controversies'." The Tâo is, according to Chuang-Tzŭ, the great organizing force of the universe, and existed (if it may be said to exist at all) prior to all human notions of right and wrong. "Khî Wû Lun" deals specifically with the problem of disputation in human thought and speech, and poses the question, "how can the Tâo be so obscured that there should be 'a True' and 'a False' in it? How can speech be so obscured that there should be 'the Right' and 'the Wrong' about them?"71 One of the examples of disputation provided in the text is the philosophical argument between the "Literati" (the Confucians) and the Mohists (or followers of the philosopher Mozi)-two religiophilosophic groups with radically opposing views, "the one side affirming what the other

\footnotetext{
${ }^{70}$ Qtd. in Lewis, The Art of Being Ruled, 16.

${ }^{71}$ Chuang-Tzŭ, "Khî Wû Lun," 181.
} 
denies, and vice versa." ${ }^{, 72}$ The advice given on how to deal with such disputes or controversies in a sagely manner is to view them according to "the (proper) light (of the mind), "73 or, in other words, from the perspective of the Tâo. From this perspective, seemingly insoluble controversies may be viewed as component parts of a greater unity. Later in "Khî Wû Lun," in a passage that Lewis does not quote in The Art of Being Ruled but that he likely read, the proper role of the sage is expanded upon, with reference to an early Chinese historical work (the "Khun Khî̂" or the "Spring and Autumn" Annals of Lû):

Outside the limits of the world of men, the sage occupies his thoughts, but does not discuss about anything; inside those limits he occupies his thoughts, but does not pass any judgments. In the Khun Khiû, which embraces the history of the former kings, the sage indicates his judgments, but does not argue (in vindication of them). Thus it is that he separates his characters from one another without appearing to do so, and argues without the form of argument. How does he do so? The sage cherishes his views in his own breast, while men generally state theirs argumentatively, to show them to others. Hence we have the saying, 'Disputation is a proof of not seeing clearly. ${ }^{, 74}$

Lewis seems to follow this advice, as he displays a marked reluctance in The Art of Being Ruled to pass judgment on the phenomena he is observing. Judgments are implied, of course, in the degree to which each of the ideologies he analyzes is subjected to satirical

\footnotetext{
${ }^{72}$ Ibid., 182.

${ }^{73}$ Ibid., 182.

${ }^{74}$ Ibid., 188-189.
} 
scrutiny, but Lewis consistently refrains from backing up these judgements with the kind of argumentation traditionally expected of the polemicist, such as appeals to unchanging moral standards. It has been said that Lewis's works may be placed within the tradition of the "Victorian sage,"75 but this classification does not take into account Lewis's aversion to political or moral engagement. If Lewis is attempting to emulate the sage, it is the Taoist rather than the Victorian sage that he is using as his model. In the same way that he strives to find the centre of the vortex in his visual art, in his criticism he attempts to find "the pivot of the Tâo." If Ezra Pound emulated Confucius in his cultural criticism (which is often dogmatic and prescriptive), then Lewis looked instead to Chuang-Tzŭ and even Lao-tzŭ, the foundational Tâoist philosopher whom he quotes in an epigraph within a later work, "The Diabolical Principle.""76

Lewis's purpose in both The Lion and the Fox and The Art of Being Ruled is to determine how the artist-intellectual might be able to carve a niche for himself outside of the political structures that infest human life-and especially the forms they assume in the kulturkampfen of periods of transition. Thus, contrary to what a casual reader of The Art of Being Ruled might assume, Lewis's vision of a future society is not one in which intellectuals will be placed in positions of political power. Lewis, in fact, espouses the opposite, saying "Their [the intellectuals'] great political services should be evident to

\footnotetext{
${ }^{75}$ This connection between Lewis and the Victorian sage is made in Walter Allen's 1963 essay on Lewis, "Lonely Old Volcano," although the idea of the Victorian sage itself is taken from John Holloway's The Victorian Sage: Studies in Argument (1953), as Allen acknowledges. Allen writes, "When one views his work as a whole, Lewis, it seems to me is extremely close to the kind of writer John Holloway calls the Victorian Sage in his book of that name. Holloway's examples are Carlyle, Disraeli, George Eliot, Newman, Arnold and Hardy." Allen, "Lonely Old Volcano," 64. ${ }^{76}$ Lewis, "The Diabolical Principle," 1.
} 
anybody. But if pure science and the free speculative mind are to survive, they must evidently at this point divorce themselves from politics. It is in order to escape from politics that it is necessary to analyse this situation so radically." ${ }^{.77}$ Both The Lion and the Fox and The Art of Being Ruled explain why this "escape from politics" is advisable, and how it might be accomplished.

Lewis sees the kulturkampf as a phenomenon with the power to crush the intellect, and recommends a policy of political restraint on the part of the intellectuals, rather than political commitment. The Lion and the Fox offers Shakespeare as the model of the ideal artist-intellectual, who is able to internalize and re-conceptualize the kulturkampf and resist becoming a partisan pawn. The Art of Being Ruled represents Lewis's attempt to play this Shakespearean role in his cultural criticism and to wrestle with the kulturkampf by revealing and then dismantling the antinomies that constitute its framework.

${ }^{77}$ Lewis, The Art of Being Ruled, 335. 


\section{Chapter Two}

A White Man in a Dark Shirt: The Enemy and the Kulturkampf Shortly after the publication of The Art of Being Ruled and The Lion and the Fox, Lewis entered what may be roughly described as his "Enemy" phase, founding in 1927 his journal The Enemy, in which the essays that were later published in book form in Time and Western Man (1927), Paleface (1929), and The Diabolical Principle and the Dithyrambic Spectator (1931) first appeared. As the Enemy, Lewis became something of a professional controversialist, attacking and ridiculing many of the prominent trends in modern culture. Although Lewis claimed to be politically non-partisan, his relentless attacks on all that was "modern" left him open to the accusation that he had become, despite his avant-garde credentials, a reactionary. One such accusation arrived in the form of a 1927 article entitled "First Aid to the Enemy," by the editors of transition magazine (Eugene Jolas, Elliot Paul, and Robert Sage); in the article, they ridicule Lewis's claims to avant-garde status, accusing him of being "A good old Tory at heart." This accusation is in many ways unfair, but I nevertheless propose that it be taken seriously, for it reveals a crucial site of ambiguity and tension in Lewis's thought. Most Lewis critics would agree that Lewis was not a "good old Tory," as the transition editors allege, but there is some evidence that in the late 1920s and 30s, Lewis was attempting, in his highly individualistic manner, to contribute to what his contemporary, Henri Massis, referred to as the "défense de l'occident" or the "defence of the west." Father Martin D'Arcy, in The Nature of Belief (1931), even classifies Lewis as one of the

\footnotetext{
'Jolas, Paul, Sage, "First Aid to the Enemy," 165.

${ }^{2}$ Défense de l'Occident is the title of a 1927 book by Massis.
} 
"contemporary witnesses of the Crisis in the West," along with such reactionary

luminaries as Léon Bloy, Julien Benda, Jacques Maritain, Nicolas Berdiaeff, and Christopher Dawson. ${ }^{3}$

Lewis certainly recognized that the West had entered a period of crisis and he made frequent reference to the European cultural war between the Old and the New-or what I have referred to as the modern kulturkampf. ${ }^{4}$ The meaning and function of Lewis's bursts of combativeness against the forces of the New, however, and the extent of his partisanship with the Old in this regard, is still a matter for debate. ${ }^{5}$

This chapter will examine Lewis's alleged defence of the West during the late 1920 s and early 1930 s by drawing attention to his specifically rhetorical engagement with, and frequent redefinitions of, the kulturkampf between the Old and the New. ${ }^{6} \mathrm{I}$ argue that Lewis vacillated between the rhetorical extremes of this kulturkampf to achieve three primary goals: the creation of ideological balance in the realm of public political discourse, the sowing of critical confusion and controversy, and the intellectual conversion of a select few of his readers. The first goal refers to Lewis's method of internalizing, dirempting, and re-presenting the battling orthodoxies within the

\footnotetext{
${ }^{3} \mathrm{D}$ 'Arcy, The Nature of Belief, 16-7.

${ }^{4}$ Examples of Lewis's use of the terms Old and New can be found throughout this chapter and the rest of this study.

${ }^{5}$ Daniel Schenker, in "Homo ex Machina: Wyndham Lewis on the Definitions of Man," provides a typical example of the problem that should face any critic studying Lewis's politics. He writes that, according to the conventional view of Lewis, "Time and Western Man today lies in the archives like a modern Paradise Lost-a monument to dead ideas-a reactionary bill of particulars sworn out against the twentieth century." He questions, however, the use of the term "reactionary," noting Lewis's protestations against the designation and his seemingly paradoxical fondness for the Russian revolution in The Art of Being Ruled. Schenker, "Homo ex Machina," 102.

'Sue-Ellen Campbell seems to place Lewis's "Enemy" period within the years 1924 to 1934, although she also acknowledges that his Enemy persona did not appear until 1927, with the publication of the first issue of The Enemy. Campbell, The Enemy Opposite, xii-xiii. I am in general agreement with Campbell, although I do not consider Lewis's pre-1927 works, such as The Art of Being Ruled and The Lion and the Fox, to be part of the Enemy-era writings, as the Enemy persona is not fully developed in these works.
} 
kulturkampf as part of an effort to help create "political equilibrium." The second goal is a byproduct of the first: by subjecting ideological orthodoxies to a process of diremption, Lewis was able to frustrate the efforts of ideologically-driven critics to affix permanent political labels to his work. He could thus temporarily assume controversial political stances without declaring partisan allegiances. The third goal follows from the second: by fostering ideological confusion, Lewis aspired, in an evangelical manner, to provoke an ideological conversion in his readers-a transformative experience that would lead them away from ideological orthodoxy and towards an outsider's view of the kulturkampf. There are three particular moments in Lewis's Enemy-era career that emphasize, in turn, each aspect of Lewis's three-pronged rhetorical strategy: his efforts to bring equilibrium to T.E. Hulme's influential model of the kulturkampf; his generation of ideological confusion and controversy in those polemics that figure largely in his battle against the transition group; and the satirical presentation of his own evangelical methods in The Old Gang and the New Gang (1933)-a study of the popular conception of the kulturkampf.

At the heart of Lewis's political writing lies not a reactionary ideological core but a seeming contradiction in his opinions regarding the value of both the Old and the New. Certainly, one of the great obstacles for any critic who seeks to portray Lewis as a reactionary is Lewis's claim, repeated in many of his works, that he is on the side of revolution, or the New. In The Art of Being Ruled, Lewis draws a sharp distinction between "creative revolution" (of which he approves) and "destructive revolution" (to which he is opposed), ${ }^{7}$ but claims to be at root "a man of the tabula rasa both in art and politics," as he states in The Mysterious Mr. Bull, his 1938 study of the British national

\footnotetext{
${ }^{7}$ See Lewis, The Art of Being Ruled, 25.
} 
character. $^{8}$

For Lewis, the average English Tory is largely a figure of fun-a dimwit who is ignorant of the all-pervasiveness of the revolutionary impulse in modern society. In an appendix to book one of Time and Western Man, Lewis notes the impossibility of Tory politics in an age of revolution:

Today everybody without exception is revolutionary. Some know they are, and some do not; that is the difference. Some, indeed very many people, actually believe that they are Tories, for instance. They really imagine that. As it is in nobody's interest, of consequence, to unseal their eyes, and let them know themselves for the humdrum conservative little revolutionaries they are, they remain undisturbed in that belief. So they stay locked in a close embrace with the dullest form of Revolution, convinced all the time that they are defending the great and hoary traditions of their race. ${ }^{9}$

The Tory, from this perspective, is merely a socialist-in-denial, a pseudo-conservative who has unconsciously accepted the tenets of modern socialism, and who helps to make the modern transition palatable by clinging to the superficial symbols of a long-dead past. Despite his criticisms of the Tory mind and of the efficacy of the Tory political stance, Lewis grudgingly admits, in the later The Mysterious Mr. Bull, that conservatism performs a necessary function. In that work, Lewis suggests that some form of pseudoreaction or pseudo-conservatism is perhaps acceptable, if only as a means of avoiding a constant succession of faulty New Jerusalems:

History presents itself to me as a tale told by an idiot. Most "tradition" appears

\footnotetext{
${ }^{8}$ Lewis, The Mysterious Mr. Bull, 230.
}

${ }^{9}$ Lewis, Time and Western Man, 118. 
to me to be merely a bad tradition. Our prescriptive heritage of notions and standardized reactions I am prone to regard as so many crystallized mistakes, or of humbug built up into a stolid fairyland of error.

.. Gladly would I subscribe to-morrow to the scrapping of every human institution-and as to national institutions, they are merely the local form of a universal shortcoming.-Gladly would I cast my vote for, and assist at, this bonfire-if it were not for one thing.

Having, by universal consent, "shattered it to bits," who would it be who would then proceed to build our society "nearer to the heart's desire"? Whose "heart's desire" would it be that would raise the New Jerusalem?

... The answer is shattering. There is no shadow of doubt that just the same sort of people who brought into being and handed down to us the nonsensical system we have got would be employed in the erection of the New Jerusalem. Or that would apply in nine cases out of ten-for there are such things as genuine revolutions. ${ }^{10}$

Conservatism, Lewis implies, even if it is based on faulty premises, has the potential to act as a safeguard; thus, it is not an insignificant cultural force. The two different opinions regarding conservatism that Lewis offers in Time and Western Man and The Mysterious Mr. Bull-conservatism as the "dullest form of Revolution," and conservatism as a safeguard against misguided or destructive revolutionary impulses-are not necessarily contradictory. In Lewis's view, tradition and revolution occupy opposite ends of the spectrum of modern revolution in general, existing in a state of constant dialectical

${ }^{10}$ Lewis, The Mysterious Mr. Bull, 230. Lewis's quotations in this passage are taken from the Rubaiyat of Omar Khayyám. 
tension-a tension with the potential to be both creative and destructive.

Lewis's cautious approval of conservatism figured largely in his thought throughout his career; it appears again, for example, in the Canadian-published Anglosaxony: A League that Works (1941), where he states that "However much we might desire it we cannot have a tabula rasa. We cannot build up from the base, politically; all we can do is to alter as we go along, adapt, and, as we believe, improve."11 In that work, despite confessing that he is "of a radical cast of mind," he adds the following: "But experience has taught me this: that a community, tribe, or nation, grows like a tree. Its past is as real as its present, often much more real; radical changes cannot be imposed upon it arbitrarily."12

Even if Lewis's valuation of conservatism was highly qualified, he nevertheless saw the conflict between tradition and revolution as central to modern culture, and even, as he suggests in The Mysterious Mr. Bull, the most fundamental cultural divide of the twentieth century. Lewis writes that "The division of opinion in our time is generally represented as a struggle between the Rich and the Poor," but disputes the centrality of this antinomy, stating that "The actual conflict is a little difficult to define, but it may best be described as a conflict between the Old and the New."13 The turbulent political landscape of 1930s Europe, Lewis suggests, is the result of a conflict between these two principles: "The 'New' and the 'Old' co-exist. They clash. They make a cacophonous nonsense of everything." 14

Lewis's terminology for discussing the twentieth-century cultural divide is rooted

\footnotetext{
${ }^{11}$ Lewis, Anglosaxony: A League that Works, 72.

${ }^{12}$ Ibid.

${ }^{13}$ Lewis, The Mysterious Mr. Bull, 220.

${ }^{14}$ Ibid., 222.
} 
in the distinction between the Old and the New, but in all of Lewis's work, these categories are not entirely stable, and are subject to modification. It is to Lewis's credit that he was not dogmatic in his use of dichotomies as analytical devices, despite his penchant for binary thinking. Indeed, a glance at the variety of reactionary discourses in the early twentieth century shows that the exact nature of the Old/New division in modern thought was not susceptible to precise definition. Irving Babbitt and Charles Maurras tended to define it as a conflict between classicism and romanticism. ${ }^{15}$ T.S. Eliot, in After Strange Gods (1934), described it as a conflict between orthodoxy and heresy. ${ }^{16}$ Charles Ferrall, in Modernist Writing and Reactionary Politics, equates it with the ancients versus moderns division of the Battle of the Books, as did Lewis himself. ${ }^{17}$ In The Mysterious Mr. Bull, Lewis expands upon the distinction between the Old and the New by adding that the cacophony it creates is best comprehended by labelling the political factions involved with either the black label of nationalism or the white label of internationalism. In this scheme, the Old receives a black label and the New a white label. ${ }^{18}$ The chain of related dichotomies that Lewis invokes, namely the Old versus the New, nationalism versus internationalism, and Black versus White, is continued when Lewis examines the dichotomy of the conservative mind versus the ahistoric (or revolutionary) mind, as represented by Edmund Burke and William Godwin, respectively. ${ }^{19}$ In a later chapter of The Mysterious $M r$. Bull, he summarizes the

\footnotetext{
${ }^{15}$ See Babbitt, Rousseau and Romanticism, 16-38, and David Carroll on Maurras in French Literary Fascism: Nationalism, Anti-Semitism, and the Ideology of Culture, 71-96.

${ }^{16}$ Eliot, After Strange Gods, 21-22.

${ }^{17}$ Ferrall, Modernist Writing and Reactionary Politics, 1-2. See also the introduction of the present study.

${ }^{18}$ Lewis, The Mysterious Mr. Bull, 223.

${ }^{19}$ Ibid., 225-228.
} 
characteristics of these dichotomies as a whole, and his relation to them, again utilizing the label metaphor:

Had you come upon me in my cradle, you would have had to use for me your whitest label. To-day you would have to use one half black, half white. . . The white label stands for the New. ... Also it stands for Abstract Order. A Catholic, for instance, must have a white label as much as an international financier. It represents the white sheet of paper, before it has been written on.

The black label stands for the Old-that is to say the organic, the historic. It also stands for Nationalism, which is the militant expression of the organic continuity of the race, as opposed to the mere present. A black label stands for all that is concrete (coloured and well furnished): for the sheet of paper scribbled over by a hundred hands, from generation to generation. Yet of course to-day a great deal of nationalism is revolutionary, and there are numbers of fairly white men going about in pretty dark shirts. ${ }^{20}$

Here, in his description of the Old, Lewis is referring specifically to traditionalist conservatism (of the Burkean variety). Confusingly, Catholicism is designated as representative of the New (in that it stands for a universal system of values rather than a localized tradition) despite its association with Old Europe.

The implications of the last sentence of the passage quoted above apply to Lewis as well: he can be counted as a "white" (revolutionary) man in a "dark" (reactionary) shirt. The inherently controversial nature of Lewis's conflicted and contradictory stance in relation to the kulturkampf is amplified in the image Lewis invokes of the iconic

\footnotetext{
${ }^{20}$ Ibid., 264.
} 
"blackshirts" of the Italian and British fascist movements, or perhaps the "brownshirts" of the Nazis. This type of ambivalent posturing, with all of its controversial implications, is characteristic of Lewis's writing of the 1920s and 30s, and his Enemy period in particular.

Reactionary thought in the twentieth century often seems to be born less from a genuine longing for the Old than from a perverse desire to contradict the pieties of liberalism and progressivism. Such was certainly the case with the amateur philosopher T.E. Hulme, who developed an important early model of the kulturkampf that influenced many of the British and Anglo-American modernists. Lewis was closely associated with Hulme in the years leading up to World War I, and although he was often critical of his friend, the Hulmean view of history constitutes a standard to which Lewis frequently refers implicitly-especially in his Enemy-era writings. Thus, Lewis's engagement with Hulme's writings may serve as a preliminary example of how Lewis sought to maintain a seemingly contradictory and paradoxical position within the kulturkampf during his Enemy period, as well as the strategies he employed to break down the friend/enemy divisions of the political.

Hulme's work (apart from his influential translations of Henri Bergson and Georges Sorel) consists mainly of articles written for journals-especially A.R. Orage's The New Age-and it was only in 1924 that a smattering of his published works and unpublished notes were edited by Herbert Read and published as Speculations. The central debate that Hulme outlined is not entirely clear in its details, and many contradictions emerge across the span of his writings, but the nucleus of his political 
thought is contained in a series of 1912 essays published in The Commentator, collectively titled "A Tory Philosophy." In these essays, Hulme describes himself as "a certain kind of Tory"21 and outlines what he claims is an emerging central dichotomy in modern thought: the division between the classical and the romantic worldviews. This dichotomy is structured around the question of whether humanity is irrevocably tainted by original sin, which is the classical opinion, or fundamentally good, which is the romantic one. ${ }^{22}$ According to Hulme, one's answer to this question determines one's entire worldview. ${ }^{23}$ If man is inherently sinful, then he needs traditions and unchanging moral codes in order to cleave to the good. If man is inherently good, then traditions and moral codes are simply arbitrary constraints that keep him from developing his inherent goodness (an attitude perhaps exemplified by Jean-Jacques Rousseau's famous statement, "Man was born free, and he is everywhere in chains"). ${ }^{24}$ For Hulme, these are not merely two possible theological stances, but two ideas of culture and civilization built upon fundamentally opposing premises.

C.D. Blanton, in a 2006 essay on Hulme entitled "The Politics of Epochality: Antinomies of Original Sin," offers an elegant interpretation of the development of Hulme's ideas from the classicism versus romanticism debate to his eventual espousal of a new medievalism that was meant to function as an antidote to humanism and humanitarianism:

With each turn [of his "series of antinomies" from 1912 to 1915] Hulme expands

\footnotetext{
${ }^{21}$ Hulme, "A Tory Philosophy," 187.

${ }^{22}$ Ibid., 189-191.

${ }^{23}$ Hulme remarks, "In however many ways these two points of view differ, you can always in the end trace it back to this quite simple difference in their conception of the nature of man." Ibid., 191.

${ }^{24}$ Jean-Jacques Rousseau, The Social Contract, 49.
} 
the orbit of his oppositions, first absorbing romanticism and classicism as surrogate political terminologies, stylistic registers of liberalism or conservatism respectively, only to recast those political positions again in the antinomy between humanism and its opposite. Through it all, however, Original Sin remains the axis and dividing line of Hulme's later thought, the one constant around which other terms array themselves. ${ }^{25}$

As Blanton suggests, Hulme's antinomies are not discrete entities, but variations on the theme of two conflicting attitudes springing from the two possible answers to the question of original sin. Such theologically-based dichotomies were not uncommon in conservative thought of the early twentieth century (even in England, as shown in the work of G.K. Chesterton in particular), ${ }^{26}$ but what separates Hulme from the stereotypical reactionary is that his "Toryism" developed as a modification or inversion of the radical thought of Friedrich Nietzsche, Henri Bergson, and Georges Sorel. Hulme accepted modernity as a fact and sought to reinvigorate both ancient philosophy and Christian thought without engaging in a naive adherence to the past.

Hulme also possessed a strong understanding of the rhetoric associated with the antinomies he delineated. In "A Tory Philosophy," he describes a technique used by the Boxers of the Chinese Boxer Rebellion to secure adherents: the teaching of phrases called "words of power" that were used as mantras to inspire bravery and unity before battles. ${ }^{27}$ Hulme argues that British political parties also use "words of power"; some

\footnotetext{
${ }^{25}$ Blanton, "The Politics of Epochality: Antinomies of Original Sin," 199.

${ }^{26}$ See, for example, Chesterton's Orthodoxy (1908), in which he states, "If we wish to pull down the prosperous oppressor we cannot do it with the new doctrine of human perfectibility; we can do it with the old doctrine of Original Sin." Chesterton, Orthodoxy, 140.

${ }^{27}$ Hulme, "A Tory Philosophy," 187.
} 
examples of the "epithets" of political romanticism that Hulme offers in "A Tory Philosophy" are progress, liberty, equality, and universalism. ${ }^{28}$ These words are signifiers that become charged with meaning through repeated use, and eventually take on the character of fixed and unquestioned sources of value and energy. As a result, partisans of one side of the political divide cannot fully understand the "catchwords and phrases" of the other, for when these words are drained of their emotional punch, they become detached signifiers, or mere words: ${ }^{29}$ "Generally, these phrases are only 'alive' to one side. To the other they appear to be mere empty clichés. What I am trying to do in this article is to set out the kind of emotion which vivifies for me certain expressions which to you, if you are progressives, appear to be shrivelled up and empty, meaning nothing; and at the same time to pick out the sentiments on your side which appear to me to be loathsome and disgusting. ${ }^{n 30}$

Hulme's analysis, despite its partisan bias, offers insight into the polemical mechanics of the kulturkampf, offering a model not only of its structure, but of the political conversion-experience that can occur inside its confines. For the mainstream citizen of a progressive society, words like progress and liberty appear "alive," but can easily become "shrivelled up and empty" or even "loathsome and disgusting" if that person's semiotic reality is damaged in any way. At such a juncture, words like tradition or duty, which previously would have seemed to be "empty clichés," may rise up and take their place as charged signifiers.

In "Humanism and the Religious Attitude," Hulme puts forward the idea that

\footnotetext{
${ }^{28}$ Ibid., 194-95.

${ }^{29}$ Ibid., 187.

${ }^{30} \mathrm{Ibid} ., 187$.
} 
periods of cultural transition involve a mass shift or conversion from one worldview or weltanschauung to another, and that, crucially, there always exists the potential for such shifts to be reversed. Anticipating Lewis's The Lion and the Fox, Hulme uses the Renaissance as an example of a period of cultural transition:

Consider the most obvious example of the emergence of a new Weltanschauung-the Renaissance. You get at that time the appearance of a new attitude which can be most broadly described as an attitude of acceptance to life, as opposed to an attitude of renunciation. As a consequence of this, there emerges a new interest in man and his relationship to his environment. With this goes an increasing interest in character and personality for its own sake, which makes autobiographies such as that of Cellini possible for the first time. An autobiography for its own sake would have been inconceivable before.

Though these are platitudes, yet their real significance is entirely missed by people who do not see this change as a change from one possible attitude to another, but as a kind of discovery, like that of gravitation. They thus fail to realise the possibility of a change in the contrary direction, and also to understand the real nature of such attitudes. ${ }^{31}$

As Hulme points out, this observation may seem simplistic, but it has larger, more complex implications. If one sees humanism as merely an "attitude," and not an inevitable historical development, then it becomes possible to see anti-humanism as an equally valid weltanschauung. At the root of each weltanschauung, Hulme claims, lies not an absolute truth, but a principle or idea that provides emotional satisfaction to those

\footnotetext{
${ }^{31}$ Hulme, "Humanism and the Religious Attitude," 25.
} 
who adopt it. Science and philosophy are used to extend, justify, and solidify this source of satisfaction. ${ }^{32}$

The idea of a reversal of the modern weltanschauung was of more than historical interest for Hulme, for in his mind, humanism had already reached its zenith and become sterile; in other words, for Hulme and those who shared his attitudes, it had ceased to provide satisfaction. The most accessible alternate source of satisfaction lay in its longdormant extreme opposite: anti-humanism. For Hulme, anti-humanism took the form of a neo-medievalism that denied the importance of earthly life, while for others it took the forms of neo-scholasticism, neo-classicism, neo-confucianism, or the various types of fascism. ${ }^{33}$ The anti-humanist weltanschauung could be recovered and articulated by searching for the mirror-opposite of every tenet of modern humanism. Thus, reaction in its many forms became for these anti-humanists a new potential source of excitement, energy, and satisfaction. The Hulmean kulturkampf is a battle between two radically different weltanschauungen, and Hulme's vision of his own historical moment is not simply one of the New replacing the Old, but rather of a mortal conflict between humanity's past and future.

Lewis's vision of the kulturkampf corresponds in many respects to Hulme's, although there are some crucial differences that highlight the originality of Lewis's political stance. Lewis was a close associate of Hulme before World War I, but his later references to Hulme in Men Without Art and Blasting and Bombardiering (1937) express

\footnotetext{
${ }^{32}$ Hulme refers to the study of such idea-structures as a "critique of satisfaction." Ibid., 12-23.

${ }^{33}$ The range of anti-humanist thinking in the first part of the twentieth century is far too expansive to catalogue here. In Lewis's time, neo-scholasticism was represented by Jacques Maritain among others, neo-classicism by Charles Maurras, and neo-confucianism (if it can be called that) by Ezra Pound. The representatives of fascism, of course, range far and wide. A good starting point for any investigation into the history of fascism is Eugen Weber's Varieties of Fascism (1964).
} 
skepticism regarding Hulme's ideas. ${ }^{34}$ In his chapter "Hulme of Original Sin" in Blasting and Bombardiering, Lewis is especially critical of Hulme, but credits him for his powerful use of the idea of original sin, stressing its originality within the confines of England at the time. The idea itself does not impress Lewis, and he refers to Hulme's "discovery of Original Sin" as "the least of his achievements," adding that "Probably he came across it while reading some primer of Scholasticism." ${ }^{35}$ However, he adds, "it was extremely original of this Mr. Hulme-especially living as he did in Mr. Polly's England-to pick out this stuffy old doctrine of Original Sin and rub everybody's nose in it. ${ }^{936}$ Thus, the doctrine was nothing new, but its use as a divisive principle, thrust into the midst of a society devoted to progress and the perfection of man, was a unique phenomenon.

Unlike Hulme, Lewis refused to align himself with any "Tory Philosophy" based on the idea of original sin. Although he certainly tended towards classicism in both his writing and his visual art, his position in the Hulmean kulturkampf remained ambivalent. This ambivalence is most apparent in his lengthiest response to Hulme, namely a chapter in Men Without Art entitled "The Terms 'Classical' and 'Romantic."” In that chapter, Lewis rejects the classical/romantic distinction and exposes the many contradictions that arise when it is applied dogmatically. Part of his argument is that true classicism simply cannot exist in modern society, given that the conditions necessary for classicism (such as those that existed in seventeenth-century Europe) are impossible to establish in the age

\footnotetext{
${ }^{34}$ Lewis, Blasting and Bombardiering, 99-104.

${ }^{35}$ Ibid., 101-2.

${ }^{36}$ Ibid., 104.
} 
of the mass man. ${ }^{37}$ Lewis is resigned to the impossibility of recapturing the past, remarking that "Just as [British politician] Sir John Simon states, 'We are all Socialists today,' so in matters of art it could be said, 'We are all romantics today,' with at least equal truth. ${ }^{.38}$

Later in his chapter on Hulme, Lewis expands upon the idea of the allpervasiveness of romanticism and the revolutionary attitude, suggesting that because all battles between the Old and the New must take place within a revolutionary context, no authentic "change in the contrary direction" for the weltanschaung is possible:

Just as (I agree) we are, undoubtedly, on all hands slipping back into the old narrowly European grooves, under the straitening pressures of the Slump, into economic and political nationalism: and, in the bosom of nationalism, into the old Tory-Whig, Catholic and Protestant antagonisms: so we are bandying about these words "classical" and "romantic." But it is all extremely artificial-as artificial, for instance, as the Erse names in which the Irish at present masquerade. Soon we shall be expected to yodel in middle English, and then the man of the Danegelt will be incomprehensible to the man of the Saxon-south. All these things hang together-it is the end of history, and the beginning of historical pageant and play. But we are all compelled, to some extent, to enter into the spirit of the comedy-that is the humble message of this book. ${ }^{39}$

Here Lewis suggests that reactionary classical thought is not the powerful alternative to

\footnotetext{
${ }^{37}$ Lewis writes that "No 'highbrow' set, in a great metropolis like London or Paris, can for a moment supply the same order of framework that was forthcoming for the artist of the Augustan age, or the homogenous, compact society behind Dryden, Pope and Swift, or the Paris court-world for whom Racine and Molière wrote." Lewis, Men Without Art, 154.

${ }^{38}$ Lewis, Men Without Art, 157.

${ }^{39}$ Ibid., 165.
} 
romantic revolution that Hulme and those like him make it seem. On the contrary, its revival shows that revolution has already triumphed; "reaction," in its twentieth-century manifestation, is simply another form of romantic longing, Lewis implies, and can only function as a replica of a past that has been permanently uprooted. Significantly, Lewis invokes the Hegelian idea of the end of history, suggesting that in a world in which no historic (or history-changing) actions on the part of man are possible, ideas from the past are only useful as a means of fostering artificial conflicts, as part of a new era of "historical pageant and play."

The idea that in the twentieth century the past cannot be resuscitated into something living and authentically historical is one that Lewis emphasizes in Men Without Art. One of his areas of focus, for instance, is the then-flourishing revival of the thought of Thomas Aquinas by the neo-scholastics or neo-Thomists-a group of scholars with intellectual ties to both neo-classicism and Catholic orthodoxy. Although Lewis sympathizes in certain respects with the neo-scholastics, he realizes that a resuscitated scholasticism will be very different from its long-dead original. He writes (with reference to both Hulme and the late nineteenth-century French neo-classicist Ferdinand Brunetière), 'If . . . you have 'come through romanticism,' are acquainted with German and French pessimism, have perused Beyond Good and Evil, and have taken shelter at last beneath the wing of an archangel, your Christianity, like Brunetière's-or your 'classicism,' as Hulme specifically foresaw-will scarcely look quite as it would have done under more orthodox circumstances. ${ }^{240}$ In other words, there is a great difference between a medieval scholastic and a modern neo-scholastic, even if they embrace the

${ }^{40}$ Ibid., 170. 
same ideas. Neo-scholasticism and neo-classicism, Lewis implies, are forms of romanticism themselves, representing a longing for absolute values as means of escaping the flux of the present. As Lewis points out, Hulme recognized the romantic foundations of neo-scholasticism and neo-classicism to some extent, but this insight did not stop Hulme from promoting classicism as an authentic alternative to romanticism.

Another aspect of Lewis's critique of Hulme that sheds light upon Lewis's relation to the kulturkampf is his treatment of the concept of original sin. Although Lewis shares Hulme's view of humankind's failings, he neither denies the existence of original sin nor affirms it; he evades answering the supposedly fundamental question of original sin by simply refusing to grant it any importance. He states, "With Hulme I am in complete agreement regarding which of those two conceptions-namely, the conception of man as a static animal, needing a great deal of polishing up to appear at his best, on the one hand, and the conception of man as a god-like and infinitely 'progressive' animal on the other-is to be preferred." ${ }^{41}$ He qualifies this statement, however, by asking, "And then why must 'sin' play, although in the European past it has, such a predominant rôle? It does not matter very much. But the dogma of original sin happened to play that humbling part at that moment [of cultural transition between medieval and Renaissance Europe], he tells us; nevertheless, it is possible to feel the same humility, with less dogma than that requires. ${ }^{\prime 42}$ There are other ideas, Lewis suggests, that can "play that humbling part" and make humans consider themselves inherently flawed, and he sees no reason why the idea of sin should be so central to this conception. Commenting on Hulme's

\footnotetext{
${ }^{41}$ Ibid., 167.

${ }^{42}$ Ibid., 167.
} 
assertion that belief in God is a natural instinct, Lewis remarks, "I would not argue with that; but I would say that the dogma of original sin is not as deep an instinct as that of self-preservation, or as God. In fact, is it an instinct at all? I hope not, for I have not got it. ${ }^{43}$

Lewis's aversion to moralism-something that remained consistent throughout his career until his religious awakening before his death-is more than just an expression of a personal bias against the strictures of religion. Lewis refuses to answer the question of original sin, which is a moral question that demands a clear answer, because he wishes to remain outside the essentially unresolvable classicism/romanticism debate despite his obvious preference for classicism; instead of taking sides on the issue, Lewis attempts to bring the debate into a state of Proudhonian "unstable equilibrium," so that there is less potential for stifling orthodoxies to form. Thus, within the confines of the debate as it is absorbed and re-articulated by Lewis, the neo-classical or neo-scholastic view of man is tempered by Lewis's claim for the relative unimportance of sin.

Lewis's defusing of the Hulmean kulturkampf, which he accomplished by simply ignoring the fundamental question it posed, provided Lewis with a rationale for both political vacillation and the formation of temporary political allegiances. Although, according to Lewis, the course of revolution is inescapable, the artificial conflicts that constitute the kulturkampf may be guided in such a way that they offer a means not merely of fueling conflict, but of "influencing the [cultural] integration" that will take place after the current period of transition (to use the terminology of his 1932 work,

\footnotetext{
${ }^{43}$ Ibid., 168.

${ }^{44}$ See chapter one of the present study for a discussion of the idea of political equilibrium in relation to Lewis's work. The idea of a political "unstable equilibrium" is taken from Proudhon's Justice in the Revolution and the Church (1858). Proudhon, Selected Writings, 229.
} 
Doom of Youth). ${ }^{45}$ If one reads Lewis without taking into consideration his assertion that

all cultural conflicts at the end of history constitute a form of "play," then one must come

to the conclusion that he was an inherently contradictory figure, torn between absolutes.

However, if one takes into consideration his defusing of the kulturkampf, his reactionary

statements become strategic utterances rather than assertions of belief; he uses the

contradictory force of reaction as a tool to curb revolutionary excess and to shape the

future.

Lewis's ambivalent relation to the Catholic Church, which is seen by many to be

an unambiguously reactionary institution, may serve as an example of the way in which

Lewis adopted seemingly contradictory positions within the conflict Hulme outlined,

while at the same time articulating the principles of a potential equilibrium between

opposing political forces. ${ }^{46}$ This strategy is most apparent in Time and Western Man. As

\footnotetext{
${ }^{45}$ In Doom of Youth, Lewis raises the possibility of a future cultural integration after the current period of cultural disintegration:

Disintegrated into a thousand class-warring factions-analysed back into its composite cells, and incessantly stimulated to one huge destructive civil broil-the Occident is much too far gone ever to recover, upon its old lines, even if we desired it. We are here, therefore, taking Occidental disintegration for granted.

In the back of our minds it is admissible to entertain some picture of a future integration. And for my own part, the more novel it was the better I should like it. But the disintegration is already very far advanced: the new integration even has long ago begun. Such a book as this is primarily intended to influence the integration. (Certainly it is not intended to arrest the disintegration.) In what manner does it wish to influence the integration? Principally in such a manner as to prevent the mere destructive technique of the transition from being taken too seriously, and so to avoid a great many false and puerile passions and modes of thought—or unthought—from being taken up into the body of the new synthesis.

Lewis, Doom of. Youth, 62-63.

${ }^{46}$ The Catholic church was certainly seen as the epitome of reaction by the forces of Republican Spain during the Spanish Civil War. When fighting began, the church was one of the first targets, and Republican militias carried out a campaign of persecution, which included church burnings and the execution of an alleged 6,832 bishops, priests, nuns, and monks. See Hugh Thomas's The Spanish Civil War (1961), pages 227-232. Lewis recognized that the church was perhaps the most important representative of one extreme in the kulturkampf, stating in 1934 that "The two most weighty figures in the world today (I do not say tomorrow) are the Pope and the Marxist Dictator; they alone are consistent, they alone are ubiquitous, and mean the same thing in one place as in another." Lewis, Men Without Art, 187.
} 
Paul Edwards notes in his survey of the critical reception of Time and Western Man,

"Catholics welcomed, with reservations, Lewis's limited endorsement of Thomism (and

James Joyce believed that Lewis was about to make a 'clamorous conversion')."47

Indeed, in Time and Western Man, Lewis writes that "Constantly in our criticism we march with the "thomist',"48 and many of the targets of his criticism are similar to those of the neo-scholastics and Catholic cultural criticism as a whole. ${ }^{49}$

Despite Lewis's apparent declaration of friendship with the neo-Thomists and his general sympathy with their critical position, he makes it clear that this is an alliance of convenience, forged simply because the neo-Thomists are the only active and articulate group of intellectuals functioning outside of revolutionary orthodoxy:

In opposition to the "modernity" they [the neo-Thomists] attack (and everything is "modern," and therefore to be attacked, which is not thomist or aristotelian, for the typical contemporary catholic theorist) is, in their system, "antiquity," which is equivalent to the "Classical" of Spengler, and is just as inalterable, unique and fixed. Those are the two extremes of contemporary controversy: indeed, when we said there was no "opposition" today, that would, in this sense, be inexact: for there is, of course, always the catholic opposition..$^{50}$

Lewis realizes that this "catholic opposition" represents an orthodoxy with the power to be just as constraining to the intellectual as any; the rigid oppositional pose that makes it

\footnotetext{
${ }^{47}$ Edwards, "The Critical Reception of Time and Western Man," 509.

${ }^{48}$ Lewis, Time and Western Man, 361.

${ }^{49}$ Jacques Maritain's first major work, La philosophie bergsonienne, anticipates the central argument of Time and Western Man by over a decade. Although he eventually warmed to Henri Bergson's ideas, La philosophie bergsonienne describes a stark divide between the principles of traditional Catholic philosophy and the then-fashionable theories of Bergson, who is also the primary target of Time and Western Man.

${ }^{50}$ Lewis, Time and Western Man, 361-2.
} 
valuable is also its greatest fault. Lewis complains that neo-scholasticism "is incurably 'conservative': it is forever the 'old' against the 'new'." Like most orthodoxies, it is uncritical in regard to its own principles:

[Neo-scholasticism] says many shrewd and damaging things about "modernism": but because all that is contemporary (except thomism) is vowed-such is its unanimity and herd-discipline-to silence about anything that is not very delightful or intelligent about "modernity," that is no reason why the epoch and the ideas that produced scholasticism, to which catholicism points, should be wholly beautiful and true..$^{51}$

Due to his skepticism regarding the value of the Old, Lewis is willing to support neoscholasticism in order to wield temporarily its power, but has no intention of becoming a neo-scholastic. In other words, he refuses to form an authentic political friendship with the neo-scholastics in the Schmittean sense.

Lewis's attitude towards Catholicism remained unchanged for most of his career. Its representatives were, for Lewis, strategic allies. In Men Without Art, for example, he claims that his only reason for siding with the neo-Thomists on certain issues is to counter what he sees as the fanaticism of Protestant moralism, which he associates with progressive, egalitarian thought. Here he contrasts the "moralists" (the revolutionaries) with the "religionists" (the New Humanists and the neo-Thomists) and cynically aligns himself, as an artist, with the latter:

The moralist is, it is generally conceded, one of the most troublesome enemies the artist has at normal times (it was the moralist closed down the theatres and

${ }^{51}$ Ibid., 362. 
brought to an abrupt end the Tudor drama-the stock historic illustration): and here we have in the up-to-date religionist (I refer to the sham and flashy, the propagandist type), an enemy of the moralist, just as the latter is of the artist. It is desired to keep the moralist in his place! But we want to do that too. Here is a situation of which some use surely can be made. Every support should be forthcoming for these chilly, snobbish, anti-human sectaries. For their pigdin is ours as well! $!^{52}$

Supporting the neo-Thomists is advantageous, Lewis suggests, because they may help to control the tide of revolution; beyond that, they have the potential to be dangerous.

Lewis's goal in supporting neo-scholasticism in Time and Western Man and Men Without Art is to level the playing field within the intellectual sphere of the kulturkampf, in order to show that there is an effective, if flawed, intellectual alternative to revolutionary orthodoxy: an intelligent defense of the Old. The representatives of the New, in other words, will have to wrestle with a type of critic far more sophisticated than the stereotypical Tory.

Lewis's grand vision of equilibrium-the intended result of his strategic support for Catholicism-is summarized in a single passage from Time and Western Man:

We should support the catholic church perhaps more than any other visible institution: but we should make a new world of Reason for ourselves, more elastic than the roman cult is in a position to supply, and employing all the resources of the new world to build with. Outside we can actually assist that church more than

\footnotetext{
${ }^{52}$ Lewis, Men Without Art, 176.
} 
we could within it, if we were, otherwise, inclined to such a communion. ${ }^{53}$

Lewis's ultimate goal is to fuse the best of the Old and the New and build, in a creatively revolutionary manner, "a new world of Reason." Catholicism, despite its clear attachment to the Old, has as much potentially universal appeal as revolutionary ideology, and a fusion or balance between the two might provide a moral and intellectual framework for a new Europe, or even a new global society.

For Lewis, ideological vacillation served other purposes besides the creation of a prospective political equilibrium. In many respects, it also served as an engine of confusion and controversy. ${ }^{54}$ This aspect of his larger strategy becomes especially apparent when his work is seen in light of the reactions of some of his critics. Although Lewis attempted to remain strictly non-partisan during his Enemy period, his harnessing of reactionary rhetoric was sometimes cited as evidence of an underlying reactionary temperament, and there is evidence that on some level, Lewis courted this type of literary controversy among critics hoping to discredit him within the largely left-leaning world of British art and literature. Once his critics had taken the bait, Lewis could artfully deny their allegations and plead his case for the artist-intellectual outsider.

Lewis's public feud with the avant-garde transition journal is one of the most

\footnotetext{
${ }^{53}$ Lewis, Time and Western Man, 367.

${ }^{54}$ Sue-Ellen Campbell does acknowledge this aspect of Lewis's work. Commenting on Lewis's references in The Art of Being Ruled to Nietzsche's relation with his audience, she remarks that "Like Nietzsche, the Enemy stands alone against his culture; like Nietzsche, Lewis exposes himself to misunderstanding-indeed, courts it-by the passionate intransigence of his opposition." Campbell, The Enemy Opposite, 46.
} 
important examples of.Lewis's facilitation of controversy. ${ }^{55}$ The first stone in the Enemy/transition conflict was thrown by Lewis in 1927 in the pages of The Enemy, ${ }^{56}$ and the response it elicited was the aforementioned "First Aid to the Enemy" by the transition editors Jolas, Paul, and Sage. Lewis fought back in 1929 by publishing "The Diabolical Principle," which focuses on transition and their comments, in the next issue of The Enemy; it later appeared in book form (with "The Dithyrambic Spectator") in 1931.

"First Aid to the Enemy," despite being overtly polemical, is one of the most penetrating, and humorous, appraisals of the Lewis enterprise. The transition editors appropriate Lewis's critical techniques, using satire to reveal his weaknesses and apparent insecurities. Their central thesis is that Lewis is essentially a British conservative of the ordinary variety, who once attempted to ape the avant-garde but is no longer able to keep up with the changing times. As a result, he has turned against the movement with which he once aligned himself, and in his late-1920s incarnation has become "the British Messiah," and "elected himself the Defender of the Western World." ${ }^{957}$ He still appears, superficially, to be a "brilliant young warrior," but underneath

\footnotetext{
${ }^{55}$ Andrzej Gąsiorek, in Wyndham Lewis and Modernism, provides a brief examination of Lewis's battle with transition. Gasiorek, Wyndham Lewis and Modernim, 39-42. The most extensive examination of the Enemy/transition debate can be found in Julian Hanna's "Blasting After Blast: Wyndham Lewis's Late Manifestos," which places the writings in question within the genre of the manifesto.

${ }^{56}$ The offending material is likely that included in Lewis's editorial notes from The Enemy 2 . In a section of his notes entitled "Art and 'Radical' Doctrines"' (on pages xxiii-xxviii) Lewis offers a provocative critique of transition and its alliance with surrealism. Lewis writes, "What I accuse such a paper as Transition of being, then, is a political paper essentially: all the rest that is found there is 'literature,' or art-generally the art of such people as Picasso or Chirico, that you can call 'Super-realist' or anything else you like, but your calling it so will have no meaning except as an imported advertisement of what you are yourself-which in the case of the transitionist certainly is not an artist, but that kind of objectionable hybrid, an extremely 'artistic' mondain revolutionary fanatical politician." Lewis, "Editorial Notes," xxvii.

57"First Aid," 163.
} 
it all, the writers claim, "Mr. Lewis is about seven tenths bluff." ${ }^{" 58}$ Functioning within the strict friend/enemy dichotomy of the kulturkampf, the transition editors attempt to determine what they believe are Lewis's true political friends by noting his list of enemies:

Yes, Mr. Lewis, in spite of his positivist attitude, his brave attacks, his thumping epithets, is somewhat of a bluff-and a pitiful one at that. For he sets himself up as a radical; proudly he repeats that he is an "enemy," and "outlaw." The rebel instinct-there can be no doubt of it-is strong in him; but, alas, the complacent, salt-of-the-earth, status-quo-upholding tradition of the British is bred into his bones.

... Look once again at the list of this "outlaw's" victims-Communism, Surrealism, transition, James Joyce, Gertrude Stein, Indians, Negroes, Sherwood Anderson, D.H. Lawrence, etc. How exactly they coincide with the hatreds of the deeply intrenched nobility, the solid M.P., the British critic and commentator, the conservative middleclass newspaper reader. Gouge the camouflage out of The Enemy and you will have the London Times sputtering with virtuous indignation about Russia's plans to dynamite the British Isles. ${ }^{59}$

Lewis is described as a conservative by nature, in that the mishmash of prejudices that comprise British tradition are "bred into his bones." The transition editors are unable to determine the exact nature of Lewis's alleged "defence of the West," but assert that "for the purposes of our orientation we probably do not go wrong if we assume that Mr.

\footnotetext{
${ }^{58}$ Ibid., 164.

${ }^{59}$ Ibid., 165.
} 
Lewis leans toward the Neo-Thomist ideas and coincides in this with the theories of Massis, Maritain, Cocteau and others of that group. He refuses, however, to accept the dogmatic conclusions of these men." ${ }^{60}$ This lack of a clear moral and political framework, they imply, is a serious flaw in his approach. They ask, "What is this much vaunted Western world which Mr. Lewis regards as of such high historic importance? Is it the Catholic tradition? Is it Graeco-Latin civilization? Is it the Anglo-Saxon hegemony?"61 Lewis's cautious allegiances are mistaken for vague and irrational prejudices, and the transition portrait of Lewis is one of a deeply conservative man pretending to be a free-thinker.

In "The Diabolical Principle" Lewis denies the accusations of the transition editors and launches a counter-attack in which he, in turn, appropriates their polemical techniques. His central strategy is to assert his own independence from reactionary politics-or any politics at all-while showing that the transition editors are not the freethinkers they claim to be. He pays special attention to the superficial aura of detachment and levity in the transition piece, referring to the article as a "puppet-game" and claiming that "although these performers pretend to be lounging about against lamp-posts and enjoying the fun, they are really confederates and have pieces of thread going into their pockets. ${ }^{962}$ Lewis's criticism here is accurate. In their article, the transition editors claim to "care not a hoot for political activities," 63 and state that, although they possess a "warm feeling" for Surrealism and Communism, "It is our purpose, purely and simply, to amuse ourselves in weeding out the rank and sterile growth that has sucked the life out of

${ }^{60} \mathrm{Ibid} ., 165-166$.

${ }^{61}$ Ibid., 166.

${ }^{62}$ Lewis, "The Diabolical Principle," 11.

63"First Aid," 167. 
American letters and in providing a clear patch where fresh plants may grow. ${ }^{.964}$ Yet, as Lewis points out, they admit that the reason they possess this "warm feeling" for Surrealism and Communism "is because the movements which [Surrealism and Communism] represent are aimed at the destruction of a thoroughly rotten structure." Thus, the transition editors refuse to admit that their aesthetic crusade is linked to a larger political crusade to undermine Western culture. Lewis sets his sights on this apparent deception, bringing out its full implications: "It is the purpose of these gentlemen 'purely and simply' to 'amuse' themselves, but they have a 'warm sympathy' with anybody who aims at the destruction of Western Civilization (so they have a political interest in Western Civilization, and the problem of its political destruction). ${ }^{966}$

If the transition editors are guilty of concealing their political affiliations, however, Lewis is guilty of misrepresenting his own. Consistently, he denies the accusation that he has any connection to politics, reactionary or otherwise, but his explanation of his non-political stance reveals an underlying strategy for the generation of political confusion and controversy. In one section of "The Diabolical Principle," Lewis parodies the transition tone of levity when responding to their accusations of conservatism: "I of course never have had any intention whatever of 'Defending the West,' not even against itself-only of annoying Paul, Jolas, Sage, and Stein perhaps, a little, and so 'amusing' myself." ${ }^{967}$ Then, using satire to amplify what he feels to be the ridiculousness of the transition attack, he constructs an imagined dialogue between himself (L.) and a "personal canvasser" representing the editors of transition (P.A.J.),

${ }^{64}$ Ibid., 175.

${ }^{65}$ Ibid., 175.

${ }^{66}$ Lewis, "The Diabolical Principle," 17.

${ }^{67}$ Ibid., 15. 
who prods him regarding his alleged conservatism: ${ }^{68}$

P.A.J. 'So you are not a conservative you say!' (penetratingly): 'are you sure, Lewis?'

L. 'If you will tell me what I am supposed to wish to conserve I could perhaps answer you more easily.'

P.A.J. "You are "a status-quo-upholding britannic monarchist," in the pay of the late Duke of Northumberland?'

L. 'No. Not the Duke of Northumberland?'

P.A.J. 'Why do you attack Negroes in your books?'

L. 'Attack Negroes? I have never done that. I respect all the Negroes I have met for their unaffected high spirits.'

P.A.J. 'Then why have you written "Paleface"?'

L. 'I laugh at Whites for allowing you to persuade them that Negroes are their superiors in everything. I knew it would annoy you and the poor Whites wouldn't know what I was talking about. ${ }^{69}$

Although here Lewis is adopting the transition tone of mere "amusement," his last statement in this passage and his statement regarding his wish simply to annoy transition and amuse himself perhaps reveal more about his motives than he intended, as they imply that Lewis understood that he would be perceived as a reactionary by the likes of the transition editors. In other words, part of his strategy for fighting the kulturkampf involved provoking some of its most powerful and organized combatants.

\footnotetext{
${ }^{68}$ Ibid., 20.

${ }^{69}$ Ibid., 27.
} 
The particular work that the transition editors cite offers an example of the way that Lewis was able to provoke extreme reactions through subtle means. Paleface (1929) is a study of the relationship between whites and the non-white world, with a focus on what Lewis perceives as an attitude of submission on the part of whites towards AfricanAmerican and Indigenous cultures. Lewis does not valorize white culture, and even prophetically warns that a movement of pro-white reaction might arise in Europe, ${ }^{70}$ but he also refuses to valorize the racial "other," thus making it seem, at least to those with an ideological axe to grind, that his goal is, in part, to "attack Negroes." His message is that white people should find a way to respect the cultures of other races without committing racial and cultural suicide. This is a relatively subtle argument-too subtle to be injected directly into the intellectual war-zone of the kulturkampf. As far as the transition editors are concerned, one must be either an advocate of white submission and self-destruction or an outright bigot; Lewis was neither, and so his opinions on race had to be misrepresented as bigotry in order for them to make sense within the polemical categories of kulturkampf. Of course, Lewis knew how his arguments would be received: they would "annoy" the transition editors and confuse the "poor Whites." In the case of Paleface, subtlety of argument becomes a recipe for the incitement of literary violence. Paleface aside, if one examines the editorial notes in The Enemy that the transition editors were primarily reacting to in "First Aid to the Enemy," Lewis does appear to be "defending the west" in a particularly vociferous manner. For instance, in his discussion of the communism of the "Super-realists" (or Surrealists), he states that

\footnotetext{
${ }^{70}$ Regarding the state of racial relations in the world, Lewis remarks that "As far as I am concerned I would rather have things as they are than provoke in any way a reaction of intolerance. But there is no fear of that for the moment: and when the reaction comes, as it must, I hope that what I shall have had to say will serve to make its manifestations less ridiculous." Lewis, Paleface, 21.
} 
although he agrees with "much that the communist party advances, where it advocates radical change in our habits," he thinks that it has to be made compatible with Western traditions: "I believe that all this should be taken out of their hands-all that is not specifically communist and asiatic-and placed entirely in the hands of disinterested leaders of our race and traditions; and all that is alien to our traditions and race cut away from it, and handed back to Asia."71 Later, he laments that "adventurous" writers like James Joyce are forced to associate with the Dadaists and Surrealists of the transition group in order to have their works published and read, and proposes that the communist monopoly over the avant-garde should be fought through the development of a new radicalism of the West: "I am suggesting that we should take the intellectual initiative, in the anglo-saxon countries, and create a new 'radicalism,' if you like, and so steal the apocalyptic thunders of Moscow, and put 'revolution' to the uses of our whole Western community; using it to racial, instead of to class, ends, and no longer let it cut us up into innumerable 'classes,' sexes, and so forth, especially designed to tear each other to pieces." 72

Even in the bombastic excerpts of his editorial notes cited above, Lewis's argument is more subtle than it appears. The notion of racial unity having the power to transcend class-wars is a provocative one, but Lewis does not make a claim for the supremacy of the white race-only its difference. In the paragraph of his editorial notes before his statement regarding the potential value of racial unity, Lewis writes that he is offended by "the unseizable colour or tempo of the communist doctrine," which he feels

\footnotetext{
${ }^{71}$ Lewis, "Editorial Notes," xxiv-xxv.

${ }^{72}$ Ibid., xxvi.
} 
is incompatible with that of the West, but adds the following qualification: "And without at all claiming that my way of responding to life is a better way, it is at least exceedingly different. I flatter myself that in this I am in line with great quantities of people in the West irrespective of education or of gifts, of anything except the possession of a common racial inheritance, which sways us all alike in the most fundamental things." ${ }^{.73}$ What at first appears to be a claim for racial supremacy is more accurately a plea for racial equilibrium (if Lewis is using the term "race" in the biological sense at all). Such statements are far from being those of a die-hard reactionary or white supremacist, but it is at least understandable that they may have been interpreted as such by those lacking the patience to decipher the subtleties of Lewis's argument. Lewis knew that according to the binary logic of the kulturkampf, to attack the Left amounts to supporting the Right; an attack on communism will be interpreted as support for conservatism or fascism. He also knew that words like "tradition," "race," and "Western community" are "words of power" in the Hulmean sense, and thus tend to provoke emotional, and not intellectual, reactions.

Lewis's use of provocative and misleading statements-even if they are part of a subtler overarching argument-belongs to a rhetorical strategy which may be referred to as "shocking the shockers," to alter slightly a phrase used by Lewis's friend and disciple, Roy Campbell. ${ }^{74}$ Campbell become infamous in the 1930 s for his support of Franco during the Spanish Civil War and his relentless attacks on the British literary Left. He targeted both the Bloomsbury group, as in his poem The Georgiad (1931), and the

\footnotetext{
${ }^{73}$ Ibid., xxv.

${ }^{74}$ For a study of the relationship between Lewis and Campbell, see D.S.J. Parsons' "Roy Campbell and Wyndham Lewis," as well as Joseph Pearce's Bloomsbury and Beyond: The Friends and Enemies of Roy Campbell (2001).
} 
"Auden group" (comprised of W.H. Auden, Stephen Spender, Louis MacNeice, and Cecil Day Lewis), which he referred to with the composite moniker "MacSpaunday," as in his poem "Talking Bronco."75 In his first autobiography, Broken Record (1934), Campbell explains his use of "shock" rhetoric, and its function in the context of his alliance with Lewis:

'Shocking the bourgeois' is the silliest thing that we [as modern artists] do. I have always preferred to shock the shocker of the bourgeois, who is naturally and always a tame little figure, an inverted bourgeois himself: and there is nobody, even counting Lewis, who has promenaded more infuriating and insulting colours in front of this tame and cowardly gang of bourgeois-shockers, than I have. With Lewis there is more intelligence, wisdom and skill: I am only a banderillo in the cuadrilla of that great matador. ${ }^{76}$

The idea of "Shocking the shockers" that Campbell describes is the essential method of much conservative or reactionary satire: the conservative satirist mocks the New (which is, in the case of Campbell and Lewis, usually the literary Left) with the same amount of energy and venom that the partisan of the New expends in ridiculing the Old. The bullfighting metaphor that Campbell uses to describe his partnership with Lewis shows the calculation involved in their employment of this method. In a bullfight, the matador uses his skills to provoke, tempt, and deceive the bull, and is helped by the subordinates in his cuadrilla. The banderillero is the member of the cuadrilla who thrusts darts or banderillas into the neck of the bull. Campbell is thus describing himself as a person of

${ }^{75}$ Campbell, "Talking Bronco," 409.

${ }^{76}$ Campbell, Broken Record, 94. 
lower rank who is willing to engage directly in the literary violence that Lewis (the matador) instigates from a distance. Indeed, even at his most polemical, Lewis does not usually stoop to the defamatory accusations and insinuations that are trademarks of Campbell's poetry-although he may have approved from a distance.

The Lewis/Campbell strategy of "shocking the shockers" had a tendency to descend into the realm of adolescent teasing and bullying (although the same can be said of the strategies of the original "shockers" themselves-particularly those of the Dadaist/Surrealist transition group), and in the end it was a losing strategy if their goal was to generate publicity for themselves or win adherents. Many of their favourite targets-Gertrude Stein, the Bloomsbury group, the Dadaists and Surrealists, and even the Auden group-are now part of the pantheon of modern culture, while Lewis and Campbell were for a long time consistently marginalised, misrepresented, or simply ignored.

Nevertheless, it is important to recognize that Lewis's provocation of the literary Left served a higher purpose of which Campbell was perhaps ignorant, which was the creation of a creative rupture within the kulturkampf itself. Campbell may have sincerely believed in the Rightist ideals and romantic conceptions of battle and warfare that inspired his attacks on what he perceived as the effeminate Left, but Lewis was fully capable of turning his satirical eye on the Rightist intellectuals he sometimes appeared to be defending. For Lewis, the political Left and Right were both dupes in a larger scheme; his polemics were those of a partisan of the intellect, directed at the political world itself. In Lewis's view, the Left needed to be shocked, not because their cause was fundamentally unsound, but because they appeared to be descending into the kind of unquestioning ideological unity that, according to Schmitt, starkly separates a group of 
political friends from its enemies, and from which war may blossom. The transition writers, themselves a group of expert "bourgeois-shockers," needed to be shocked into questioning their own destructive cultural ambitions.

Lewis, especially in his Enemy phase, was intent on shattering the political preconceptions of his readers. One result of his refusal to take an easily-identifiable ideological stance is that his books are sometimes remarkably difficult to interpret on a first reading, largely because they are so replete with qualifications and seeming contradictions. There is little in Lewis's writing that would confirm the beliefs of those with strong ideological attachments-a fact that may explain why, according to Lewis, Joseph Goebbels (or, more likely, one of his minions) frowned upon the ideologically heterodox Hitler. ${ }^{77}$ Although some of Lewis's work does suffer from a genuine lack of organization, much of his argumentative slipperiness appears to have been intentional, with the intended effect on his readers being the creation of ideological confusion leading to a potential freeing of the intellect. By critiquing both the Old and the New without declaring a partisan stance, Lewis destabilizes the kulturkampf and creates a rupture within the semiotic reality that structures it. If this rupture extends into the semiotic reality of the reader, there exists the potential for the reader to undergo a conversion experience-a shift to a new semiotic reality. The type of conversion that Lewis hopes to inspire, however, is different from the type Hulme points towards with his critique of "words of power." Instead of being drawn into an archaic religious orthodoxy of unchanging values, the Lewisian convert will be flung outside the kulturkampf into a

\footnotetext{
${ }^{77} \mathrm{O}^{\prime}$ Keeffe, 330.
} 
non-partisan zone in which some semblance of intellectual freedom-from all rigid varieties of weltanschauung-is possible.

Lewis's idiosyncratic form of evangelism is a constant presence in his writings, even if it is not always explicit, and Lewis frequently seeks to develop a relationship with his readers, and play upon their sympathies. ${ }^{78}$ The intensity of the presence of his evangelism differs according to his intended audience and the genre in which he is writing. It is least present, perhaps, in his novels, where Lewis's authorial detachment from his subject matter leaves little room for the creation of a strong authorial persona. In his critical and polemical works, however, Lewis often creates a friendly authorial persona and seeks to ingratiate himself with the reader. Even at his most sophisticated and "highbrow," he never assumes the detached voice of the academic; instead, he riddles his prose with slang, invocations of popular culture, and casual asides. At the same time, he seeks to extend the limits of his readers' analytical abilities by subjecting

\footnotetext{
${ }^{78}$ Sue-Ellen Campbell devotes a chapter of The Enemy Opposite to "The Enemy's Audience," but does not offer a conclusive model of Lewis's relationship with his readers: "Lewis's problem here [in his relationship with his audience] has two aspects: on the one hand, he must try to keep his readers' interest and engage their sympathy; on the other hand, he must maintain his position as an enemy to everyone and everything. The virulence of his attacks on his opponents may widen the gap between them; the Enemy's forays are less likely to command the attention of his foes ... than to alienate them permanently... Similarly, his lack of restraint may offend those who might otherwise agree with him .... The Enemy's relations with his third possible audience suffer from similar difficulties. As Lewis makes clear in The Art of Being Ruled, he has nothing but contempt for those he sees as the unthinking masses; consequently, when he addresses the audience of the undecided, he is likely to alienate them as he does his declared opponents. As with the audience of allies, the Enemy's advertised isolation inhibits communication with the undecided: to gain support, as to recognize it, would be to destroy his role as a lone outlaw." Campbell, The Enemy Opposite, 34-35. Campbell's analysis places too much emphasis on the supposedly integral solitariness of Lewis's Enemy persona. It is true that the Enemy stance is incompatible with the formation of alliances in the usual sense, but Lewis's idea of a community of artist-intellectuals is one in which each member retains a large degree of autonomy. They are friends only in the sense that, as artist-intellectuals, they are all enemies of society at large; like Benda's clercs, they can all proclaim "My kingdom is not of this world." Benda, The Treason of the Intellectuals, 43. Lewis's goal is not to make friends with his readers, but to help make them enemies of society. He hopes to convert them, not to his particular way of thinking, but to the enemy perspective from which, according to him, all authentic artistic and intellectual creation and insight originates.
} 
their conventional conceptions of politics and culture to a process of diremption, thereby setting the stage for the creation of potentially new ideological combinations and constructions.

An implied author must have an implied reader, and in some cases, the type of reader that Lewis has in mind is clearly suggested. Even in The Art of Being Ruled, which is one of his most uncompromisingly "highbrow" works, Lewis makes it clear that he is not addressing an existing intellectual elite; his purpose is to gain converts. As I have already noted, Lewis's hope in The Art of Being Ruled is that an elite group may be formed from those who have read and understood his book. In his introduction to the book he offers the following explanation: "A book of this description is not written for an audience already there, prepared to receive it, and whose minds it will fit like a glove. There must be a good deal of stretching of the receptacle, it is to be expected." ${ }^{979}$ Lewis strives to create his own ideal reader through a "stretching of the receptacle," or the transformation of the reader's mind. As a result, The Art of Being Ruled is not structured around a single thesis that Lewis supports with clear evidence; rather, it is a chaotic collection of fragments of analysis that, when seen as building-blocks of new hybrid forms, suggest the possibility of a new way of perceiving modern culture.

In Time and Western Man, Lewis simply claims to be addressing the average reader. At the end of this monumental work, he signs off with an address that seems to belie the complexity of the material he has covered, writing, "I leave this critical essay in the hands of the reader, without further comment, in the belief that it will serve to throw into immediate relief the origins and implications of time-doctrine, in a form accessible

\footnotetext{
${ }^{79}$ Lewis, The Art of Being Ruled, 13.
} 
to the general educated person." ${ }^{" 80}$ This statement is misleading, for while a "general educated person" would be able to absorb with relative ease the first section of Time and Western Man, in which Lewis dissects the work of James Joyce, Ezra Pound, Gertrude Stein, and others, Lewis's argument becomes increasingly abstract and complex in the later sections of the book, and ultimately can only be fully understood by someone reasonably well-read in philosophy.

The rationale behind the authorial strategy in Time and Western Man is made clear in Men Without Art, a study of the relationship between literature and ideology. Lewis describes his method as involving beginning with familiar and easilycomprehended subjects and ideas and slowly progressing into more abstract realms: "By this means, ... namely that of progressing by easy stages from the particular to the general, it has been my object to lead on the general reader-the 'plain reader' perhaps is better-to an understanding of an absolute necessity of looking behind the work of art for something which is not evident to the casual eye, and which yet has to be dragged out into the light if we are to understand what any work of art is about. ${ }^{" 81}$ In many ways, this method contradicts the commonly held idea that modernist texts seek to alienate the reader. Lewis does not seek to shut out the masses (or at least the educated middle-class masses), but rather hopes to convert, by degrees, those few who possess the intellectual flexibility required to follow him to his ultimate conclusions and to become a fellow outsider.

It should be noted that the characteristics of Lewis's implied readers are not

${ }^{80}$ Lewis, Time and Western Man, 451.

${ }^{81}$ Lewis, Men Without Art, 11. 
always as easily discerned as in the critical works mentioned above, and such ambiguity has contributed to the critical confusion surrounding Lewis's authorial intentions. In many of his works, Lewis's implied reader is suggested by the cultural context of the work in question; when taken out of this context, Lewis's ideas are left open to misinterpretation. Hitler, for instance, was written not as a glorification of Hitler for those with existing Nazi sympathies, as might be assumed by those who have never read the book, but as a primer for a British public that had little knowledge of the Nazi movement. As Paul O'Keeffe notes in his biography of Lewis, Hitler was "the first booklength study in any language of Adolf Hitler and the phenomenon of National Socialism." ${ }^{" 22}$ Lewis presents himself not as a Nazi fellow-traveller, but rather as a political educator seeking to encourage the British public to take Nazism seriously as an important presence on the European political stage. The same can be said of his equally notorious works of the later 1930s, such as Left Wings Over Europe (1936) and Count Your Dead: They are Alive! (1937), both of which have been dismissed as pro-Nazi propaganda, but neither of which contains evidence of any consistent ideological allegiance to Nazism. For Lewis, an unthinking hatred of Germany, especially when accompanied by an unthinking dismissal of the threat of communism, did not constitute a serious appraisal of German or European politics, and could only result in war. The fact that Lewis was wrong regarding Hitler's intentions, and that the anti-German sentiment that Lewis perceived in British society in the 1930s was justified in retrospect, does not change the fact that Lewis had essentially peaceful evangelical intentions. Of course, many of Lewis's efforts to free his readers from the kulturkampf backfired severely, and

\footnotetext{
${ }^{82} \mathrm{O}^{\prime}$ Keeffe, 297.
} 
when war became inevitable, Lewis had nothing more to offer the British public and went into self-imposed exile in North America. In his later works dealing with the kulturkampf in England, such as the Rotting Hill (1951) stories, the evangelical urge of his 1920s and 30s works is present, but hidden beneath a veil of evasiveness; Lewis had learned that the kulturkampf itself may take revenge on those who attempt to disrupt its brutal binary structures. ${ }^{83}$

In some of his polemical works of the 1920s and 30s, Lewis goes so far as to satirize his own evangelical urge to educate and awaken. Such self-satire is particularly apparent in Count Your Dead: They are Alive!, a polemic structured as an imaginary dialogue, in which the Lewis-like Ned hacks away at the prejudices of the idiotic Launcelot Nidwit. Nowhere, however, does Lewis satirize his evangelism in a more explicit fashion than in the first section of his 1933 pamphlet The Old Gang and the New Gang, which was published as a supplement to Lewis's Doom of Youth (1932), an analysis of youth-politics that had a short-lived publication history, due in part to a libel suit brought about by Godfrey Winn and Alec Waugh. ${ }^{84}$ Although its literary merits are meagre, The Old Gang and the New Gang is valuable for the Lewis scholar because in caricaturing his own method, Lewis brings many of his evangelical strategies into sharp relief. In The Old Gang and the New Gang, Lewis lowers his analytical apparatus into what he considers to be the infantile realm of popular culture and, as if speaking to a child, he painstakingly shows, in the simplest of language, how the Old/New kulturkampf has been used in a calculated manner by those who hold the global reigns of power. This

\footnotetext{
${ }^{83}$ This is the theme of Lewis's 1937 novel, The Revenge for Love.

${ }^{84} \mathrm{O}$ 'Keeffe, 316-320.
} 
idea that the kulturkampf, although very real, has been appropriated, misrepresented, repackaged, and distributed to the public by a mysterious third party is present in The Art of Being Ruled and many of Lewis's subsequent political writings, but The Old Gang and the New Gang is significant for the close attention it pays to the cultural environment of the average Briton, and for its extreme authorial self-reflexiveness.

The first of the two sections of The Old Gang and the New Gang is devoted to critiquing the Old/New division as it presents itself in the cultural consciousness of the British "Mr. Everyman." As part of his critique, Lewis employs a narrative technique he bluntly refers to as "every-manning." ${ }^{\text {" Le }}$ Lewis slyly claims that his use of this technique is a reaction to the opinion of "experts in the reading capacity of the Public" that he is

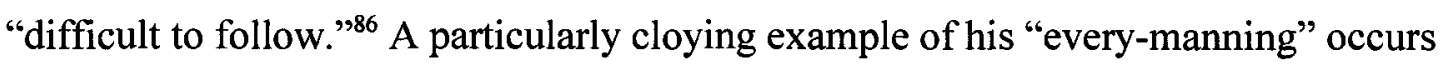
when Lewis explains the connection between the Jesuit technique of instilling religious values in young children and the emphasis placed on youth by the New Gang of modern politicians:

Now there's a funny old Bolshie with a funny old name (it makes us English laugh fit to split ourselves to hear it spoken), namely, that is, Trotsky. And Trotsky-though he's no longer the chief Bolshie-he might almost have been one of those Society of Jesus guys. . . Have you ever heard of Hitler? Funny name, too! Hitler-ha, ha, ha! It's as though he was going to hit you, isn't it? Well, old Hitler, he's got the same jolly old notion as old Trotsky. He's after the kids and brats as well, the old devil. ${ }^{87}$

\footnotetext{
${ }^{85}$ Lewis, The Old Gang and the New Gang, 33.

${ }^{86}$ Ibid., 18.

${ }^{87}$ Ibid., 16-17.
} 
Although such emulation of the alleged discourse of the "average man" is painfully condescending, it is part of a larger strategy-warped, in this case, through self-satire-that is essentially no different from that of The Art of Being Ruled or Men Without Art. His purpose is to analyse culture as it presents itself, and then to rearrange the fragments of his analysis into new structures that constitute closer approximations of political reality. With a tone of haughty derision that conflicts with his "every-manning," he explains:

There are a few little things I am about to say which, although they should not be over the head of a sucking-pig, may yet seem a bit stiff at first to a few of us. It is not because the actual material of the notions of which I shall have to treat is specially abstruse. As a matter of fact, the notions are anything but that, they are just the usual gossip-pars, and the old "kiss-stuff," and all that, of the Movies. Only what will be a bit startling will be the way I shall stick all these odds and ends together. ${ }^{88}$

As in Men Without Art, Lewis moves "by easy stages from the particular to the general," in this case using as his raw materials the signifiers of the everyday media-world. The gradual rearranging of these "odds and ends" reflects a potential transformation of the semiotic world of Mr. Everyman, for whom the political world exists only as a hazy collection of stereotyped images, half-understood slogans, and vaguely familiar names. The central idea that Lewis attempts to convey in his act of analytical diremption in The Old Gang and the New Gang is that the kulturkampf of the Old versus the New is far more wide-ranging and intricate than Mr. Everyman realizes, and that the media messages Mr. Everyman absorbs so light-heartedly are intimately connected to serious

${ }^{88}$ Ibid., 18. 
geopolitical realities: "The subject of this essay is a political gang-war that is going on all round us. But so little interest does the average citizen take in politics that he is quite ignorant of the meaning, and even of the very existence, of these factions.. ${ }^{899}$ Instead of seeing the kulturkampf as a pan-European or global phenomenon, Mr. Everyman's view of the kulturkampf is limited to what Lewis sees as the unreal world of the domestic politics of England. Mr. Everyman is constantly grumbling about the "Old Gang," or the stuffy, aged conservatives of British political life; he feels that the Old Gang is out of touch with the changing times, and that their inability to adapt to the modern world is the source of England's problems. The biases of Mr. Everyman are reinforced through the constant denigration of the Old Gang in the media, as Lewis suggests in the following imagined dialogue:

If . . you said to Mr. Everyman:

"Everyman! Have you ever heard of the 'Old Gang'?" To that Mr. Everyman would reply, with a broad responsive smile:

"The Old Gang? Yes, I've heard of the Old Gang all right! Who hasn't?" Assuming a more serious expression, he would subsequently add: "It's the Old Gang that's the ruin of this country!" So Mr. Everyman does know about the "Old Gang." For this there is an excellent reason. Every morning when Mr. Everyman opens his newspaper he reads about the doings of the "Old Gang"-or rather about their non-doing and non-caring. ${ }^{90}$

Certainly, if Lewis's research is reliable, the idea of the "Old Gang" was a

${ }^{89}$ Ibid., 9.

${ }^{90}$ Ibid., 9. 
dominant trope in the late 1920s and early 1930s. Lewis makes the claim that in his research, he "counted five hundred 'Old Gang' articles in three days." Although the results of Lewis's tabulation may be exaggerated, he does offer a number of examples of “Old Gang" headlines, ${ }^{92}$ and Doom of Youth contains an entire chapter of 39 "Exhibits" of reproductions of newspaper clippings featuring pro-Youth propaganda. ${ }^{93}$ The headlines that Lewis presents are meant to show a pattern of repetition of ideas, of "words of power" that function, like those that Hulme describes the Chinese Boxers using, as a means of exciting the public to the point of frenzy.

The ultimate purpose of this "pro-Youth propaganda," Lewis suggests, is the acceleration of the modern period of transition. Although England does not display its youth-fetish as openly as Italy, Germany, or Russia, it is essentially following the same route:

Much more than meets the eye of the unobservant (guys like you and me) does our nation go in for the "Youth"-racket. Beneath the walls of every fortress of prejudice or obsolete tradition in the land there are to-day "Crusaders" unfurling their pennants. (It is by no means a dull spectacle to watch some of these guys flinging their portly persons about and bawling "Youth" fit to burst.) We are getting our "Youth" vocabulary-there is a "Youth" mythology in the making. Our "Crusaders" are figures in their own pilgrim's progress-they are the "Frontfighters" of the Valley of Despond. And if they are pilgrims-well, it is all for progress that they plod on in the teeth of tradition. And theirs is the truest of

${ }^{91}$ Lewis, The Old Gang and the New Gang, 29.

${ }^{92}$ Ibid., 28-9.

${ }^{93}$ Ibid., 147-189. 
pilgrim's progresses, for PROGRESS with the biggest evolutionist $\mathrm{P}$ the printer has got in stock, that is their god. ${ }^{94}$

For these "frontfighters," Lewis suggests, "PROGRESS" is a Hulmean word of power, charged with meaning and replicated and distributed by the media. It is part of the "vocabulary" of Youth propaganda, which is in turn part of an emerging "mythology" or Sorelian myth, designed to motivate a segment of the population into radical action.

The complacent Mr. Everyman, of course, is not a "frontfighter." This category is presumably reserved for the avant-garde intellectuals of the transition variety.

Nevertheless, Mr. Everyman, despite his total lack of revolutionary energy, has been drafted into the ranks of the New Gang, if only through his conditioned mistrust of anything Old:

The "Old Gang," so far as they [Mr. and Mrs. Everyman] are concerned, exists in a satirical vacuum. There is no "New Gang"-in contrast to which the "Old Gang" have been nicknamed "old." If you got down to the unconscious levels (beneath the bright and sparkling everyday Everyman surface) you would find that the Everymans were in the habit hazily of considering themselves as the representatives of "the New." 95

The Old Gang function as stereotypes of the Old, or paper tigers within the Old/New division of the kulturkampf, serving only to make the New and its propagandistic slogans seem that much more appealing. They are scarecrows upon which the public can vent their frustrations, and in opposition to which they can define themselves.

\footnotetext{
${ }^{94}$ Ibid., 28.

${ }^{95}$ Ibid., 10.
} 
Essentially, the enmity that Mr. Everyman feels towards the Old Gang, and the pride and self-satisfaction he feels in being somewhat in tune with the changing times, are manufactured emotions leading him towards an ever-increasing state of infantilization and standardization. The more obsolete the Old appears to be, the more Mr. Everyman will attempt to mimic youth (leading to such phenomena as the dieting or "slimming" fad among women, as Lewis prophetically points out in Doom of Youth). ${ }^{96}$ Lewis notes that although Mr. Everyman has only the vaguest ideas of their motives, the representatives of Youth are precisely those who have, or who are poised to have, immense global political power, his examples being Trotsky, Hitler, Mussolini, and, in the British domestic realm, Sir Oswald Mosley. ${ }^{97}$ Without his knowledge or consent, Mr. Everyman is being radicalized, and drawn into a new political order that he would likely abhor, if he were conscious of its existence. Progressivism is the new conservatism, Lewis suggests; adherence to the weltanschauung of progress has become the default attitude of the British Mr. Everyman.

Mr. Everyman is both a facilitator of the kulturkampf and an object of manipulation. He thinks that he is insignificant and that he is removed from politics when, in fact, he is the very target of the political machinations that lie behind his cozy vision of the domestic kulturkampf:

it would be quite impossible to explain to Mr. Everyman the meaning of the warfare of the "Old Gang" and of the "New Gang" without going into this question of a definite well-thought-out policy, in perfect working order, and

\footnotetext{
${ }^{96}$ Lewis, Doom of Youth, 23.

${ }^{97}$ Lewis, The Old Gang and the New Gang, 16.
} 
everywhere at work, all of which is simply a gigantic gadget invented on behalf (or it would be better to say in consequence of) Mr. Everyman's own sweet little self. $^{98}$

For those who seek to control the new political order to their advantage, "Mr. Everyman is the big goose that lays the golden eggs."999 Lewis's analysis exposes, in Proudhonian fashion, a political contradiction: the mass man is simultaneously the least important and the most important player on the twentieth-century political stage.

In the second section of The Old Gang and the New Gang, in which Lewis drops his study of Mr. Everyman to focus on comparatively complex literary issues, he expands his discussion of the kulturkampf by suggesting that the Old Gang serves as a false front hiding a group of mysterious "others." Here, he begins to move "from the particular to the general," looking beyond the immediately perceivable aspects of the kulturkampf, and making new connections among the phenomena he has isolated. The reader who has followed him this far, presumably, will begin to feel a "stretching of the receptacle" leading to the possibility of conversion.

Lewis's analysis begins by focusing on the conventional critical attitudes towards World War I held by the youth who became its victims, such as the poet Siegfried Sassoon, but emphasizes the presence of a specific group of conspirators behind the scenes of the resulting kulturkampf. Those like Sassoon, Lewis notes, tended to demonize the military Old Gang and hold them responsible for the war. ${ }^{100}$ Lewis has no sympathy for the Old Gang that Sassoon attacked, but he feels that the blame for the war is

\footnotetext{
${ }^{98}$ Ibid., 12.

${ }^{99}$ Ibid., 13.

${ }^{100}$ Ibid., 45-6.
} 
misdirected. The Old Gang, who are accused of sacrificing the youth of England and creating a great missing generation of leaders, are in fact the pawns of a third party who are still at large:

What I have just said [regarding the myth of the cause of the generation gap between the Old and the Young] will I believe have tended to expose the fallacy inherent in blaming "The Old Men" or "The Old Gang" for all our various misfortunes. It is obvious that they should be arraigned: but there are others-others who are never mentioned! It is in short assuming that those venerable "leaders" possess much more power than is in fact the case. And further this superficial attack only serves to shield the real culprits, whoever they may be. Is it not equivalent to abusing the office-boy?-Lastly, Actions, not Words, are best in such a case. If these infirm Elders are the only obstacle, and the root of the trouble, they should have been turned out long ago-not been scolded and bullied while they were in the same breath confirmed in their office. ${ }^{101}$

The "others" that Lewis mentions are not described here, although in the roughly contemporaneous Hitler they are identified as Geldmenschen or "moneymen"-those financiers who stand to profit from the violent conflicts to which the intensification of the kulturkampf will inevitably lead. After dismantling the popular conception of the kulturkampf in the first section of The Old Gang and the New Gang, Lewis proceeds to plant the seed of a vast conspiracy theory in the mind of his readers, leaving it to them to draw their own conclusions from the fragmentary mass of observations he has accumulated.

\footnotetext{
${ }^{101}$ Ibid., 44.
} 
Despite his half-hearted attempt at "every-manning," and as the underlying complexity of his analysis suggests, the real target of Lewis's evangelicalism in The Old Gang and the New Gang is not Mr. Everyman, but rather once again the "general educated reader" and potential convert to outsider politics. Such a reader, presumably, would see Lewis's "every-manning" for what it is: a satirical device used to mock the masses and to foreground his evangelical intentions. Lewis gestures towards his ideal reader at the beginning of the second section:

Now for twenty odd pages I've been every-manning away for all I was worth and I think I will relax a little. I will not lose touch with the nursery. I shall continue to be "universal." But I will attempt to draw a few unimportant adults into the conference-at all events palpably wink at any minor breakages of the stringent box-office injunction-"NO ONE MENTALLY OVER SEVENTEEN

\section{ADMITTED!"’102}

Even earlier in The Old Gang and the New Gang, however, it is clear that Lewis's aim is not to liberate Mr. Everyman from his illusions. In fact, he perversely argues that the ignorance of the mass man should be encouraged and facilitated, and he only hopes that this process can be carried out in a relatively compassionate manner. In other words, it is probably best to let Mr. Everyman remain in a state of artificial reality, living on a primitive but comfortable cultural plane, as long as he is manipulated as a means to a peaceful end. Regarding the idea of keeping Mr. Everyman in a state of ignorance, Lewis asks:

But is not such a policy extremely arrogant and cruel, in fact? To such a

\footnotetext{
${ }^{102}$ Ibid., 33.
} 
question I should answer No. Quite the contrary, even: for most people are better pleased with a dependent, animal existence. The recumbent position is the most comfortable after all-it agrees best with the law of gravity. To "go upright" is all very well, but what for? If "happiness" is what we are talking about, then mankind has been jacked up too high, and must welcome this (even unceremonious) descent. ${ }^{103}$

He qualifies his recommendation, however, by saying that problems can occur "When the agents of this return to the primitive are themselves too primitive." ${ }^{904}$ Once again, Lewis's critique of the New is directed against its excesses, and its tendency towards the creation of violent conflict, rather than its fundamental principles. He is essentially repeating the argument of The Art of Being Ruled, in which he imagines a future society in which the masses have been pacified by technology and the media instead of being manipulated into social conflict by the Geldmensch. The artist-intellectual would then have some semblance of freedom, a peaceful segregation having been created between the "natures," or artist-intellectuals of a superior type, and the "puppets," or the rest of humanity. ${ }^{105}$

The polemics of Lewis's Enemy period put into action the critical model developed in The Lion and the Fox and The Art of Being Ruled. Working from an outsider's perspective, Lewis engages directly with the kulturkampf to dismantle and reconfigure its orthodoxies, invoke critical confusion, and create the potential for

\footnotetext{
${ }^{103}$ Ibid., 14-5.

${ }^{104}$ Ibid., 15.

${ }^{105}$ The terms natures and puppets are taken from Goethe. Lewis, The Art of Being Ruled, 125. The idea of a segregation between the two appears in The Art of Being Ruled, pages 367-368.
} 
conversion among his middle-class readers. More specifically, he identifies, absorbs, and dirempts the Old/New division in its various manifestations, and attempts to construct a "political equilibrium" by strategically supporting reactionary ideas that contradict, and thus bring into balance, the dominant revolutionary orthodoxy. This diremptive act contributes to the creation of critical confusion, leaving his subtle arguments in favour of ideological balance open to wild misinterpretation. Such confusion, however, feeds into his evangelical strategy-potentially creating a rupture in the semiotic reality of his readers, which is the precondition for any conversion experience.

These writings are a product of something far more complex than anti-modern reaction. If Lewis was engaging in a "Defence of the West," the vision of the West that he supported was one rooted in the Western creative impulse, and not in any sort of ancient and rigid value-system; a true reactionary or staunch traditionalist could only find Lewis's polemics perplexing and ultimately unsatisfying. It is fitting, then, that what is perhaps the most accurate description of Lewis's Enemy stance comes from an editorial entitled "An Enemy Worth Having" that appeared in a 1927 issue of New York's longrunning left-liberal periodical The Nation. The anonymous writer praises Lewis for investigating ideas shunned by the orthodox left, and for an intellectual adventurousness that is uncharacteristic of conservatism in its usual manifestations:

Mr. Lewis is a radical in the literal sense of the word-he is looking for the roots of things and as he digs down after them the dirt flies. But he accepts, on the other hand, very few of the dogmas of current radicalism and he is no part of the dominant Spirit of the Age. He sees no reason why the opponents of certain "radical" tendencies should confine themselves to dull platitudes nor why all the 
daring and brilliance should be on one side. Perhaps, indeed, he is really that very rare and hence very valuable thing, an intelligent conservative .... Even those who believe most firmly in all that he doubts will do well to read him, for he is an enemy worth having in a day when radicals seldom have a chance to match themselves against any except second-rate minds. ${ }^{106}$

It might be added, however, that conservatives could also consider him "an enemy worth having," given that he claimed to belong to no party. Lewis, in his Enemy phase, was a solitary antagonist and a self-made martyr, publicly playing the role of enemy-of-all, and suffering the consequences, so that others might be saved.

106"An Enemy Worth Having," 535. 


\section{Chapter Three}

Castor Oil for Conservatives?: Wyndham Lewis and Fascism

During the 1930s-as his Enemy phase gradually came to a close-Wyndham Lewis discerned the development of what he saw as "a repressive "left-wing' orthodoxy" in British culture and retaliated with a series of provocative polemical works: Hitler (1931), Left Wings Over Europe (1936) and Count Your Dead: They Are Alive! (1937). ${ }^{1}$ In these writings, all of which focus on the impact of fascism on the European political landscape, Lewis significantly modifies his vision of the kulturkampf. Lewis recognized that within the collective British consciousness, the battle between the New and the Old had become fused with the related battle between the political Left and the Right. In response, he subjects the Left/Right conflict to a process of diremption and isolates and examines fascist ideology in particular, recasting fascism as a fusion of the Old and New and as a possible form of resistance against a new internationalism or "world-brotherhood at Geneva." At the same time, Lewis attempts to infuse the kulturkampf with a new political realism and make its complexities understandable to the British public.

Lewis's political polemics of the 1930s have been the subject of much critical debate and little critical analysis; those who seek to vilify Lewis have presented them as evidence of Lewis's support for fascism, while those who seek to exonerate Lewis from such charges tend to dismiss them as misguided anti-war tracts or products of a temporary lapse of reason. ${ }^{3}$ It is my opinion that both of these critical positions are

\footnotetext{
'Lewis, "Freedom that Destroys Itself," 794.

${ }^{2}$ Lewis, Left Wings Over Europe, 144.

${ }^{3}$ Victor M. Cassidy, in a 1993 article in The New Criterion, blames Lewis's support of fascism on his anti-war stance, remarking that "In his eagerness to prevent a second world war, Lewis misread fascist intentions. There can be no doubt of this. But he supported Hitler and Mussolini far more enthusiastically and far, far longer than common sense or decency should have allowed. Lewis was
} 
misleading, and that these works must be read as logical extensions of the method of criticism Lewis developed in the late 1920s and early 1930s (an assertion bolstered by the fact that Hitler itself is roughly contemporaneous with such works as Doom of Youth and Men Without Art). While Hitler, Left Wings Over Europe, and Count Your Dead may certainly be read as fascist apologetics (of a highly qualified kind), I argue that they may be more accurately described as evangelical tracts designed to educate and enlighten the British public; specifically, they constitute a contribution to an effort on the part of a distinct group of disaffected British and American Rightists to reinvigorate conservatism by forcing it to reexamine its own fundamental principles in light of the "castor oil" being administered to European politics by fascism-castor oil being for Lewis, a metaphor for truth or objectivity. ${ }^{4}$ To describe this group of thinkers whom Lewis sought to aid, I will use the term "revolutionary conservatism"-a term that Jay P. Corrin has brought attention to, and that was coined by Seward Collins, a prominent American conservative thinker of the $1930 \mathrm{~s}^{5}$ With roots in late nineteenth- and early twentiethcentury Catholic thought, revolutionary conservatism became increasingly influential during the 1930s, functioning as the guiding ideology of two important conservative

not an evil man, but an arrogant naif who blundered into politics and made a complete fool of himself." Cassidy, 35. Philip Head also focuses on Lewis's 1930s anti-war motives in "Counting Your Dead." Andrzej Gasiorek provides an even-handed overview of Lewis's politics, including his 1930s polemics, in Wyndham Lewis and Modernism. Gasiorek, 77-99. I agree, in particular, with Gąsiorek's statement that "What becomes increasingly clear in texts like Left Wings Over Europe and Count Your Dead: They Are Alive! is that, despite his avowed hostility to abstract political theories, it was Lewis who conceptualized the political scene in highly abstract language, ultimately reducing it to a straight conflict between two overarching, and radically opposed, political principles: centralization versus decentralization. For Lewis, this was the deeper and more momentous conflict that lay half-hidden beneath contemporary political rhetorics." Gąsiorek, 8687. I would add that beneath the centralization versus decentralization conflict lurks a more fundamental conflict: the Old/New division of the kulturkampf. ${ }^{4}$ Lewis uses the "castor oil" metaphor in Count Your Dead. Specific instances of its use are cited later in this chapter.

${ }^{5}$ Corrin, G.K. Chesterton and Hilaire Belloc: The Battle Against Modernity, 163. 
journals, The English Review under the editorship of Douglas Jerrold (1931-1936) and The American Review under the editorship of Collins (1933-1937). For Lewis, revolutionary conservatism possessed the potential to incorporate the emerging realities of the age of the dictators into the Old/New or Left/Right kulturkampf within British society.

Hitler, Left Wings Over Europe, and Count Your Dead may be read as a political trilogy in terms of their aim and content. Hitler offers British readers insight into what was at the time a poorly understood political movement. Lewis studies the central characteristics of the Nazi movement-its racial theories, proselytizing methods, economic program, and führer-centered hierarchy-with a sympathetic eye, his aim being to make Nazism comprehensible (if not acceptable) to the average Briton. To accomplish this educational goal, Lewis subjects Nazism to a process of diremption, offering as prospective political models for England those aspects of Nazism that are potentially compatible with British politics, and dismissing those (such as anti-Semitism) that he sees as applicable only within the German cultural context. Left Wings Over Europe is a long polemic in which Lewis seeks to defuse the brewing conflict between England and the fascist nations by bringing attention to what he sees as the aforementioned left-wing bias in the British media and national government. While it has often been rightly characterized as an anti-war tract by those sympathetic to Lewis, it may also be understood as yet another component of Lewis's effort to engage with the modern kulturkampf and help bring it into a state of political equilibrium. By pleading the case for peace with Germany-which he considered to be the weakest, most marginalized player in the kulturkampf-Lewis hoped to level the playing field in the arena of public 
political debate. Count Your Dead, despite its poor reputation, is perhaps Lewis's most complex polemical work of the 1930s. In place of lengthy analysis (such as that found in Left Wings Over Europe) Lewis stages a fictional dialogue between two essentially conservative characters: Launcelot Nidwit, who represents the antiquated Toryism of the mainstream Conservative party, and Ned, who represents a revolutionary conservatism informed by fascist ideology. Launcelot clings to what Ned refers to as the "fake antique" conservatism of Stanley Baldwin and the Conservative party, the popular symbols of which are the British icon John Bull and cartoonist David Low's mustachioed moron, Colonel Blimp. ${ }^{6}$ Count Your Dead represents both Ned's tribute to Launcelot, whom he metaphorically euthanizes through the administration of political castor oil, and an obituary notice for Tory complacency. Launcelot's eventual conversion to Ned's point of view marks his liberation from an outdated and illusory kulturkampf and his (ultimately fatal) entrance into political "reality."

All of these works are firmly rooted within the political context of 1930 s England. ${ }^{7}$ From 1931 to 1940 , British political life was overshadowed by the presence of the conservative-dominated coalition or national government, led first by Ramsay MacDonald (1931-35), then Stanley Baldwin (1935-1937), and finally Neville Chamberlain (1937-1940). Hitler was published at the beginning of this era, while Left Wings Over Europe and Count Your Dead are both products of the period under the Baldwin leadership, which is often characterized as a time of conservative lethargy and political indecision. All were written in response to specific international crises that

${ }^{6}$ Lewis, Count Your Dead, 6.

${ }^{7}$ For a general discussion of these works in relation to British political life, see Bridson, The Filibuster, 95-119; 140-65; 166-187. 
occurred during this period: Hitler appeared in the aftermath of the 1929 stock market crash and the significant gains made by the Nazis in the 1930 Reichstag elections, Left Wings Over Europe addresses the British reaction to the 1935-36 Italian invasion of Abyssinia (Ethiopia), and Count Your Dead addresses the British reaction to the events of the first year of the Spanish Civil War. These crises reinforced a split in British political life between the Left and the Right that was becoming increasingly evident during the course of the 1930s; the kulturkampf between the Old and the New, and the Right and the Left, was rapidly transforming into a battle between the more specific political entities of fascism and communism. In 1936, with the beginning of the Spanish Civil War, British intellectuals were forced to align themselves with one of the two entities fighting for power in Spain: the Nationalists (who were assisted by Germany and Italy) or the Republicans (who were assisted by the Soviet Union and the International Brigades). Throughout this period, Lewis repeatedly claimed that both the British literary world and the mainstream media were almost unanimously siding with the Left, which he perceived to be unfair. His response to this situation was, I propose, meant to be less a contribution to the fascist cause in Europe than a carefully considered intervention in the British domestic kulturkampf-a battle represented by the ideological divisions between such periodicals as The New Statesman and Nation and The English Review (or, for that matter, between Victor Gollancz's famous Left Book Club and its smaller nemesis, the Right Book Club). ${ }^{8}$ In this respect, Lewis's defence of fascism and Nazism was

\footnotetext{
${ }^{8} \mathrm{I}$ do not consider the Left and Right book clubs in this study, but their significance in the British culture of the 1930s is amply demonstrated in E.H.H. Green's Ideologies of Conservatism: Conservative Political Ideas in the Twentieth Century, in the chapter "The Battle of the Books: Book Clubs and Conservatism in the 1930s." Green, Ideologies of Conservatism, 135-156. Paul Edwards has noted the existence of a promotional flyer for Count Your Dead that announces Lewis's intention to start his own "'Rightwing Bookclub"'-one that will provide an opposition to
} 
fundamentally different from Ezra Pound's advocacy of Italian fascism; Lewis, firmly situated in the cultural environment of pre-war England, wrote for a British audience, while Pound, through his wartime radio broadcasts from Mussolini's Rome, spoke from the heart of the enemy's lair to Europe, North America, and the world.

In situating Lewis's defence of fascism as an intervention in the British kulturkampf, and his praise of the Nazi economic model as a contribution to British revolutionary conservative ideology, I do not mean to ignore or excuse the irresponsibility of his rhetoric. Although Lewis never made any explicitly anti-Semitic utterances, and eventually came to the defence of European Jews with the unfortunately titled The Jews-Are They Human? (1939) (the title being a parody of Gustaaf Renier's 1931 book, The English-Are They Human?), he nevertheless made use of rhetorical tropes that were common in the anti-Semitic literature of the time-period. Whether or not his intent was malicious is another question entirely-one which is in some ways beyond the scope of this study, which deals primarily with Lewis's authorial persona, or the image of himself that he consciously created.

Another reason why I hesitate to accuse Lewis of anti-Semitism is because the charge is a serious one, and requires support consisting of careful and exhaustive analysis that could only be contained in a separate study. Unmethodical attempts to determine the extent of Lewis's personal responsibility for the generation of anti-Semitism and Nazi sympathy in England can easily result in unfair accusations based on unfounded generalizations. Leon Surette, for example, in Pound in Purgatory: From Economic

both the Left Book Club and the Right Book Club. Edwards, Wyndham Lewis: Painter and Writer, 389. Presumably, Lewis's book club would have promoted the revolutionary Right, rather than the traditional Right. 
Radicalism to Anti-Semitism, suggests that Lewis's "brutal cynicism" regarding the question of race in Hitler is "perhaps more culpable than [Ezra] Pound's misguided conviction" (presumably regarding the motives of Mussolini) in Jefferson and/or Mussolini (1933). ${ }^{9}$ He adds that "Lewis's Hitler is not only more objectionable from either a liberal or a Marxist perspective than Pound's Jefferson and/or Mussolini but it is also far less naive and sophomoric. Lewis's analysis is better informed and more cogent than Pound's, and in fact reflects the mainstream British reading of political events of the day. Pound's analysis is eccentric and eclectic-an indigestible mixture of Social Credit, fascism, Marxism, and Jeffersonian democracy."10 It is not clear why Pound's attitude of hero-worship towards Mussolini is deemed merely naive, while Lewis's attitude of cautious approval (tempered by a number of important reservations) towards Hitler is particularly damning, or why Lewis should be singled out for censure if he was simply articulating "the mainstream British reading of political events of the day." Presumably, this is because Lewis, according to Surette, "believes in a Jewish conspiracy" while Pound (at that time) did not-an accusation based on Surette's detection of coded references to Jews in Hitler. "Is it not possible that Lewis's understanding of Hitler was, like Pound's understanding of Mussolini, blurred either by naïveté or by his own adherence to "an indigestible mixture of Social Credit, fascism, Marxism, and Jeffersonian democracy"? Pound, as Surette shows in great detail in his book, became a blatant anti-Semite in the late 1930s and continued to make explicitly anti-Semitic comments well after World War II, when the extent of Hitler's attempted Final Solution

\footnotetext{
${ }^{9}$ Surette, Pound in Purgatory, 95.

${ }^{10}$ Ibid., 95.

${ }^{11}$ Ibid., 95.
} 
became public knowledge. Lewis, in contrast, admitted his previous naïveté and spoke out publicly in 1939 against both anti-Semitism and Nazism (in The Jews-Are They Human? and The Hitler Cult, respectively), which does not excuse his irresponsible rhetoric but does, perhaps, show that Lewis's fascist posturing was largely superficial. By indulging in an offhand comparison, Surette suggests Lewis should be remembered only as a brutally cynical anti-Semite.

Lewis's sympathetic appraisal of Nazi economics (which incorporates a number of tropes commonly associated with anti-Semitism) must be seen both within the context of anti-Semitic conspiracy theory and a range of similar discourses regarding the nature and purpose of modern economics. Nazi economics had their roots in anti-Semitism (and particularly in the German reaction to the notorious forgery, The Protocols of the Elders of Zion, which purports to be a document outlining a plan for Jewish world-domination), but there existed other critiques of credit-based economies in which anti-Semitism played no part, or in which it was not integral. The Catholic church, for example, fostered the development of anti-usury economic theory in the modern age through the papal encyclicals Vix Pervenit (1745), Rerum Novarum (1891), and Quadragesimo Anno (1931). It was this tradition that inspired G.K. Chesterton and Hilaire Belloc's economic philosophy of distributism. Social Credit theory also had a widespread influence in the 1920s and 30s, and its aforementioned originator, Major C.H. Douglas, published extensively in A.R. Orage's The New Age-a periodical with which Lewis and many other modernist writers were affiliated. Although some advocates of Social Credit (including Douglas) held anti-Semitic opinions, there is no necessary connection between anti- 
Semitism and Social Credit, as there is between anti-Semitism and Nazism (which Lewis arguably failed to recognize).

My own position regarding the matter is that since Lewis displayed no obvious personal hatred towards Jewish people in his writings or his letters, it is difficult to draw a direct link between his economic ideas and anti-Semitism. In the 1930s he certainly entered into a dangerous ideological terrain in which anti-Semitism tended to flourish, but judging from what Lewis actually wrote, the conspiratorial financiers that he denounced were of no specific race or religion. He may have allowed his authorial persona to mimic some of the anti-Semitic tropes he borrowed from Nazism, but he also sought to disavow any ideological allegiance with anti-Semitism. If he is clearly guilty of anything, it is of treating politics too lightly, and handling living, potentially explosive ideologies as mere idea-systems that could be dirempted and ironized. In this respect, Lewis was guilty of the type of artistic arrogance that similarly inspired W.H. Auden, Stephen Spender, and Cecil Day Lewis to employ, until the later 1930s, the violent rhetoric of the other major totalitarian ideology of the era. Lewis was perhaps willfully ignorant of the potential consequences of his appropriation of anti-Semitic rhetoric, but there is no evidence that his complicity in the spread of anti-Semitic ideology was on the level of that of a William Joyce (the British fascist who became the infamous Nazi propagandist "Lord Haw-Haw"), or even an Ezra Pound.

For the purposes of this study, Hitler, Left Wings Over Europe, and Count Your Dead are important because Lewis's study of Nazism solidified some of the political and economic ideas he had been absorbing and half-articulating in his earlier work-ideas that 
became major elements in his later intervention in the kulturkampf through his support of revolutionary conservatism in Count Your Dead. ${ }^{12}$

In Hitler, Lewis presents himself as "an exponent-not as critic nor yet as advocate-of German Nationalsocialism, or Hitlerism." ${ }^{\text {13 }}$ Lewis's imprudent stance in relation to Nazism is easy to condemn in retrospect, but at the time of the publication of Hitler, the Nazis were still struggling for power in Germany, Benito Mussolini had not yet met Hitler, and Sir Oswald Mosley (the future leader of the British Union of Fascists) was still a former Labour MP in the process of converting to fascism. The terrifying political landscape of the later 1930s had not yet taken shape, and Nazism did not occupy a prominent position in the British national consciousness. Furthermore, the Nazis, in the stage of development they were in when Lewis first witnessed their activities, ${ }^{14}$ were attempting to achieve power legally; in Hitler Lewis stresses that "Nur legal!-only by legal means-is the watchword of the Nazis today." In Lewis's eyes, the Nazi revolution was proceeding in a manner "fair, square and above-board to the letter,"16 a principle that he appears to have believed would have been central to their foreign policy, in the case of the establishment of a Nazi dictatorship. Thus, Hitler was potentially a great lawbringer

\footnotetext{
${ }^{12}$ Lewis's description of the European socio-economic situation in The Art of Being Ruled, for example, would have fit nicely into the economic analysis in Hitler: "Giant Trusts and Cartels everywhere, at the present time, as they coalesce, approach the economic pattern of the socialist state. Whether the trust-king is a highly salaried servant (as Lenin said he should be, if proved to be the most efficient organizer), or a capitalist magnate (when these chiefs become fewer and fewer, as they do every day), does not particularly matter. The enemy of unification today is everywhere the 'small man'." Lewis, The Art of Being Ruled, 103. The difference, however, is that in The Art of Being Ruled, Lewis positions himself against the small man, whereas in Hitler, the small man is valorized.

${ }^{13}$ Lewis, Hitler, 4.

${ }^{14}$ Lewis visited Germany in November 1930. O'Keeffe, 296.

${ }^{13}$ Lewis, Hitler, 55.

${ }^{16}$ Ibid., 65.
} 
and advocate of political transparency-essentially “a Man of Peace." ${ }^{17}$ Lewis's evaluation of Hitler constituted, of course, a gross misinterpretation of Hitler's character and goals, but such a misinterpretation is arguably understandable given the manner in which the Nazis were presenting themselves at the time.

In Hitler, the central reason why Lewis determines the Nazis to be a political force worthy of serious consideration is their potential as a model for the elimination of the "many "class-wars"" erupting in European society. ${ }^{18}$ In using the term "class-wars," Lewis is referring to conflicts or "civil wars" between any variety of classifications of people, such as the wars identified in The Art of Being Ruled (which he quotes from extensively), and which I have defined as varieties of kulturkampfen that belong to a larger kulturkampf. ${ }^{19}$ Invoking the idea of the larger kulturkampf between the Old and the New, he acknowledges both the necessity of and the danger posed by these wars:

Has there ever been a human society free of great abuses deserving upheavals? And the Industrial Age did shake our society like an earthquake; it loosened its structure, and, as it imposed upon everybody new conditions of life, it set up a natural conflict between those with imagination and spare energy, who wanted to go quick, and those who resented the New, and wanted to go slow, or not at all. So it is not any too easy to discuss, without misunderstanding, the policy of these Civil Wars or 'Class-wars,' which honeycomb our Western democratic communities today. ${ }^{20}$

\footnotetext{
${ }^{17}$ Ibid., 44.

${ }^{186}$ "Many "Class-Wars"" is the title of a chapter beginning on page 69 of Hitler.

${ }^{19}$ Lewis, Hitler, 78-82.

${ }^{20}$ Ibid., 74.
} 
It is apparent in this quotation, and in many of Lewis's other works, that Lewis sees the $\mathrm{Old} / \mathrm{New}$ conflict as something necessary to the development of society-as long as this conflict does not escalate to apocalyptic proportions. What Lewis dreaded was that this conflict, along with the many sub-conflicts it has spawned, might, if allowed to intensify, result in a "Civil Armageddon":

In their Programm the Nationalsocialists catalogue our Chaos-it is 'a picture of a battle of all against all.' The Revelation of St. John the Divine does not provide a more chaotic scene, of dream-like universal conflict, than what we now witness all about us, everywhere in the world. This carefully-planned system of conflicts-of 'class-wars'-is plotted like the checkboard patches of a garden, designed to represent a wilderness of misspent human ingenuity.

... It does not require phenomenal foresight to discern that at any moment this universal Unrest could be made to swell up suddenly into a world-storm of unparalleled proportions-a 'War-to-end-Class-War' as it were. And the more 'Classes' that are contrived, the more likelihood of some ultimate Civil Armageddon to abolish them. ${ }^{21}$

Lewis's use of apocalyptic imagery in his reference to the Book of Revelation in this passage is significant, not just for its association with the idea of the end of the world, but more specifically in its connection to the social theory of Georges Sorel. As The Art of Being Ruled amply demonstrates, Lewis saw Sorel as a major influence on twentiethcentury politics, particularly in his advocacy of the use of apocalyptic myths to inspire unity and the capacity for violence in political movements. It is ironic that although

${ }^{21}$ Ibid., 69. 
Sorel's ideas are closely tied to fascist ideology, Lewis sees Hitler as the antidote to Sorelian class-warfare.

What the Nazis are poised to provide, as Lewis sees it, is a kind of stability and order that might bring class wars to an end without fueling a larger "War-to-end-ClassWar." What is also apparent in this passage, and what Lewis appears to have derived from Nazism and some of the radical economic theoreticians of the time, is the idea-not clearly apparent in The Art of Being Ruled-that these various kulturkampfen or "classwars" are being fueled by a mysterious third party or group of plotters. ${ }^{22}$ Lewis later identifies this third party or "third class" as the team of "the Geldmensch [money-men] and the Agitator." ${ }^{223}$ It is they who seek to create the "Klassenmensch-or "Class-person," who is a "mechanical Infant-Robot" or "standardized Peter Pan," and "a phonograph for the convenient parrot-cries of the hour."24 War of any kind generates debt; thus, the Agitators create conflict and the Geldmensch move in to supply loan-capital. Lewis describes the situation as follows, at one point using the term "shekels" instead of "money," thus displaying an ominous but ultimately undeveloped rhetorical flirtation with anti-Semitism: "When two nations fall out, the armament-king and chemical-king rake in the shekels. When two men fall out, the lawyer coins money. When two Classes fall out, it is the same thing. Power, or wealth, passes from both to some third Class."25 Like a perversion of the Hegelian idea of synthesis, the "third class," which Lewis never explicitly identifies with Jewish people, feeds off of the tension created by the thesisantithesis tension inherent in any kulturkampf.

\footnotetext{
${ }^{22}$ Ibid., 162.

${ }^{23}$ Ibid., 75.

${ }^{24}$ Ibid., 89.

${ }^{25}$ Ibid., 75.
} 
As I have already noted, Lewis, at least in Hitler, does not consider the kulturkampf to be entirely destructive. It is only its strategic intensification by third parties that is problematic:

This ferment [in modern culture] did good till it got into the hands of the crook: he always seizes upon a weak inflamed spot in a society to do some mischief and extract some loot. The Geldmensch and his satellite the Agitator were soon on the job. They organized these masses of people in disequilibrium-displaced and uprooted as a consequence of the Industrial Revolution. They organized them into 'Classes.' There was nothing they did not fake up into a 'Class.' And they manufactured and stuck upon each 'Class' they had isolated and organized, a label, or a ticket: they might have been cattle. ${ }^{26}$

Once again, Lewis presents himself not as a reactionary but as a revolutionary disturbed by the way revolutionary ideas have been co-opted and vulgarized. Lewis uses the term "disequilibrium" to describe the modern cultural landscape in this context-thus echoing his statements in favour of "political equilibrium" in The Art of Being Ruled.

Lewis makes the case that the aim of the Nazis is to eliminate the Geldmensch and the Agitator, and bring Europe (or at least Germany) into a state of equilibrium once again. As Lewis sees the situation, the Nazis mean to accomplish this in two ways: first, they plan to replace the various "classes" with a single, overarching emphasis on race, and second, they plan to institute a new economic system that would make it impossible for the Geldmensch and Agitator to continue their exploitation.

\footnotetext{
${ }^{26}$ Ibid., 74-5.
} 
Lewis sees the first of these two goals as problematic, but potentially beneficial. He remarks, "What I think it is safe to affirm is that 'Race,' used as a propagandist engine, must tend to simplify and concentrate. It promises political unity, at all events."27 However, he adds, "It must however be absolutely understood that there is no question of the Anglo-saxon ever emulating this 'racialism' of the Germans." 28 Although he does not think that such extreme racialism would ever succeed in England, he does later imply that a looser, more moderate emphasis on race might be acceptable. He cautiously suggests that "the Anglo-saxon should not be too complacent perhaps about the entire absence in himself of any feeling that could be described as 'racial.' I am persuaded that the opposite-the diffusionist, racial-olla-podrida camp-is equally if not more easy to ridicule." 29 At the very least, a moderate racialism would present an alternative, for "the English or American Undergraduate," to "unadulterated Toryism" and "unadulterated Communism," 30 and would also occupy a position somewhere between the "Aryan" supremacism of the Nazis and the "diffusionist" ideal of unrestrained racial mixing. This is a questionable political position in itself, and does not sound moderate today, but it is nevertheless evident that, at least on the surface, Lewis's proposed racialism was not rooted in irrational racial prejudice or xenophobia. In fact, Lewis sees racialism as a possible means of bridging the cultural divides between European nations. As he speculates in the chapter "Aryan' Hegemony and a Germanic Volapuk?,"a racialist movement centered in Germany, and a German-inspired universal language like Johann Martin Schleyer's "Volapük," might be able to help break down barriers of nation and

\footnotetext{
${ }^{27}$ Ibid., 85 .

${ }^{28}$ Ibid., 85 .

${ }^{29}$ Ibid., 108-09.

${ }^{30}$ Ibid., 109-10.
} 
language. ${ }^{31}$ Such a situation would forge a new European unity, and help prevent the occurrence of future wars, for as Lewis notes (with italics for impact), "The Great War was, in fact, a Great Civil War. ${ }^{932}$

Although he is skeptical regarding the ultimate value of Nazi racialism, Lewis appears to take a more serious interest in the Nazi economic program. As he points out, the Nazis make a sharp distinction between "productive capital" and "loan-capital," with the latter being reprehensible because it creates an economy based on debt. ${ }^{33}$ Thus, one of the great aims of the Nazi movement, and one of the reasons for its electoral success, is its policy of "debt-repudiation," and in particular the planned repudiation of the debt created by the Treaty of Versailles. Lewis draws attention to the fanaticism of the Nazis in this regard, stating, "As regards the financial side of the Hitlerist doctrine, there is no question at all that a violent attack upon the whole Technique of Credit is contemplated," and he supports this assertion with relevant quotations from Das Programm der N.S.D.A.P. by Gottfried Feder (the Nazi economist, here unnamed, but who resurfaces later by name in Count Your Dead). ${ }^{34}$

The idea of the dangers of an unchecked debt-economy haunted Lewis throughout the 1930s, but even as early as Hitler, Lewis was aware of other sources for this type of anti-credit economic theory besides fascism; in Hitler, as a means of making Nazi economics palatable to the British reader, Lewis introduces the more recognizable figure of the Anglo-Saxon "credit-crank." ${ }^{35}$ The credit-crank is the enemy of debt, and seeks to

\footnotetext{
${ }^{31}$ Ibid., 140-43.

${ }^{32}$ Ibid., 142.

${ }^{33}$ Ibid., 147.

${ }^{34}$ Ibid., 174-75. Feder is mentioned on pages 16 and 286 of Count Your Dead.

${ }^{35}$ Lewis, Hitler, 160.
} 
replace an economy based on artificial shortages with one based on the fair distribution of goods. ${ }^{36}$ Lewis offers a highly satirical portrait of the credit-crank, but nevertheless suggests that his economic message should be heard. Lewis declines to name specific credit cranks, aside from Major C.H. Douglas, Sir Oswald Mosley, and some obscure Australian politicians, but does note that T.S. Eliot expressed some interest in creditcrankery within the pages of The Criterion.$^{37} \mathrm{He}$ admits that although he is ignorant regarding economics, "I have often thought that were I to address myself to the mastering of this dreary subject, and if I became proficient in the so-called Science of Economics, that I should be nothing more or less than a 'Credit-crank'!"38 Lewis did in fact become something of a credit-crank after Hitler, which is an aspect of his thought that has often been overlooked. ${ }^{39}$ Moreover, it was not a passing interest; as late as Rotting Hill (1951), Lewis showed enthusiasm for this perspective on economics. ${ }^{40}$

By the time he wrote Left Wings Over Europe, Lewis's opinions regarding Nazism and fascism had not changed significantly, but his continuing reinterpretation of the political landscape reveals a new iteration of the kulturkampf:

\footnotetext{
${ }^{36}$ Ibid., 158.

${ }^{37}$ Ibid., $165-73$.

${ }^{38}$ Ibid., 162.

${ }^{39}$ There are no books or articles devoted to the question of Lewis's economic views.

${ }^{40}$ In the story "Parents and Horses" from Rotting Hill, Lewis (as narrator) displays some sympathy for the anti-usury views of the fictional Rev. Matthew Laming, as they are represented in Laming's unpublished book, The English Church and Usury, remarking, 'The word 'usury,' it must be realized, does not refer to that minor nuisance, the trade done beneath the familiar sign of a trinity of brass balls. The Banks and Insurance Companies, the coiners of false credit, the whole of the iniquitous Credit system, is what is involved-the chairman of your bank is an arch-usurer." Lewis, Rotting Hill, 247. In The Human Age, Pullman sees the representatives of International Capital and the Symbolic Britain on display in a punishment centre of Dis. Lewis, Malign Fiesta, 411-415. When the Symbolic Britain accuses Dr. Hachilah of being a communist, Hachilah responds, "“This man is the kind of fool who thinks that only Stalinists frown on Usury .... The Christian Church had for centuries legislated against it." Lewis, Malign Fiesta, 414. Of course, Hachilah represents the views of Sammael, so this may also imply a criticism of anti-usury thought.
} 
At present the whole world is about to split, and, I am afraid, to contend, for a very long time, upon a very great issue indeed. It is a far greater issue than that of party. This is obscurely recognized by the generality; the 'march of progress', the immense development of the technique of science, the breakdown of the present 'capitalist' system (for plainly half the world cannot remain out-of-work for ever)-everything seems to indicate some great turning-point in life upon this planet.

The real nature of the issue is very little understood. It goes under a variety of confusing names. But it has to do, perhaps first and foremost, with two capital conceptions of man and his destiny.

The sort of society for which one set of men are heading, whether they know it or not, is a mechanical, standardized society of robots conveniently mesmerized by slogans-worn down, all over the earth, into a monotonous consistency, until we are all as like as two peas. And the sort of society for which another set of men are heading is the opposite-one in which there is diversity and individual initiative. The former is the outcome of an almost mad predilection for the abstract and the theoretic. The latter is the outcome of a sane and rational appetite for the concrete and the real. ${ }^{41}$

As Lewis presents the situation in Left Wings Over Europe, both the communist and liberal-democratic world-powers are seeking to create a universal "society of robots" in which peace will be achieved through the minimization or elimination of all potentially divisive differences between people. Lewis focuses on the implications of the Russian

\footnotetext{
${ }^{41}$ Lewis, Left Wings Over Europe, 21-22.
} 
diplomat Maxim Litvinov's famous remark that "Peace is indivisible"; he comments that if such is the case, then "everything else would be indivisible, too. All that would remain to be decided is who should control this one and indivisible human society-raceless, classless, nationless, and even individual-less. ${ }^{, 42}$ As Lewis sees it, the answer has already been decided: "Moscow and Geneva are but two heads of the same 'indivisible' animal." ${ }^{23}$ The result, presumably, would be something akin to Alexandre Kojève's vision of the "universal and homogenous state," where peace and tolerance reign, but all noble human virtues have been extinguished. ${ }^{44}$ The 'Extremist of the "Right", ${ }^{45}$ on the other hand, stands, according to Lewis, for the "small man," the "creative worker," and the "concrete capital of agriculture and industry," against "Big Business," and the "superusury of International Finance. ${ }^{.46}$

The political Left-which seems to include, for Lewis, most liberal-democrats, whether they are conscious of their allegiance or not-desires a new war that will destroy what remains of Western civilization, so that their "indivisible" world-society can be created: "The extremist of the 'right' understands very well-as does his 'leftie' antagonist, too, naturally-that a new Great War would clear the way for a return to primitive conditions-to really primitive conditions; the tabula rasa which is the desideratum of the marxist. ${ }^{, 47}$ Lewis, of course, considered himself to be essentially a "a

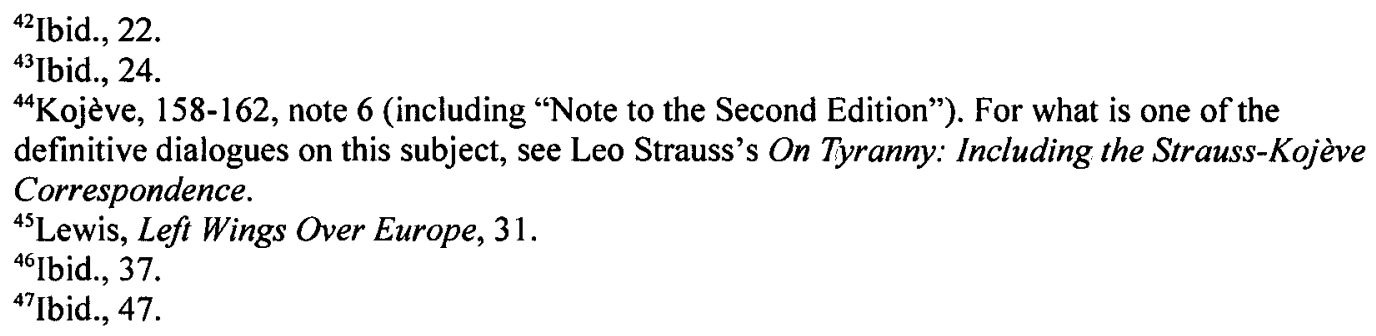


man of the tabula rasa both in art and politics, ${ }^{, 48}$ but the world-society he envisioned--based upon Proudhon's idea of an unstable equilibrium-differed significantly from that of either the communist or the liberal-democrat, and would have to be achieved through means other than war. Lewis, then, sees a potential ally in the fascist powers, as they, according to his view of the situation, have an interest in maintaining peace-even if it is of an unstable, rather than "indivisible," variety.

In Left Wings Over Europe, Lewis's suspicions regarding third-party conspirators, first addressed in Hitler, have solidified into conviction, and he goes as far as to blame the Great Depression on a hidden group of people who have an interest in worldeconomic collapse: "[The Great Depression] had its origins in human-perhaps subhuman-brains all right. It was somebody, or some class of people, who caused it."49 Speculating upon the intentions of this hidden class of people, he suggests that the Depression also served to further the progress of the creation of an oppressive worldgovernment: "This Great Depression-the 'Economic Blizzard'-has been compared with the Russian Revolution. That is not, I think, so wide of the mark. It was a complementary event, perhaps. It may have been intended to complete the work the Russian Revolution . . began." ${ }^{90} \mathrm{He}$ adds, however, that it has had the unforeseen effect of aiding the Nazi revolution, and thus sees in Nazism and fascism the possibility of a counter-revolution. ${ }^{51}$ In Left Wings Over Europe, Lewis defends the fascist world-powers not because he sees a world state as the ultimate evil, but because he fears a specifically communist and "indivisible" world state-one in which the unique personality of the creative

\footnotetext{
${ }^{48}$ Lewis, The Mysterious Mr. Bull, 230.

${ }^{49}$ Lewis, Left Wings Over Europe, 109.

${ }^{50}$ Ibid., 109.

${ }^{51}$ Ibid., 109.
} 
individual would be crushed, and art (among other things) would consequently cease to exist. Using the political materials that were at hand, Lewis positioned fascism against communism as a counterbalancing influence, hoping to forge the basis for a new political equilibrium. Perhaps realizing that his argument, drawn largely from analysis of international events, might be unconvincing to the average Briton, Lewis chose to focus on its implications within the British political sphere in his next polemical work, Count Your Dead: They Are Alive!.

Count Your Dead has received little serious discussion or analysis, apart from a chapter in D.G. Bridson's The Filibuster, and the general critical consensus is that it represents the lowest point of Lewis's political pamphleteering. Paul Edwards, for example, writes that it is "Probably his worst book," alleging that "the version of history put forward in it simply duplicates Nazi conspiracy theory." ${ }^{92}$ It is my opinion that Count Your Dead is not one of Lewis's worst books, and that the discourses which it is aligned with go far beyond "Nazi conspiracy theory" and display the complexity of Lewis's engagement with the Rightist discourses of the period. In it, Lewis reveals an intended audience of his 1930s evangelicalism, and, in turn, illuminates one of the practical goals of both his intervention in the British kulturkampf of the 1930s and his sympathetic appraisal of fascism.

The book takes the form of a fictional posthumous tribute to a character named Launcelot Nidwit, a recently-deceased Tory clubman, by a friend known only as "Ned." Much of the book consists of Launcelot's personal notes or "thoughts," which have been

${ }^{52}$ Edwards, Wyndham Lewis: Painter and Writer, 389. 
compiled by Ned, who prefaces them with an introduction and a three-part "statement." Thus, the reader is provided with an intimate look into the thought-processes of each character.

Ned is a particularly complex character-part conservative, part leftist, part fascist, part credit-crank. His political philosophy emerges from his observation that "All effective political power in England is non-democratic,",53 and that what the public is allowed to know, through the media, is part of a façade of misrepresentation. Furthermore, Ned alleges that Launcelot's brand of conservatism is an integral part of this façade. Ned advises the reader, "That this present system is from top to bottom $a$ fake antique, that is first and last what I should recommend you to ponder," $" 54$ and describes the stereotype of the unintelligent but honest Englishman as "the perfect decoyduck." ${ }^{\prime 55}$ Ned sees the mainstream Conservatives, duped by their own "Johnbullism," as he calls it, ${ }^{56}$ as drifting towards an anti-fascist and pro-Leftist position while believing they are in control of the political situation. ${ }^{57}$ The Left are victims of another, related illusion, as they see the mainstream conservatives as their enemies, despite the fact that they are both working towards the same goal. The Left/Right conflict within the domestic kulturkampf only serves to drain needlessly the energy of both parties, thus facilitating political drift. Ned asserts that "The present Fake Antique, typified by Colonel Blimp, is an Aunt Sally merely for the Marxist coconuts of Mr. David Low. Its 'Distressed Areas' might almost have been put there — might almost be preserved —on purpose to oblige

\footnotetext{
${ }^{53}$ Lewis, Count Your Dead, 35.

${ }^{54}$ Ibid., 29.

${ }^{55}$ Ibid., 21.

${ }^{56}$ Ibid., 26.

${ }^{57}$ Ibid., 47.
} 
Marx.. ${ }^{158} \mathrm{He}$ describes all the members of this Leftist/Conservative coalition (embodied in the National Government itself) as "Bolsho-Tories," 59 for although they are locked in conflict, their enmity is based on merely superficial differences.

Ned also considers himself a Bolsho-Tory, but in his case the idea represented by the term is significantly qualified. He remarks, "I am an anti-Russian Bolshie; and I am an anti-J. Bull Tory, ${ }^{, 60}$ meaning that he is revolutionary without being Marxist, and conservative without attributing value to the fake antique. Speaking of the fake antique, he expresses hope that "one fine day conservatism itself (of which it is regarded as the inseparable associate) may recognize it as a hideous enemy. ${ }^{, 61}$ It is fitting, then, that according to Geoffrey Wagner, the original title for Count Your Dead was The Death of John Bull, but was "erased from the title page of the first part of the manuscript." ${ }^{.62}$ In Count Your Dead, Lewis, through the character of Ned, is essentially calling for the death of John Bull and the creation of a new Toryism-one with revolutionary potential.

Ned suggests that the fake antique of John Bull Toryism can be fought through the development of a new nationalism that would allow England to become, once again, "A Sovereign Nation, whether Mr. [Clement] Attlee liked it or not." ${ }^{\prime 63}$ Such a transformation—-from Bolsho-Tory internationalism to anti-communist and anti-John Bull nationalism - may come about, Ned suggests, through the application of what is referred to frequently in the text as "castor oil." ${ }^{.64}$ This castor oil metaphor is a reference

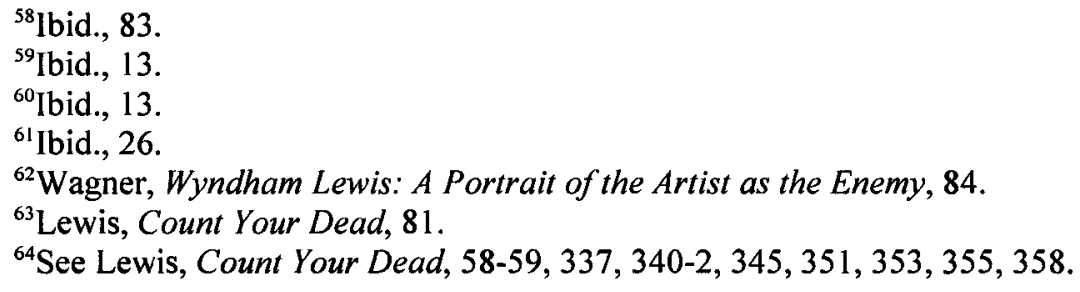


to a technique used by fascist squads in Italy in the early years of the movement: the forced administration of castor oil to political opponents. ${ }^{65}$ In Count Your Dead, castor oil emerges as an aspect of the "not-self," or objective reality, ${ }^{66}$ the implication being that for conservatism to abandon its Johnbullism, it must learn to deal with the facts of modern political life. Because they fear facing the truth, the slogan of the mainstream conservatives has become, in the words of one of the book's section headings, "Better Communism than Castor Oil." ${ }^{67}$ They are willing, in other words, to ally themselves with communism rather than face the political challenges posed by fascism.

Ned suggests that the castor oil prescription is needed particularly in the realm of economics, and that mainstream conservatism should learn from the economic example of fascism. He outlines a division (familiar to readers of Left Wings Over Europe) between what he refers to as "Monopoly versus Anti-Monopoly," or "Indivisible Economy

\footnotetext{
${ }^{65}$ See page 106 of Jasper Ridley's Mussolini, and page 52 of Claudio G. Segrè's Italo Balbo: A Fascist Life. Ridley describes the fascist use of castor oil as follows: "Sometimes they [the early fascists] forced Socialists and Communists to drink castor oil, causing them to have diarrhoea. The ex-servicemen knew about castor oil from the army, where it had been used during the war by medical officers. It was widely believed that the castor oil was [Italo] Balbo's idea, but there is no evidence of this. The castor oil has attracted much attention because of its originality and coarseness, and it has also been used as a kind of excuse by apologists for the Fascists .... The castor oil is contrasted with far more terrible methods employed by the Bolsheviks in Russia and the Nazis in Germany." Ridley, Mussolini, 106. Lewis uses castor oil as something of an "excuse" in Left Wings Over Europe, although he mistakenly attributes the castor-oil techniques to the Nazis when comparing the Nazis and the Russian communists. He writes, "Where the Nazis have, we are told, used castor oil as a corrective for political dissent, the Russian communists have gouged people's eyes out." Lewis, Left Wings Over Europe, 130.

${ }^{66}$ Lewis does not explicitly link castor oil with objectivity but the implication is clear when Ned is describing the effect of pro-British propaganda on the average Englishman: "The patient is cured of the ravages of truth, or truth is held at bay, by psychological manipulation. A highly subjective condition is induced. Subjectivity-the British brand-is praised to the skies. And all that is objective, that is to say all that is not-self, is never admitted to his consciousness until it has been neutralized, and stated in terms of his private mind. That a window should be thrown open somewhere, and a few currents of fresh air allowed to penetrate this stuffy atmosphere, appears to me obvious. For so much subjectivity is suffocating." Lewis, Count Your Dead, 26. For this "patient," presumably, the proper cure is castor oil, rather than "psychological manipulation." ${ }^{67}$ Lewis, County Your Dead, 58.
} 
versus Individual Economy, ${ }^{, 68}$ and suggests that fascism is on the side of the Individual Economy in that it opposes the establishment of a monopolistic international monetary system and favours nationalized economies. He offers the following statement in support of fascism, which echoes Lewis's own published statements from a contemporaneous article, published in the British Union Quarterly (the journal of the British Union of Fascists):

Fascism is a revolt of the People. A revolt against debt. I am no Fascist. But I love Freedom. Also I hate Usury.

If Fascism triumphed the credit-web that has spread itself over the earth would be broken, and the big abstract money-spinner at its centre killed. ${ }^{69}$

Fascism is thus worth paying attention to because it represents the only organized resistance to internationalism and the "indivisible economy," while capitalism and communism are both devoted to the creation of a "cosmopolitan super-state." Ned even proposes the novel thesis that communism is merely capitalist usury taken to its ultimate extreme: “if 'Loan-Capital' were allowed to proceed on its way without interference, it would automatically result in Communism. What is Soviet Russia to-day but a vast

\footnotetext{
${ }^{68}$ Ibid., 278.

${ }^{69}$ Ibid., 276. The corresponding "word to the Fascist at large" from Lewis's British Union Quarterly article, entitled "'Left Wings' and the C3 Mind," reads as follows: "You as a Fascist stand for the small trader against the chain-store; for the peasant against the usurer; for the nation, great or small, against the super-state; for personal business against Big Business; for the craftsman against the Machine; for the creator against the middleman; for all that prospers by individual effort and creative toil, against all that prospers in the abstract air of High Finance or of the theoretic ballyhoo of Internationalism." Lewis, "Left Wings'," 33. Incidentally, this passage is quoted in the appendix of Eugen Weber's Varieties of Fascism, immediately after a representative quotation from Benito Mussolini. Weber's note for the appendix displays his lack of knowledge of Lewis's work. He writes that Lewis "was attracted by the more reactionary aspects of Fascism, although he expresses his sympathy in radical terms." Weber, Varieties of Fascism, 145. Is it not possible that Lewis used radical terms to express sympathy for the radical aspects of fascism? ${ }^{70}$ Lewis, Count Your Dead, 324.
} 
pawnshop? It is the bodies and minds of the people that are in pawn, too."71 The archenemy of the anti-monopolist (whether he be fascist or not), according to Ned, should be the American Federal Reserve, or central bank, which he claims is " "the apotheosis of the bankers' power, and is to-day the most powerful single institution in the world'."72

Ned asks British conservatives to reexamine their fundamental principles in light of the political problems that fascism proposes to solve, his message being that conservatism and internationalism are incompatible, because while the former stands for economic self-reliance, the latter stands for a global economic interdependency that can easily become tyrannical. ${ }^{73}$ His vision of European harmony is one of separate, sovereign states with separate economies, free of the so-called "credit web" of international finance, the centralizing power of the League of Nations, and insidious Marxism.

Ned force-feeds his vision of European politics to the hapless Launcelot, and the reader is given an intimate glimpse into Launcelot's "thoughts" as his semiotic reality becomes increasingly confused and fragile. As a result of his recorded conversations with Ned, Launcelot's vision of the Left/Right kulturkampf of British domestic politics gradually gives way to a more refined vision of a Europe-wide kulturkampf. He begins to recognize that his Toryism is merely part of an artificial facade, and that his unthinking mistrust of Germany is the result of anti-German propaganda concocted by those with an interest in starting a new war. Ned encourages Launcelot's conversion, inspiring Launcelot to adopt Pauline rhetoric when he writes that Ned promises "The blinkers would drop off my eyes. Instead of seeing things through a glass darkly I should see them

\footnotetext{
${ }^{71}$ Ibid., 17.

${ }^{72}$ Ibid., 286.

${ }^{73}$ Ibid., 297.
} 
face to face. ${ }^{, 74}$ Eventually, Ned's castor oil prescription becomes too much for Launcelot to bear, and when the blinkers do finally fall from his eyes, he lapses into psychosis. The political revelation he experiences manifests itself as a psychosomatic illness:

Something's muscling-in on my innards. Down in the pit of the stomach. From left to right, and back again. This is not a Thought. It's a Pain!

Of course I know perfectly well what it is. It's an imaginary dose of castor oil.

It's been there for a week. I dream it's been administered to me by a great hobnailed bully, a Fascist. And when I wake up the feeling's still there, as if I'd really taken the damned stuff. ${ }^{75}$

In his last entry, he imagines himself shouting " Count your dead! . . They are Alive!"” to the people of England, ${ }^{76}$ urging them to recognize the war looming on the horizon.

It is important to recognize that Launcelot is not a Leftist or an unpolitical man; he regards himself as a Tory. Interestingly, the significance of Launcelot's Toryism is noted in a brief but insightful review from The British Union Quarterly. In discussing the character of Launcelot, the reviewer praises Lewis for his unusual choice of "hero":

A less capable writer [than Lewis] would have selected his medium from the ranks of the Left Wing parties. Such a person, reading only the carefully selected items which the Liberal and Labour papers allow to appear, could hardly avoid gaining a thoroughly distorted picture of events. It is Mr. Lewis' great triumph that his hero, Launcelot Nidwit, is in possession of all the facts of the case, and simply dismisses those which conflict with the opinion which has been instilled

\footnotetext{
${ }^{74}$ Ibid., 142.

${ }^{75}$ Ibid., 351 .

${ }^{76}$ Ibid., 358.
} 
into him. His reasoning that, when Reuters declares that "Paris thinks so and so," "Paris" means only Madame Tabouis, and that she represents simply and solely the Soviet Embassy, is, in fact, in advance of that of the average man. Again, he has an unusually good memory, and can recall the numerous occasions when he has been beguiled before. But this does not prevent him from swallowing with great gusto the next ration of anti-Fascist dope. ${ }^{77}$

Launcelot, the reviewer implies, is not entirely a dimwit. He is, in fact, reasonably intelligent, and his Toryism steers him away from the strictures of leftist ideology, yet he allows himself to be fooled; it is implied that eventually, his ingestion of the castor oil supplied by Ned may allow his mind to reject the "anti-fascist dope" that has kept him in a state of semi-imbecility.

The relationship between Ned and Launcelot represents an enactment of Lewis's evangelical urge to convert the average Tory clubman. Ned, like Lewis in The Old Gang and the New Gang, seeks to create ideological confusion in the mind of the recipient of his wisdom, dirempting the conventional idea of the kulturkampf until it assumes new forms, and contains new dimensions. Thus, although Ned is the character who most closely echoes Lewis's own views, Launcelot is equally important; he represents a segment of the British population that Lewis sees as being capable of producing real social change, if only they will allow themselves to be purged through his castor-oil prescription.

Although Ned is in many respects Lewis's avatar, it would be a mistake to assume that no other models existed for Ned's character. The vision of a new

${ }^{77}$ E.D.H., Review of Count Your Dead, 100. 
conservatism proposed by Ned, which appears in embryonic form in Hitler and Left

Wings Over Europe, was shared by a loose coalition of thinkers in the 1930s that has sometimes been referred to as espousing the ideology of "revolutionary conservatism." Jay P. Corrin has studied this group to a limited extent in G.K. Chesterton \& Hilaire Belloc: The Battle Against Modernity (1981) and Catholic Intellectuals and the Challenge of Democracy (2002), ${ }^{78}$ although he uses the term "revolutionary conservatism" only in passing, noting that it was first used in Seward Collins's editorial notes from the April 1934 issue of The American Review. ${ }^{79}$

Revolutionary conservatism is difficult to define, due in part to the fact that aside from an independent British Conservative party led by Lord George Lloyd, which failed in the 1935 elections, ${ }^{80}$ the movement did not have any official political representation. It was represented, however, by two important journals: The English Review and The American Review. The majority of those aligned with revolutionary conservatism, and with these journals, were intellectuals and either Catholics or adherents of something approaching T.S. Eliot's conception of "orthodoxy." ${ }^{\text {"81 }}$ Albert E. Stone Jr. identifies four

\footnotetext{
${ }^{78}$ Corrin, G.K. Chesterton and Hilaire Belloc, 163-167. See also Corrin, Catholic Intellectuals, 179-180, et al.

${ }^{79}$ Corrin, G.K. Chesterton and Hilaire Belloc, 163. In his editorial notes describing the American Review's first year, Collins describes the intent and ideology of the magazine as follows: "The magazine was founded as an experiment in securing co-operation between a number of groups and individuals none of whom has had a regular organ of expression in this country before, and all of whom represent in differing ways a single general direction in contemporary thought. The prospective contributors were described in our first issue as being 'radically critical of conditions in the modern world, but launching their criticism from a "traditionalist" basis: from the basis of a firm grasp on the immense body of experience accumulated by men in the past, and the insight which this knowledge affords.' Other descriptive phrases applied to our contributors were 'radicals of the Right' and 'Revolutionary Conservatives.' In other words, what was intended was a RightWing miscellany to undertake the unique task of presenting the opposition to the well-nigh universal liberalism, radicalism, and false conservatism of our organs of opinion." Collins, "Editorial Notes," 118.

${ }^{80}$ Corrin, Catholic Intellectuals, 180.

${ }^{81}$ Eliot, After Strange Gods, 21-22, et al.
} 
prominent "ideologies" represented in The American Review, and these categorizations generally apply to The English Review as well. The ideologies are Distributism (represented by G.K. Chesterton and Hilaire Belloc), Neo-Scholasticism (represented by Christopher Dawson and Father Martin D'Arcy), New Humanism (represented by Irving Babbitt and Paul Elmer More), and Southern Agrarianism. ${ }^{82}$ In all its variations, revolutionary conservatism offered a vigorously intellectual form of conservatism and thus was generally opposed to the complacency and anti-intellectualism of mainstream conservatism.

One of revolutionary conservatism's most defining characteristics was its adherence to a tradition of economic thought derived from Pope Leo XIII's 1891 encyclical Rerum Novarum. From this encyclical, revolutionary conservatives derived a policy of opposition to both collectivism and unrestrained capitalism, the proposed alternative being a political system that would facilitate the widest possible distribution of private property (hence the economic philosophy of "distributism" developed by Chesterton and Belloc). These ideas took a more concrete form in Belloc's influential 1912 work, The Servile State, in which Belloc argues that capitalism and socialist collectivism in England will eventually fuse together and create a monopolistic superstate; economic reforms that appear to benefit the working class-such as the establishment of a minimum wage-Belloc also suggests, instead create a condition of enslavement in that they reinforce and legitimize the distinction between employers and the propertyless employed. Ned, in fact, echoes Belloc's idea that communism and

${ }^{82}$ Stone Jr., Albert E., "Seward Collins and the American Review: Experiment in Pro-Fascism, 1933-37," 5. The Southern Agrarians included such thinkers as Allen Tate and John Crowe Ransom. Ransom, incidentally, wrote a 1929 article on Lewis's Time and Western Man, entitled "Flux and Blur in Contemporary Art." 
capitalism are on the same political track towards the creation of an international

monopoly in which "the people are in pawn." For Ned, Nazism is the revolt of a nation

that has been legislated into enslavement, and thus constitutes a strike against a

monolithic internationalism.

Lewis's sympathy for revolutionary conservatism, and the extent to which his

thought was compatible with this movement, ${ }^{83}$ can be seen in his relationship with the

two aforementioned representative journals from the period: the English Review and

American Review. The English Review, originally the creation of Ford Maddox Ford,

became from 1931 to 1936, under the editorship of Douglas Jerrold, a prominent forum

for revolutionary conservatism in England, although Jerrold referred to his colleagues as

"new Conservatives." 84 A prolific writer and publisher, Jerrold is now best remembered

as the man who arranged for the airplane that flew Francisco Franco from the Canary

\footnotetext{
${ }^{83}$ One suggestion that Lewis's thought is compatible with this brand of conservatism comes from a two-part 1931 Time and Tide article by G.K. Chesterton entitled "The Doom of Doom: A Reply to Mr. Wyndham Lewis's Articles on Youth Politics." The articles in question are those that would later be collected in Doom of Youth (1932), in which Lewis examines the political implications of the age-war of the Young versus the Old. Although Chesterton is ultimately critical of Lewis's stance, he acknowledges a certain correspondence of ideas, especially in regard to Lewis's skepticism regarding the value of feminism and the youth movement: "it is an odd coincidence that my friends and I have held, in certain obscure dens of reaction and superstition, some of the very things that he has since discovered far along the high road of innovation and sceptical enquiry. ... Mr. Wyndham Lewis, of course, has never seen the funny little rags in which we poor old reactionaries write our opinions; but he would be surprised to find how similar in some ways they have always been to his own opinions." Chesterton, "The Doom of Doom [Part 1]," 910. Furthermore, there are certainly similarities in structure and content between Chesterton's What's Wrong with the World (1910) and The Art of Being Ruled-despite Lewis's attack on Chesterton in the latter. Each offers a wide-ranging analysis of post-Christian modern Europe, with a focus on the "revolutionary" mind, socialism, and especially the rise of feminism and the cult of youth. Although they come to different conclusions, their approach to social analysis and the substance of their arguments is similar.

The only existing article regarding the connection between Lewis and Chesterton is Sheila Watson's "Wyndham Lewis and G.K. Chesterton" (1980), which examines some of the references that Lewis and Chesterton made to each other, but does not mention Chesterton's Time and Tide article.

${ }^{84}$ Jerrold, "The Future of the English Political Parties," 357.
} 
Islands to Morocco at the beginning of the Spanish Civil War. ${ }^{85}$ His monthly "Current Comments" articles in The English Review provided a running commentary on political events of the day, as seen from a revolutionary or new conservative perspective, and the authors that were published in the journal during his editorship included such prominent conservatives as Herbert Agar, Hilaire Belloc, Malcolm Muggeridge, and Sir Charles Petrie. ${ }^{86}$

Lewis was connected to Jerrold and the journal in a number of respects. If Jerrold's statement on the subject is correct (and Lewis does not contradict him in his review of the work in which this claim is made), Lewis was one of the British intellectuals that promised to support Jerrold's editorship of The English Review in $1931{ }^{87}$ Lewis published two articles in the journal during Jerrold's editorship, "Detachment and the Fictionist" (1934) and "The Big Soft Centre" (1936), and Jerrold also became, for a short period, Lewis's publisher with Eyre and Spottiswoode. ${ }^{88}$ Lewis spoke highly of Jerrold during this time-period, referring to him in Blasting and Bombardiering, for example, as "the brains of the Right ..., the [José Calvo] Sotelo of English right-wingery, . . . [and] the legitimate successor of Belloc and Chesterton. $" 89$ Lewis also wrote a highly positive review for The Spectator of Jerrold's politically-

\footnotetext{
${ }^{85} \mathrm{Jerrold}$ describes the event in pages 370-373 of Georgian Adventure.

${ }^{86}$ Muggeridge, whom Lewis praises on page 342 of Blasting and Bombardiering, wrote a highly sympathetic review of Left Wings Over Europe.

${ }^{87}$ Jerrold, Georgian Adventure, 331-332. Jay P. Corrin also claims that this was the case. Corrin, Catholic Intellectuals, 179.

${ }^{88}$ Blasting and Bombardiering was published by Eyre and Spottiswoode in 1937.

${ }^{89}$ Lewis, Blasting and Bombardiering, 342. It should be noted that around the time of the publication of Blasting and Bombardiering, Lewis had a falling out with Jerrold that ended their literary relationship. According to Jeffrey Meyers, Lewis became hostile to Jerrold in part because Jerrold "insisted on being mentioned in the memoirs." Meyers, The Enemy, 232. Lewis's enthusiasm regarding Jerrold in Blasting and Bombardiering and his review of Georgian Adventure may be simply a case of strategic flattery, but given Lewis's general disregard for the opinions of others, this seems unlikely.
} 
charged 1937 autobiography Georgian Adventure, and it is clear from this review that Lewis understood Jerrold's position in relation to mainstream conservatism. He refers to the book as "one long cry of revolt" and writes that "Mr. Jerrold knows how he should act, according to his rebellious premises, and yet acts differently-for one feels that he is conscious that his conservatism is in the sharpest contradiction with his tragic experience of what conservatism can do." ${ }^{.90}$ At the end of 1937, Lewis had a falling out with Jerrold over Jerrold's handling of the publishing of Blasting and Bombardiering, ${ }^{91}$ but nevertheless some ideological affinity and a relationship of mutual support existed between the two up to that point.

The most prominent American journal of revolutionary conservative opinion was The American Review, which lasted under the editorship of Seward Collins from 1933 to 1937. Lewis's presence in the review has special significance, for as Albert E. Stone Jr. argues, Collins selected articles with a mind to creating a unified revolutionary conservative front: "It was Collins' purpose to print only articles that had been carefully solicited in advance; by far the largest number of contributions were obtained in this fashion. Hence virtually every political article that appeared had Collins' personal sympathy and usually his approval. Each was designed to play its part in the propaganda campaign he was conducting." 92

Lewis's essay on Ernest Hemingway was published in the review, ${ }^{93}$ as was a compilation of excerpts from Count Your Dead, with an enthusiastic introduction by

\footnotetext{
${ }^{90}$ Lewis, "Rebel and Royalist," 553.

${ }^{91}$ Lewis to Douglas Jerrold, Notting Hill Gate, December 1937, in Rose, ed., The Letters of Wyndham Lewis, 248-249.

${ }^{92}$ Stone Jr., Albert E., 4.

${ }^{93}$ See Lewis, "The Dumb Ox: A Study of Ernest Hemingway."
} 
Collins. ${ }^{94}$ Geoffrey Stone, a future friend of Lewis, published a two-part survey of Lewis's work and a lengthy review essay on Left Wings Over Europe. Stone's survey is particularly revealing, as he places Lewis within what he refers to as the "great ... antimodern movement": "On the whole he [Lewis] allies himself with tradition rather than against it; he is part of the great—great in the vigour of its personalities if not numerically—anti-modern movement which includes such diversified figures as Julien Benda, Charles Maurras, Paul Elmer More, Jacques Maritain, G.K. Chesterton, Nicholas Berdyaev, T.S. Eliot, Douglas Jerrold, and the late Irving Babbitt. ${ }^{\text {"95 }}$ Stone also suggests that Lewis's ideas on economics are compatible with Distributism, even if Lewis appears to be hostile to Chesterton and Belloc as literary personalities: "what attracts him [Lewis] in Hitler's economic theories is, strangely enough, what he might find in even more congenial form in the writings of Hilaire Belloc and G.K. Chesterton-for whom he expresses the most decided dislike, based apparently on a superficial acquaintance. ${ }^{.96} \mathrm{In}$ his later review of Left Wings Over Europe, he draws a similar correspondence between Lewis's interpretation of Nazism and Distributism: "Mr. Lewis is worth quoting at this length because he gives expression, in his amazingly flexible and informal style, to a point of view which is too rarely advanced in England and America. In fact, a leading exponent of the Nazi as a sort of groping Distributist has been Mr. Lewis himself, who,

\footnotetext{
${ }^{94}$ Collins, in his introduction to the excerpts from Count Your Dead, writes that "Wyndham Lewis is without doubt the foremost literary artist in our language who is devoting himself to the defense of ideals that have always been the underlying aspirations of Americans; and this at a time when most of our intellectuals and littérateurs have been succumbing to ideals utterly hostile to and destructive of the central American tradition-and, moreover, have been highly successful in carrying predominant opinion with them." Collins, "Wyndham Lewis's New Tract for the Times," 266.

${ }^{95}$ Stone, "The Ideas of Wyndham Lewis," 578.

${ }^{96}$ Stone, "The Ideas of Wyndham Lewis: Part II," 93.
} 
in 1930, gave a thoughtful account of German National Socialism in his book Hitler."997 Whether or not Lewis was familiar with the economic theories of Belloc and Chesterton—and references to Belloc's Servile State in both Left Wings Over Europe and Count Your Dead show that he may have been-it is clear that Stone thought that Lewis's economic ideas, or at least his appropriations of Nazi economic theory, were compatible with Distributism. $^{98}$

By linking Hitler, Left Wings Over Europe, and Count Your Dead to revolutionary conservatism, I am not suggesting that revolutionary conservatism represents the only political discourse with which Lewis aligned himself during this period of the 1930s. It shows, however, that in Lewis's interventions in the kulturkampf of the 1930s, he had at least one specific audience in mind. In Count Your Dead he hoped to encourage the revolutionary conservatives (or the Neds) in their efforts to awaken the traditional Tories (the Launcelots).

In all of his 1930s polemics, Lewis attempted to expand the collective British political consciousness, so that it might transform itself into something beyond the simplistic kulturkampf between the Left and the Right, or the Old and the New. Fascism, as Lewis saw it, was a novel political medicine that could be administered, like castor oil, to the representatives of a decaying political system. Lewis's diremption of Nazi ideology in Hitler provided ideological materials for possible incorporation into the British political system; Left Wings Over Europe, and especially Count Your Dead, presented the case for a new conservatism, revitalized by fascist influence. Revolutionary

\footnotetext{
${ }^{97}$ Stone, "A New Book by Wyndham Lewis," 570.

${ }^{98}$ Lewis, Left Wings Over Europe, 55-6; Lewis, Count Your Dead, 59.
} 
conservatism, during its brief ascendancy, showed that Toryism could rid itself of its hollow reactionary impulses and absorb the ideological innovations that fascism appeared to be offering. Lewis's proposals did not cause as much of a political stir as they were perhaps meant to, but his connections to the representative journals of this movement suggest a system of mutual admiration. They also represent, perhaps, a rare instance of a contribution on the part of Lewis to an existing British political movement-albeit an indirect contribution shrouded in the outsider mystique associated with the politics of the intellect. 
Chapter Four

"II Wish to Be an Integral Social Being"": The Post-War Kulturkampf and the Fate of the Clercs in Rotting Hill

Lewis's intervention in the kulturkampf of the 1930s had virtually no political effect and only served to damage his reputation. In 1939, after attempting to make amends to the British public by writing a critique of anti-Semitism (The Jews: Are they Human?) and a polemical re-evaluation of Hitler (The Hitler Cult), Lewis went into self-imposed exile in the United States and Canada for the duration of the Second World War. In 1945, he returned to England from Canada and found himself living under the post-war Labour government of Clement Attlee, which lasted until 1951. Rotting Hill, a collection of stories published in 1951, and one of the many works Lewis published upon his return to England, is a fictional account of life in Notting Hill and the surrounding area during those years. In these stories, Lewis portrays the Attlee government as representing the penultimate phase in the historical progression of socialism from its roots in Protestant Christianity to an atheistic, totalitarian communism. Within the environment of Attlee's England, Lewis interacts (both as narrator and implied author) with the human remnants of the kulturkampf of the 1920s and 30s, offering literary snapshots of these ghostly, tragicomic personalities, who with rapidly-declining energy fight the state, each other, and themselves.

Lewis's authorial persona differs from its earlier incarnations: no longer the selfdeclared "Enemy"-figure of the late 1920s or the political provocateur of the 1930s, Lewis presents himself as a friendly intellectual studying the political battles of the middle class. These battles most often take the form of uninformed and emotional 
rhetorical debates, but Lewis once again implies that the study of their mechanics can provide a map of the political landscape that the intellectual-who is always, for Lewis, an outsider in the world of politics — can use as a guide when negotiating with society at large.

Despite the change in his authorial persona, in the first-person stories of Rotting Hill, Lewis stealthily resurrects his evangelistic model, his goal again being to inspire an intellectual conversion in select members of the middle class-a conversion meant to transport them outside the kulturkampf. The impulse behind his partially-submerged evangelism is neatly summarized in his statement in Rude Assignment (1950) that "Criticism is merely the introduction of the outside light into a dark place. Outsideness is to be where the light is." Fresh from his experiences in the distinctly un-European cultural landscape of North America, Lewis presents himself to his countrymen as a representative of "the outside light," seeing his goal as not the transformation of society, but the political emancipation of those few who will take the time to listen. This evangelism, however, is tempered by Lewis's post-World War II attitude of caution in regard to political matters-a reflection of the lessons learned from his sympathetic appraisal of fascism in the 1930s.

Because Lewis approaches his subject matter in Rotting Hill from the perspective of a political outsider, it is important to distinguish between the narrator's private dialectical musings and the provisional rhetorical statements he makes in conversation with other characters-a task that is often difficult. As in much of Lewis's earlier work, his strategy of non-partisanship functions as both a frustrating obstacle for his perennial

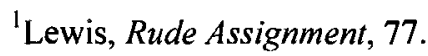


literary nemesis, the politicized or ideologically-driven critic, and as a form of resistance against the political itself. Instead, however, of evading the friend/enemy division of the political by assuming the persona of the enemy-of-all, as he does in much of his 1920s and 30s work, Lewis acts as a friend-of-all by projecting an aura of humility and openness. Although his stoical attitude towards post-war political developments often amounts to political pessimism, his gentle non-partisan stance represents a kernel of resistance-an alternative to the absolutist Hegelian-Marxist dialectic and violent working-class resentment that he saw in the politics of the atomic age.

Rotting Hill must be read within the context of the development of Lewis's thought during the years following World War II. A superficial survey of this period in Lewis's career shows a significant change in his political course, but many of his older political preoccupations appear again, albeit with subtle modifications. America and Cosmic Man, a 1948 study of American history and society, for example, seems to represent one of Lewis's most radical changes of political orientation, offering a vision of a future global society based on the American model. ${ }^{2}$ There is evidence, however, that Lewis's espousal of a liberal-democratic world-state was based on strategic political realism rather than idealism. In a letter regarding the book addressed to the American Catholic convert Geoffrey Stone (formerly of The American Review), Lewis adopts a conciliatory tone, knowing that the book's arguments will clash with Stone's traditionalism:

\footnotetext{
${ }^{2}$ The most insightful existing study of this book is Dennis Brown's "Prophesying the Postmodern: Wyndham Lewis's America and Cosmic Man." Brown reads the text as prefiguring many of the themes of postmodernism, as well as Francis Fukuyama's The End of History and the Last Man (1992) (the thesis of which is largely derived from Alexandre Kojeve's Introduction to the Reading of Hegel [1947]).
} 
Tomorrow I will send you a copy of my American book. . . . The Presidents I discuss you would see with a very different eye-I will not say tory, for you are not that, but traditional. ... And my "cosmic man" will probably give you a pain in the neck. You must remind yourself that what I recommend is a matter of expediency only-of necessity, I think-not what I should myself enjoy. The choice to my mind is a black one, between (1) cosmic or universal man: or (2) no man at all. The earth is too small to sustain all the old romantic tribal and national identities.

In the same way my liberalism is, in the XXth century a question of force majeure. Social justice must be practised very actively, if the world is not to be gobbled up by communism. ${ }^{3}$

If Lewis's statement can be taken seriously, then there is very little difference between his support of fascism in the 1930s and his 1940s and 50s Americanism; in each case, Lewis sympathized with an established political philosophy of which he was not necessarily in intellectual accordance because he saw it as the only possibility for the survival of humanity and the intellect.

Lewis's next published work was the career-spanning Rude Assignment: An Intellectual Autobiography, which he describes as "a book of counter-polemics." The book contains many of Lewis's most elaborate discussions of the nature of politics, the "politics of the intellect," and the role of the artist, with only a smattering of biographical information of the kind found in his earlier autobiography, Blasting and Bombardiering.

\footnotetext{
${ }^{3}$ Lewis to Geoffrey Stone, London, 21 September 1948, in Rose, ed., The Letters of Wyndham Lewis, 457-58.

${ }^{4}$ Lewis, Rude Assignment, 155.
} 
In one section of Rude Assignment, Lewis seeks to correct misinterpretations of the message of The Art of Being Ruled. He offers the following clarification of the message of that work:

To avail themselves of the spectator's privileges, 'detachment' and 'passivity' (wherever the choice is open to them): such is the advice offered to men in general [in The Art of Being Ruled]. In a word, something like the apathy of the Stoics is what you will find as the central doctrine of this book. In that consists the true 'art of being ruled.'s

This statement is somewhat misleading, for it is clear in The Art of Being Ruled that Lewis does not expect "men in general" to adopt this position of political apathy en masse; rather, Lewis's aim in The Art of Being Ruled is to rescue a small number of potential "natures" from the vast sea of "puppets." Lewis's misrepresentation of the intentions behind The Art of Being Ruled, however, reflects a subtle change in the scope of his evangelicalism, and suggests an increasing sympathy for the average man.

The change in Lewis's attitude towards the average man surfaces again in a chapter of Rude Assignment that Lewis devotes to refuting the idea that he is " Mister Ivory Tower"

Why on earth should an intellectual ... wish to associate with the Philistines? Surely that would be most uncongenial company for him!-He does not, of course, wish to do that. The best variety of intellectuals, on the other hand, are by no means enamoured of the Ivory Tower. They do not want to speak to the stars, but

\footnotetext{
${ }^{5}$ Ibid., 183.

${ }^{6}$ Ibid., 107.
} 
to men. They merely object to their being Philistines; especially they resent people deriving merit from their barbarity: their social conscience recognises in them a vast infected area, which should not be permitted to remain as it is. They object to being denied (by means of the branding described above) the missionary's privilege to go amongst the Philistines and bring civilisation to these modern middle-class savages. ${ }^{7}$

The idea that intellectuals should not work towards separation from society is an important modification of the stance Lewis takes in The Art of Being Ruled. Lewis suggests that in taking advantage of the "missionary's privilege," the intellectual may become a clerc in the oldest sense of the word, and function as a type of cleric; Lewis thus blurs the distinction between the clerc as intellectual and the clerc as priest.

In The Writer and the Absolute (1952), which appeared shortly after Rotting Hill, Lewis expands upon some of the themes developed in Rude Assignment, focusing on the specific problems facing the writer in society. He explains the purpose of the book: "What I wish to show is precisely the kind of subjects that a writer-in a transitional society-may (1) without danger of interference select-that he is free to select: and (2) the kind that he is NOT free to select: that he treats of at his peril.." Politics, according to Lewis, is something that the intellectual "treats of at his peril." He understands, however, that politics are inescapable in the twentieth century, and in response to this ever-present danger Lewis calls for unity among the clercs: "My idea would be ... to strengthen the organization of what used to be called the 'Republic of Letters.' I should advise that the

\footnotetext{
${ }^{7}$ Lewis, Rotting Hill, 15-6.

${ }^{8}$ Lewis, The Writer and the Absolute, 7.
} 
last precarious refuge of the civilized intelligence, the small world of writers (scholars and members of the teaching profession being of course an indispensable part of this not very easily demarcated whole) should somehow acquire a better sense of corporate responsibility." As in Rude Assignment, in calling for a corporation or syndic of intellectuals, Lewis does not expect the clercs to maintain an attitude of absolute detachment, but merely one of tolerance and moderation. He describes the writers who would form "the hard part of the literary body": "They may be religious men: but they do not make a parade of their piety by way of self-advertisement: they may not believe in the existence of God, but are not always speaking of His 'absence'; they may somewhere in their minds nurse this or that theory of the State, but knowing their judgements to be fallible, it does not infest their writings with a feverish passion." ${ }^{10}$ In other words, to commit oneself to a political position requires a level of intolerance that is incompatible with true intellectualism; a corporation of intellectuals must allow for the reasoned articulation of all varieties of opinion.

In The Writer and the Absolute, Lewis at times appears to go so far as to preach political pessimism, as when he writes, "It is completely useless inveighing against wars and revolutions. For my part I shall never waste my breath talking about war or other forms of organized violence. There will of course be a war again soon, just as there will be another thunderstorm before August is out.-'The Atom Bomb?' Naturally!"'। Crucially, however, Lewis does not advocate total political inaction. Although he has little faith in mankind's ability to avert war, he maintains that it is important to act

\footnotetext{
${ }^{9}$ Ibid., 52-3.

${ }^{10}$ Ibid., 53.

${ }^{11}$ Ibid., 70.
} 
politically on a restricted level. At one point he asks, "Has what I have just been saying been intended as an answer to the pacifist? And is my conclusion that we should do nothing whatever then?-To that I should answer that many persons in their private life can exercise a restraining influence-mitigate the horrors to a small extent. I for instance attempt by my books to diminish, by however contemptible a fraction, the massive confusion." 12 The implied distinction that Lewis makes between the public and the private is crucial to the evangelistic model presented in Rotting Hill, and may be understood in comparison with Carl Schmitt's idea of the political. Schmitt emphasizes that the political is a public phenomenon, and that it cannot, strictly speaking, exist in the private realm alone:

The enemy is not merely any competitor or just any partner of a conflict in general. He is also not the private adversary whom one hates. An enemy exists only when, at least potentially, one fighting collectivity of people confronts a similar collectivity. The enemy is solely the public enemy, because everything that has a relationship to such a collectivity of men, particularly to a whole nation, becomes public by virtue of such a relationship. ${ }^{13}$

Lewis advocates a shift in political activity from the public to the private, which according to Schmitt does not amount to politics at all; it is rather a subversion of the political itself through acts of private resistance. Although Lewis's books may be public by nature, he claims that he is not using them to inflame public opinion, and presents himself as one individual speaking to other individuals or potential individuals.

\footnotetext{
${ }^{12}$ Ibid., 71.

${ }^{13}$ Schmitt, The Concept of the Political, 28.
} 
Along with his outsider's view of politics, Lewis promotes an outsider's view of history in The Writer and the Absolute. Some of his thinking appears to have been influenced by Arnold J. Toynbee's philosophy of history, and specifically by the correspondences Toynbee draws between the decline of Athenian society in Ancient Greece and the inter-war period in twentieth-century Europe. ${ }^{14}$ At the end of a chapter on "Twentieth Century Nihilism," Lewis makes the Toynbee-like observation that "The parallel between the Europe of the 'twenties and 'thirties, and the Athens of antiquity after the Spartan Wars, is in some ways so remarkable and instructive that I will, I hope, be forgiven for providing this chapter with a sort of historic footnote." ${ }^{\prime 15}$ Lewis, basing his judgement on the authority of the classical scholarship of A.E. Taylor, sees Plato as having existed in a period in which an increasingly radical democracy was transforming into popular tyranny-the tragic result being the execution of Socrates. Lewis describes Plato as a conservative aristocrat, who eventually chose to abstain from politics in order to protect the intellect. Commenting on Taylor's assertion that the death of Socrates at the hands of the oligarchy that came to power in 404-3 B.C. "'put an end to [Plato's] own political aspirations'," Lewis remarks, "As you see, the 'lawless violence' of these militant reactionaries repelled Plato once and for all: and had he been born in the XXth Century there is no reason to believe that Fascist violence would have pleased him any better than Communist violence. It is the dilemma of the 'intellectual,' in whatever age he finds himself: for power is won by violence, and theories of the State have to cut their way over the bodies of men to power." 16 The implication is that intellectuals such as

\footnotetext{
${ }^{14}$ Lewis cites Toynbee on page 136 of The Writer and the Absolute.

${ }^{15}$ Lewis, The Writer and the Absolute, 134.

${ }^{16}$ Ibid., 135.
} 
Lewis are in a position similar to that of Plato after the death of Socrates; political apathy (at least in the public realm) and even exile are their only means of escaping persecution. Furthermore, Lewis suggests that it is necessary for the intellectual to recognize the cyclical process of history, as described by Toynbee, so that one may accept the inevitable presence of the political in human life, and the predictable forms it takes and adapt accordingly. This idea of history as a cyclical process also arises in "The Talking Shop" from Rotting Hill. Contemplating a perceived trend in British politics from liberalism towards socialist despotism, Lewis (as narrator) remarks, "It is always doctrinaire libertarianism that ushers in despotism, in classical political theory. For Aristotle this was an automatic matter of cause-and-effect. . . . It would be foolish to think we could escape the periodic despotism to which human society is subject." $" 17$ To see history as cyclical, and war and peace as essential, recurring elements in human life, makes absolute commitment to any political doctrine ultimately futile.

It is with the attitudes of moderation, openness, and stoic resignation advocated in his critical writings of the 1940 s and 50 s that Lewis engages with the post-war society of Rotting Hill, which is enmeshed in a variation of the earlier inter-war British kulturkampf. The social landscape that Lewis portrays, of course, is very different from the frenetic inter-war period-of-transition. After World War II, England entered a period of recuperation, and the kulturkampf described in Rotting Hill is in many ways a gentler one than that of 1920 s or 30 s. Lewis is dealing with an exhausted populace, many members of which are fighting old battles without being fully conscious of the global

\footnotetext{
${ }^{17}$ Lewis, Rotting Hill, 222-3.
} 
changes occurring around them. For the most part, Lewis focuses on members of the "disintegrating middle-class," between the Old and the New, or what Lewis describes in the Rotting Hill story "Parents and Horses" as "the civil war between the old order and the new order." 19 On the one hand, there are the reformers, or advocates of progress and social justice, while on the other, there are the conservatives, or those who cling to some form of traditionalism. The partisans of the New, who have taken control of the state, are busy negating their enemies.

To the fading middle-class, the battle between their loosely-defined ideas of the Old and the New continues unabated, but Lewis offers a more complex interpretation of the political divide, placing it in the context of a larger, global political conflict. What appears to be an internal, domestic battle is part of a friend/enemy configuration that extends far beyond state lines. Lewis delineates this conflict as one between two competing visions of world-government: a liberal, Christian socialism of the West, and a radical, authoritarian socialism of the East. As Lewis repeatedly points out, the socialism of the Attlee government is derived from Protestant Christianity but is moving towards the Eastern model, and he predicts that this tension between East and West, in its global manifestation, will result in a Third World War. ${ }^{20}$ Thus, the fundamental political question for Lewis is not "which is better: the Old or the New?", but "what form of socialism is best?" It is this understanding that sets Lewis apart from the people who are his objects of study.

\footnotetext{
${ }^{18}$ Ibid., 11 .

${ }^{19}$ Ibid., 250.

${ }^{20}$ Ibid., 68.
} 
In the social environment of Rotting Hill, no immediate threat of violence exists, but the political is nevertheless virtually all-pervasive. In his foreword to the collection, Lewis remarks, "If my characters are obsessed by politics, it is because today our lives are saturated with them. It is impossible for a work of narrative fiction worth reading to contain less politics than Rotting Hill."21 The post-war focus on the domestic social realm has eliminated the potential for political heroism but has allowed the friend/enemy distinction to penetrate into the most mundane aspects of everyday life. If the kulturkampf of the 1920 s and 30 s is remarkable for its intensity and ferocity, the gentler post-war kulturkampf is remarkable for the almost absurd depth of its penetration into the domestic life of the nation. In "Mr. Patrick's Toy Shop," which consists mainly of smalltalk between Lewis and a shop owner regarding the quality of post-war household goods, Lewis comments, "If I shall be dwelling for a moment upon quite trivial things, nailscissors and toilet accessories, let Socrates [sic] 'great mountain asses,' be my precedent,"22 which as Paul Edwards points out is a reference to Alcibiades' remark in Plato's Symposium that Socrates hides his profundity by talking about everyday people and things. ${ }^{23}$ Lewis justifies his Socratic approach, adding that "Yesterday a whole world of small everyday objects we took for granted: whereas today they have swollen until they have taken on portentous dimensions." 24 The cause of this swelling is the political. In this environment, a faulty, cheaply-made nail-clipper is not simply an object, but a symptom of the "rot" infecting Rotting Hill and the British welfare state as a whole. To

\footnotetext{
${ }^{21}$ Ibid., 11.

${ }^{22}$ Ibid., 206.

${ }^{23}$ Edwards, "Explanatory Notes," 327.

${ }^{24}$ Lewis, Rotting Hill, 206.
} 
complain about such shoddy workmanship is to make a provocative political statement, and the kulturkampf is partially fought through this politicization of the mundane.

The story entitled "Time the Tiger," which is one of the two third-person narratives in the book, best illustrates the effect of this politicization on domains outside the political-specifically those of love and personal friendship. It documents the fallingout of two unmarried, middle-aged childhood friends: Mark Robins and Charles Dyat. Both are middle-class; Mark is an orthodox socialist, while Charles is what the narrator refers to as a "synthetic "aristocrat""-in other words, an adherent of a vulgarized, postNietzschean idea of aristocracy. ${ }^{25}$ The story begins at a point in their lives when the political is eroding their bond of friendship. Their conversations have become routine, framed by the friend/enemy division between the Old and the New: Charles obsessively points out everything that is wrong with the goods the British public receive, such as poor quality tea, expensive cigarettes, stale bread, and inferior clothing, while Mark desperately tries to defend the policies of the Labour government and obey the law.

A turning point in their relationship comes when Charles's sister Ida, for whom Mark carries long-suppressed feelings of love, pays a visit to London. Over lunch, the three friends experience something that comes as a revelation to Mark. Stirred by Ida's presence, Mark becomes overwhelmed by nostalgia for the early 1920 s-a time before the emergence of the pressure of the political. The narrator observes that "Ideology ... was wiped off this trio who had that clean sensation the non-political have."26 After drinks, however, they broach the subject of politics and the atmosphere at the table changes

\footnotetext{
${ }^{25}$ Ibid., 165.

${ }^{26}$ Ibid., 194.
} 
radically as Ida begins spouting reactionary rhetoric. The narrator describes Mark's response: "his love transformed herself with nightmare suddenness into a Tory soapboxer. He had consented to play Romeo, and Juliet, at the critical moment, had acquired the mask of Col. Blimp, haranguing him from the moonlit balcony." ${ }^{27}$ Ida's diatribe, emerging dramatically into this politics-free environment, destroys what is perhaps the last glimmer of unpolitical emotion existing in Mark.

The theme of the conflict between love and the political is not unique to Rotting Hill in Lewis's oeuvre; it is an echo of Lewis's 1937 novel The Revenge for Love, in which Lewis suggests that personal love- between two individuals rather than between two members of the same political unit—cannot exist in a politicized world. The political, which according to Schmitt is impersonal and public by nature, sees the emergence of love in the private realm as an affront to its existential authority, and takes revenge. ${ }^{28}$ In "Time the Tiger," the revenge of the political triggers a transformative experience for Mark: after his traumatic lunch with Ida, and after Charles leaves Mark's apartment, Mark succumbs to a bout of depression, regarding which the narrator coldly comments, "These were the final pangs of Mark's rebirth into a novel age, as well as the death-throes of Ida's image."29 Mark abandons the idea of forming friendships and romantic relationships outside of the political, and begins a correspondence with Wendy

\footnotetext{
${ }^{27}$ Ibid., 196.

${ }^{28}$ Schmitt, in The Concept of the Political, remarks that "The friend and enemy concepts are to be understood in their concrete and existential sense, not as metaphors or symbols, not mixed and weakened by economic, moral, and other conceptions, least of all in a private-individualistic sense as a psychological expression of private emotions and tendencies." Schmitt, The Concept of the Political, 27-28. Dasenbrock, in his afterword to The Revenge for Love, also notes that in the world of Lewis's novel, "Power is not so easily mocked or escaped, and it has its revenge on Margaret." Dasenbrock, Afterword to The Revenge for Love, 393.

${ }^{29}$ Lewis, Rotting Hill, 197.
} 
Richardson, "a good party-woman, with a pretty face." ${ }^{30}$ The story ends with a short epistolary exchange between Charles and Mark. Mark, in his letter, suggests that Charles should "find some other correspondent," and the political emerges triumphant. ${ }^{31}$

The third-person narrative of "Time the Tiger" provides a clear outline of the parameters of the middle-class kulturkampf, but the stories narrated in the first-person outline Lewis's ideas regarding the proper position of the intellectual in relation to this conflict. If there is one idea conveyed by the first-person stories, it is that the kulturkampf, because it is structured according to competing visions of truth, can only be transcended through a non-partisan attempt to understand the political whole. Lewis makes his position clear in this regard in "The Bishop's Fool" when he remarks, "I belong to no party, seeing that, if you do, the only truth you are allowed is a partisan truth. Your judgement then must function only pragmatically. I prefer to concern myself with a non-pragmatical truth. A literature at the service of propaganda ceases to be an art: it becomes an agent of intoxication and of deception." "32 Reflecting Lewis's efforts to observe and express more than a "partisan truth," the narrator's quiet and cautious approach in the first-person stories functions as a means of delineating the parameters of the kulturkampf: he provokes the seemingly reasonable characters with whom he engages into revealing the polemical motives that underlie their speech and is able to conceptualize their polemical stances as counters within a larger dialectic. The resulting understanding of the political whole thus provides a means of defense, raising the philosophic mind to a plane upon which it may remain uncontaminated by the rhetoric of

\footnotetext{
${ }^{30}$ Ibid., 197.

${ }^{31}$ Ibid., 198.

${ }^{32}$ Ibid., 70.
} 
the middle-class mind. At the same time, Lewis attempts to plant the seeds of conversion, in order to point the characters he converses with towards a path leading away from the kulturkampf.

Two Anglican clergymen, Rev. Samuel Rymer, the subject of "The Bishop's Fool," and Rev. Matthew Laming, the subject of "Parents and Horses," represent the rhetorical extremes of middle-class political discourse. Rymer is an enthusiastic socialist with communist sympathies, while Laming is a reactionary whose ideas overlap with Catholic orthodoxy. They tend towards the opposite poles of what in the 1920s and 30s Lewis recognized as one variation of the Europe-wide kulturkampf: the conflict between Marxism and orthodox Christianity. ${ }^{33}$ In the post-war world, however, this division is no less relevant; Rymer and Laming, although they do not realize it, are on the same side, as both cling to the Christian heritage of the West despite their respective political temperaments.

Rymer is a person straddling two distinct historical periods. Lewis describes him as being "the last of a species," and "of the generation of the great fellow-travellers of the "twenties, who painted the universities pink." 34 He also suggests that Rymer has within himself the beginning of "another species"--the type of human that will exist after the modern period of transition-and describes his rectory as "the no-man's-land between our age and the darkness to come." Although Lewis presents himself as an equal in conversation, it becomes clear that his humbleness is a superficial pose: he uses the

\footnotetext{
${ }^{33}$ In Men Without Art (1934) Lewis places Catholicism and communism at opposite ideological poles: "The two most weighty figures in the world today (I do not say tomorrow) are the Pope and the Marxist Dictator; they alone are consistent, they alone are ubiquitous, and mean the same thing in one place as in another." Lewis, Men Without Art, 187.

${ }^{34}$ Lewis, Rotting Hill, 50.

${ }^{35}$ Ibid., 43.
} 
information he receives to paint a satirical portrait, constructing an image of Rymer as a limited organism with impulses structured according to the dictates of a fixed idea. At the beginning of the story, Lewis tells the reader that in describing Rymer, he will begin by analyzing Rymer's "functional essence" and the "disembodied action" that defines him: ${ }^{36}$ "Having begun with the effect I will turn to the cause; give an account of this unusual creature. ${ }^{.37}$ His statements are carefully calculated, and he performs an analysis of the mechanics of their exchange, sometimes playing the Devil's Advocate and noting the reactions his comments provoke. The rhetorical maneuvering present in Lewis's conversations with Rymer reflect the strategies of his political writings as a whole. His position as an artist-intellectual removed from politics allows him to engage with the kulturkampf in the manner of an actor, adopting political poses like masks in order to confuse and infuriate anyone who might attempt to place him within a particular friend/enemy grouping.

In order to determine the motives underlying Rymer's rhetoric and tease him into self-awareness, Lewis makes comments that force Rymer to examine rationally and to justify his political impulses. At one point during their longest conversation, he describes his method to the reader: "In this talk we were having it was my idea to say just enough to oblige him to forsake some of his romantic conventions and to adopt a more realistic attitude: or come out and defend his obscurantist absolute. ${ }^{938}$ Unlike Ned in Count Your Dead, however, Lewis avoids stating his opinions explicitly; instead, he strives to "say just enough" to provoke those with whom he converses into questioning their values. An

\footnotetext{
${ }^{36}$ Ibid., 18.

${ }^{37}$ Ibid., 18.

${ }^{38}$ Ibid., 59.
} 
example occurs when Lewis remarks upon the draconian methods used by the Russian communist leaders and Rymer is unable to respond: "To this [Rymer] made no reply. He could have argued, for instance (for even the worst cause is polemically defensible) that barbarity had marked the regimes which the revolutionary governments had supplanted, in Russia and elsewhere. ${ }^{.39}$ Lewis, because he places himself above the kulturkampf by acknowledging the polemical validity of all political opinions, anticipates what a wellschooled communist would have said, and thus finds further evidence for his claim that Rymer is essentially flirting with communism in order to make use of its modest shock value. ${ }^{40}$ He continues, "There are plenty of answers to the criticism of any policy. He is not interested in being an advocate however. He just enjoys pushing under people's noses something they detest. He does not want to find himself in the role of selling it to them, of being too serious about it. And, as I have said, he is genuinely no Red." ${ }^{941}$ From this Lewis deduces that Rymer is indulging in the appropriation of the political for the purposes of self-aggrandizement, which is a trait that Lewis found so prevalent and infuriating in the inter-war literary scene-even if he may have, in a certain manner, indulged in it himself.

Although Lewis chooses to spend more time analyzing than speaking in his conversations with Rymer, he becomes explicitly evangelical when the opportunity arises. Specifically, he urges Rymer to become aware of the totalitarian tendencies of socialism and to brace himself for a future battle between a Western, Christian socialism and an Eastern, atheistic communism. Later in the story, after alerting Rymer to the

\footnotetext{
${ }^{39}$ Ibid., 51.

${ }^{40}$ Ibid., 50.

${ }^{41}$ Ibid., 52.
} 
possibility of a Third World War, he notices that Rymer has become "deeply upset," and speculates as to the reason: "A hint that this fabric of salvation could have a fatal flaw was highly distasteful to him: the view that the very basis of socialism in Christian ethics might be its weak spot must have distressed him deeply." He takes advantage of the moment to impart his lesson, and "bending a stern eye upon [Rymer]," remarks, "To advocate socialism, as you do, is perhaps natural for a Protestant clergyman. It is good Christianity. But surely it is your duty to be critical and if necessary to denounce tendencies on the part of political extremists, to transform a basically Western theory into its illiberal opposite, substituting a violent caricature of the Hegelian State for the City of God"."43 He is speaking as one clerc to another, advising Rymer that just as a politics of the intellect is essential for the survival of intellect in the twentieth century, a politics of the spirit will be necessary also, if Christianity is to have any hope of surviving. The extent to which Lewis's lesson has penetrated Rymer is left ambiguous, as Rymer only remarks that " "no one can say ... . if I neglect to do my duty, that I did not know what it was." 944

Despite his concern over Rymer's politics, Lewis suggests that Rymer is in some respects already pointed towards the path away from the kulturkampf, and that in his embracing of poverty, which he displays unashamedly as a sign of his solidarity with the working classes, he contains "seeds of heroism." "45 Lewis envisions a future in which the clergy will be entirely deprived of money and social standing-a situation he feels will potentially strengthen and renew the faith. These clerics will live through charity, on the

\footnotetext{
${ }^{42}$ Ibid., 69.

${ }^{43}$ Ibid., 69-70.

${ }^{44}$ Ibid., 70.

${ }^{45}$ Ibid., 46.
} 
fringes of society, maintaining the faith in an age that has entirely rejected religion. Thus, Lewis sees Rymer's poverty as having a positive aspect, in that Rymer may serve as a model for this future clergy. He claims that "[Rymer] is not a throw-back to the religious mendicant, he is an advance copy (imperfect but authentic) of the hobo-holiness of Tomorrow. ${ }^{\$ 46}$ Later in the story, he clarifies this statement:

Soon all clergymen in this country will have vows of poverty thrust upon them as I have already suggested, and a new type of ministry will come into being. Quite probably it is the only way to secure a truly Christian Church. It may after all be God's will. In His great wisdom it would not be likely to escape Him that a penniless clergyman is better than one who rides to hounds. ... The clergy should prepare themselves for penury; else quite unprepared they will find themselves the poorest class of men. ... And they should accustom their parishioners to the idea that their sacred calling must reduce them to great poverty. ${ }^{47}$

Lewis implies that the first step that Rymer must take is to step outside the kulturkampf; he must become more critical of the socialism he espouses, or he will become one of its victims.

Lewis's approach to Laming is similar to his approach to Rymer, even though the politics of Laming and Rymer are antithetical. Laming's politics are as Rightist as Rymer's are Leftist; he is a follower of Thomas Aquinas and the natural-law tradition, is the author of a treatise on anti-usury economic theory, and is fighting a political battle against the government in defense of church-run schools. As with Rymer, Lewis uses a

\footnotetext{
${ }^{46}$ Ibid., 26.

${ }^{47}$ Ibid., 45.
} 
pseudo-Socratic method to reach an understanding of Laming's politics, simultaneously constructing a satirical portrait of Laming as a means of portraying him as a purveyor of a limited, partisan truth.

The extent of Lewis's sympathy for Laming is difficult to determine. At the beginning of the story, he bluntly remarks that "Matthew Laming is not unique, but he is one of a small number of country clergy attempting to stem the socialist tide. It is only worth while putting this episode on record because it demonstrates how futile any such resistance has become. ${ }^{» 48} \mathrm{He}$ adds that he, Lewis, is "ideally suited to report objectively this conflict between a centralizing Government and a dissident country clergyman." ${ }^{\circ 9}$ At the same time, however, he suggests that there are certain aspects of Laming's position that he finds admirable, although he is careful to qualify his praise. He continues, "On the other hand I admire this resister: and many of his beliefs I share. ${ }^{950}$ Lewis is particularly sympathetic towards Laming's anti-usury stance; however, he makes it clear that he is not an advocate of social credit, "only that the condition to which they persistently call attention appears at least as blood-curdling to me as it does to them." ${ }^{.51}$ Near the end of the story, Lewis's heavily-qualified sympathy for Laming is apparent when he comments, "it is for what [Laming] stands, in line with the natural law, that is interesting and respectable (I say respectable because I am not myself an advocate for the

\footnotetext{
${ }^{48}$ Ibid., 243.

${ }^{49}$ Ibid., 243.

${ }^{50}$ Ibid., 243.

${ }^{51}$ Ibid., 247. Lewis even provides an explanation of the concept of usury that echoes the tirades in his polemics of the 1930s: "The Banks and Insurance Companies, the coiners of false credit, the whole of the iniquitous Credit system, is what is involved-the chairman of your bank is an archusurer. And somewhere stands the Minotaur at the heart of the labyrinth." Lewis, Rotting Hill, 247.
} 
Past - though I should not be writing this were I an advocate for Progress either). ${ }^{92}$ Once again, Lewis is displaying a cautious sympathy for a brand of conservatism derived from Catholicism. He is willing to admire, but not necessarily to advocate, anti-usury economics and the natural-law philosophy of Thomas Aquinas.

Of course, this kind of qualified praise is typical of Lewis and part of a strategy to portray himself as a neutral third-party. He clarifies his position in a comment made shortly after referring to Laming as possessing the mind of a "rebounder":

I must here interpolate a reminder. There are of course other types of mind equally powerful, which rebound with equal violence: but in this case it is from the spectacle of the abuses flourishing in the systems to which [Henry Sumner] Maine and [Edmund] Burke gave their support. And I must add that there is, in my opinion, an even powerfuller type of mind which does not rebound in this manner at all. I refer to that order of mind which prefers not to see things in such stark black and white..$^{53}$

Rymer and Laming embody action and reaction respectively-they are essentially both "rebounders," in contrast to Lewis, who, presumably, possesses "an even powerfuller type of mind." Lewis, of course, also sees things in "black and white" in the initial stages of his process of cultural analysis; however, he sees dichotomies from the outside, and is able to subject them to a process of diremption, achieving a level of understanding that is unavailable to Rymer and Laming.

Lewis's interactions with Laming are much less intimate than those with Rymer,

\footnotetext{
${ }^{52}$ Lewis, Rotting Hill, 266.

${ }^{53}$ Ibid., 263.
} 
partly because Laming projects a far more austere persona and is hostile towards those who would question his values. ${ }^{54}$ Even Lewis's casual remark that he, Lewis, “"might become a socialist"" does not arouse a polemical response. ${ }^{55}$ Although Laming does not accept Lewis's message regarding the inevitability of socialism and the futility of reactionary resistance, Lewis feels that Laming's ultimate failure in defending the village school of Ketwood will inspire in him "some comprehension at last of the reality of village life in England in mid-twentieth century and some recognition not only of the power of the Welfare State, but of the absurdity of expecting anyone to back you up, except for an excited moment or two, in your defiance of authority. ${ }^{956}$ At that point, perhaps, Laming will finally realize that the kulturkampf cannot be won.

As in "The Bishop's Fool," Lewis's prescription for both Laming and the flagging Church is a strategic withdrawal from society. What he recommends is essentially the same sort of separation that he advocates for the clercs in The Art of Being Ruled. If Laming attempts to maintain his position of resistance within the kulturkampf, Lewis suggests, he will be overpowered by the state-his only hope is to venture to the "outside" and find a new vantage-point from which to promote Christianity:

Two world-wars in rapid succession have hurried the end of Christianity in England. Socialism, as time passes, melting into communism, will take religion's place in the form of a brotherly millennium-a heaven on earth for good socialist boys and girls, and a hell-on-earth for the wicked (vide slave-camps, salt-mines, etc.). In place of Christ there will be men-gods like Stalin or Hitler, a High God

\footnotetext{
${ }^{54}$ Ibid., 250, 256-257.

${ }^{55}$ Ibid., 262.

${ }^{56}$ Ibid., 270.
} 
being dispensed with. But that is taking the long view: it may be a decade before matters go as far as that. Meanwhile, it is difficult to see how Christianity can live, if only for a moment, except by some heroic measure. One that recommends itself to me, is that all the churches, vicarages, bishops' palaces, etc., be closed. The clergy would then become a missionary army, as friars, I suppose: poor but impassioned men, tramping from village to village, and filling the cities with their prayers and curses. ${ }^{57}$

It is unclear if Lewis believes that the "missionary army" of the clergy will be able to function in the new communist millennium, or if they too will become, despite their withdrawal from society, among the "wicked" destined for the slave camps. Regardless, Lewis is essentially calling for a return to the roots of the Christian faith-a separation of the originary ethic of unworldliness from the Christian-humanitarian impulse that he felt was threatening to become autonomous, or removed from the idea of God, through the establishment of a socialist world-state.

In both "The Bishop's Fool" and "Parents and Horses"-and in his last novel, The Red Priest (1956)-Lewis displays an interest in the priesthood that reinforces the parallels between clerics and intellectuals. In analyzing Rymer and Laming, and in speculating regarding the fate of their calling, Lewis is also indirectly speculating upon the fate of the intellectual. Rymer and Laming are each, to some extent, guilty of engaging in the treason of the clercs, in that they have become involved in partisan politics. It is his hope that they, like him, may find their way to the "outside light" and free themselves from the kulturkampf. By contrast, in "Time the Tiger," Mark and

\footnotetext{
${ }^{57}$ Ibid., 273.
} 
Charles are portrayed as being doomed to carry out their roles in the kulturkampf. They do not fit the mold of Benda's clerkly caste-or those who, according to Benda, say, "My kingdom is not of this world." $" 58$

Despite Lewis's apparent sympathy for the middle-class masses, his evangelical impulse, in practice, is directed at a select few, and certainly does not extend beyond his interactions with the middle class. Throughout Rotting Hill, he displays an attitude of extreme condescension towards the working class, whom he characterizes as possessing no intellectual complexity whatsoever. In his introduction, he dismisses the working class entirely, remarking that "the toiling majority naturally do not discuss 'Welfare States,' merely respond vocally to the pleasant or unpleasant stimuli for which the 'high-ups' of whatever political philosophy are responsible." 59

The only extended conversation that Lewis has with a person of this class occurs in the story "My Fellow Traveller to Oxford." Lewis describes a train trip in which he meets a mature Oxford undergraduate named Ronald, who is a "fellow-traveller" in a number of respects. Aside from being Lewis's temporary travel-partner, he has been given a government-sponsored opportunity to study at Oxford and travel in circles outside his social class; he is also, as Lewis quickly discovers, a fanatical communist sympathizer-a "fellow-traveller" with Moscow. Lewis bluntly remarks that "he [Ronald] never left one in doubt as to his feelings about anything, and they were invariably strong and intensely disagreeable. ${ }^{" 60} \mathrm{He}$ is, in Lewis's eyes, a brutish representative of a New World Order, so thoroughly politicized that he is incapable of critical thought.

\footnotetext{
${ }^{58}$ Benda, The Treason of the Intellectuals, 43.

${ }^{59}$ Lewis, Rotting Hill, 11.

${ }^{60}$ Ibid., 85.
} 
His encounter with Ronald comes as he is in the midst of reading Jacques Maritain's introduction to Human Rights, a UNESCO-sponsored collection of texts on the subject of the 1948 Universal Declaration of Human Rights. Using a perverse conversational tactic that he knows will fail, Lewis attempts to explain to Ronald the difference between traditional Western political rights and the new economic and social rights as they are discerned in the UNESCO book. His argument is that new economic and social rights must not be established at the expense of traditional political rights, but this important qualification is lost on Ronald. Lewis remarks that during his explanation, "The dialectical torrent was seething behind his [Ronald's] dental plate."61 This "dialectical torrent" that inhabits Ronald is the historical force of the aforementioned "violent caricature of the Hegelian State." Ronald is more than willing to sell his freedom for a new dental plate, and enthusiastically anticipates a future totalitarian society. With regard to his ideological homeland, communist Russia, Ronald remarks, "'It is a totally new civilization - a Russian communist's nervous system, his entire cerebration, is upon a different plane to that of a Western democrat. It is impossible to compare, even, Western and Soviet ways of feeling—-they are unrelated upon any level." ${ }^{\prime, 62}$ This antagonism towards the liberal-democratic spirit of compromise is encapsulated in a single statement: "II wish to be an integral social being." ${ }^{963}$ For Ronald, liberalism violates social integrity. He is a fully-realized example of the species of human that Lewis suggests is gestating inside Rymer and into which Mark is eventually transformed; thus, he is a true representative of the New, or what Lewis describes as "a walking idea

\footnotetext{
${ }^{61}$ Ibid., 89.

${ }^{62}$ Ibid., 90 .

${ }^{63}$ Ibid., 91 .
} 
with which one has to come to terms — or the earth will blow up. ${ }^{964}$

Lewis appears at least superficially resigned to the idea that the future belongs to Ronald. The members of the middle class, mired in a domesticated, outdated political battle that serves only to erode social cohesion, are in a sense inferior to Ronald, whose valuing of social collectivism is more reflective of global trends. Ultimately, Lewis sees two likely alternatives for the future of mankind: a Third World War between a liberal and an anti-liberal socialism, or the triumph of an absolutist socialism and the creation of a world-society of "Ronalds." Ronald's extreme politicization is the prelude to a world without philosophy, politics, or true art-a world of "integral social beings" living in totalitarian bliss.

Lewis's vision of the future in Rotting Hill is bleak, but his attempts to rescue a potential new priesthood from the kulturkampf suggest that underneath this political pessimism lies the possibility of a form of individual resistance through intellectual nonpartisanship and a refusal to distinguish between friend and enemy in absolute terms. The type of detachment that Lewis advocates, however problematic it may potentially be in other respects, allows for an understanding of the political whole, which Lewis suggests is perhaps the only means of preserving both the spirit and the intellect in the age to come. The study of kulturkampf rhetoric, then, can provide the intellectual with material for a properly dialectical attempt to understand the political.

Like Laming defending his tiny church-run school before the monolithic welfare state, Lewis quixotically places his ideal of humble detachment in opposition to a worldhistorical Hegelian-Marxist dialectic. At one point in their discussion, Rymer asks Lewis

\footnotetext{
${ }^{64}$ Ibid., 86.
} 
what action he plans on taking if he is so dissatisfied with the current state of socialism.

Lewis responds, "I neither wish, nor should I be able, of course, to take any action." "65 This type of political apathy sounds just as alien in our current cultural climate as it would have in the England of the Attlee era, but the Rotting Hill stories, taken as a whole, suggest there is perhaps something reasonable, if not noble, in such a response.

${ }^{65}$ Ibid., 70 . 


\section{Chapter Five}

Signs of God: The Failure of the "Politics of the Intellect" in Monstre Gai and Malign Fiesta

If Lewis's re-examination of the kulturkampf in Rotting Hill suggests a cautious return to his politics of the 1920s and 30s (as seen from the perspective of the atomic age), that phase was short-lived; a few years before his death, Lewis radically revised his perspective on politics, partly as a result of his increasing interest in the Catholic faith he had strategically supported at various times throughout his career. Lewis's unfinished tetralogy The Human Age, which consists of The Childermass (1928), Monstre Gai (1955), Malign Fiesta (1955), and the projected The Trial of Man, stands as one of the most ambitious modernist explorations of the Christian religion, and as a total revaluation of the problem of the relationship between the artist-intellectual and the kulturkampf. Lewis's protagonist in these novels, James Pullman, is a deceased literary celebrity who finds himself traveling through the afterlife with his dim-witted friend Satters-first to a limbo-like camp outside the gates of what appears to be Heaven, then to the purgatorial welfare-state of Third City, and finally to the brutal prison-state of Matapolis or Hell. Through a flawed decision-making process, Pullman allows himself to enter into temporary political alliances with two extraordinary figures: the Bailiff of Third City and Sammael (or Satan), the ruler of Matapolis. Eventually, Pullman becomes Sammael's reluctant aide, guiding him in his ill-fated quest to interbreed angels and humans and create a new Human Age.

In Monstre Gai and Malign Fiesta, Lewis's politics of the intellect are put to the test in a new context, and Pullman reveals their paradoxically unintellectual mechanisms 
through his behaviour. Despite considering himself a defender of the intellect and a "'lone wolf' man, of the fierce modern 'genius' type,"1 Pullman is unthinkingly drawn towards what I refer to as "signs of the intellect," or tangible manifestations of human reason, in his efforts to navigate the otherworldly kulturkampf. This deeply-rooted habit, which had served him well on earth, eventually proves destructive in the afterlife, and gives way to what can only be described as the beginnings of a conversion experience, in which he realizes he has been ignoring what I refer to as "signs of God," or tangible manifestations of God's power. Eventually, he recognizes that in his attempt to protect the intellect, he has fallen into sin. At the end of Malign Fiesta, he is at last confronted by an unequivocal "sign of God" in the form of a letter delivered by a heavenly angel: "Prepare for the punishment you have called down upon yourself, follower of the Evil One."2 In The Human Age, then, for the first time in Lewis's fiction, the intellect becomes the betrayer of man.

Over the course of Monstre Gai and Malign Fiesta, the politics of the afterworld reveal their own ephemerality as the friend/enemy divide of the political is replaced by a moral divide between good and evil, or God and Satan. Lewis had shown in his earlier work that it was possible for the intellect to preserve itself in the realm of the political, but the demand for moral commitment on the part of God proves to be an insuperable obstacle to Pullman, and his strategies fail entirely. Eventually, Pullman realizes that in order to save his soul, he must release his grip on the intellect; instead, he must follow

\footnotetext{
${ }^{1}$ Lewis, Monstre Gai, 173.

${ }^{2}$ Lewis, Malign Fiesta, 545.
} 
the advice of Jesus Christ, and become like a child in order to enter the Kingdom of Heaven. ${ }^{3}$

Given the parallels that exist between Lewis and Pullman, The Human Age documents not only a transformation in its main character but also in its implied author; Pullman's descent into sin brings into relief a radical shift in Lewis's thinking that has not been fully explored in Lewis criticism. ${ }^{4}$ Lewis spent most of his career constructing a cultural philosophy that positioned the intellectual as an outsider relatively immune to the partisan political battles of the rest of humanity. In The Human Age, however, Lewis becomes the observer of a crisis in his own thought, brought about by a serious consideration of the tenets of Christianity, and of Roman Catholicism in particular. Instead of presenting himself as a seeker of converts to his brand of heterodoxy, Lewis suggests he has become a potential convert to an orthodoxy he once resisted. Over the course of Pullman's decline, the stark Lewisian opposition between the intellectual and society is replaced by a conflict between two related but ultimately conflicting ways of life: a life devoted to the intellect and a life devoted to God. The problem of choosing the right path in this regard was of intense personal significance to Lewis, I propose, as he reevaluated his life in light of the real possibility of facing Divine judgement after death, prompted by his old age, serious health problems, regret over personal and professional

\footnotetext{
${ }^{3} \mathrm{Mk} 10: 15$.

${ }^{4}$ The best studies of the last two finished novels of The Human Age include Hugh Kenner's "The Devil and Mr. Lewis" and discussions of the novels in Paul Edwards' Wyndham Lewis: Painter and Writer, Daniel Schenker's Wyndham Lewis: Religion and Modernism, and Brian James Murray's PhD dissertation, “Awaiting the Apocalypse: The Later Novels and Short Stories of Percy Wyndham Lewis." Edwards, 528-549; Schenker, 168-184; Murray, 147-160. Peter L. Caracciolo has also done some intriguing research into the sources, literary and otherwise, that Lewis used for The Human Age. See, for example, "The Metamorphoses of Wyndham Lewis's The Human Age: Medium, Intertextuality, Genre," and "From Signorelli to Caligari: Allusions to Painting and Film in The Human Age and its Visual Precursors."
} 
mistakes, and his exposure to orthodox Catholic thought during his association with Assumption College in Windsor, Ontario from 1943-44. The Human Age can thus be read not only as an allegorical satire, but as a private vision of the afterworld in which Lewis, both as implied author and through the character of Pullman, finds himself witness to a cosmic battle in which he has sided with the losing team. Thus, The Human Age may be accurately called a revelation or an apocalypse. Furthermore, it implicitly functions as something entirely foreign to the rest of Lewis's work: an endorsement of the absolute and a call to partisan action on behalf of God.

James Pullman, in The Human Age if not in the earlier Childermass, is a consummate clerc. His clerkly credentials become obvious as the story progresses: the narrator eventually reveals that Pullman was a famous and prolific author whose highbrow, sometimes experimental works included satires and writings on the Patristic Age. ${ }^{5}$ His idea of paradise is manifested in the room prepared for him in the Phanuel Hotel by the Bailiff, which is stocked with "hundreds of books, from Lautréamont to Lucretius." Upon seeing it for the first time, he declares, "“This, beyond a shadow of a peradventure, is Heaven." "'7 A question, however, that Lewis implicitly asks throughout The Human Age is whether, in the context of the afterworld, Pullman is a good clerc and a faithful practitioner of the politics of the intellect. Both Hugh Kenner and Paul Edwards suggest that Pullman ultimately commits what amounts to intellectual treason in his alliance with Sammael. ${ }^{8}$ Munton sees the Pullman of The Childermass as a bad

\footnotetext{
${ }^{5}$ Lewis; Monstre Gai, 235, 173; Malign Fiesta, 343; Monstre Gai, 125.

${ }^{6}$ Monstre Gai, 172.

7 Ibid., 172.

${ }^{8}$ Kenner, "The Devil and Mr. Lewis," 29; Edwards, Wyndham Lewis: Painter and Writer, 541.
} 
intellectual, but states that the opposite is true in the later books: "Sympathy for Pullman, and the willingness to make God's forgiveness of him part of his subject had to wait until Lewis belatedly realized that the intellectual who is hypercritically alert to the ideological pressures submitted to by other writers may himself be taken in, all the while believing that his superior theoretical equipment makes him invulnerable." ${ }^{\text {M }}$ Munton does not expand upon this assertion in any detail, but his thesis is more convincing than that of Kenner and Edwards. It is my contention that Pullman proves himself to be an exceptionally adept practitioner of "the politics of the intellect," to the extent that he becomes a parody of the Lewisian intellectual. In fact, it is precisely his intellectual virtuousness that leads him into sin and muddies his understanding of the true nature of the afterworld.

The kulturkampf that Pullman encounters in Third City bears a strong resemblance to that of Europe in the twentieth century; the insidious politics of Earth, Pullman discovers, have infiltrated the afterlife. The Bailiff and his followers are the representatives of the New, and act according to a confusing mishmash of liberal and left-wing ideology. The Catholics, led (it appears) by Monsignor O'Shea, represent the Old. The militant offspring of these two poles of the kulturkampf are present as well. The Hyperideans, led by the charismatic Hyperides, represent fascism, and there also exists a corresponding communist movement, represented by a man named Vogel. Pullman's position in relation to these movements is dramatized in the great debate that occurs in the Piazza of Third City. Pullman finds himself in a crowd amidst two groups of two

\footnotetext{
${ }^{9}$ Munton, "A Reading of The Childermass," 132.
} 
parties, positioned on opposite ends of the Piazza. Hyperides occupies a pulpit close to the rostrum of the Catholics (who are represented by the speaker Father Ryan). ${ }^{10}$ On the other side of the Piazza, the Bailiff occupies a stage that is guarded by his supporters and those of the communist Vogel. Two political dichotomies are here united: the Old versus the New, and the fascist Right versus the communist Left. Each side is poised to unleash violence upon the other, and to fulfill the always-present potential for violent conflict inherent to the Schmittean conception of the political.

Pullman realizes he must choose his allies carefully, but for anyone familiar with Lewis's work, his decision-making process is entirely predictable. He is consistently drawn towards what I have referred to as signs of the intellect, even when alternate paths are open to him. Like the pre-Human Age Lewis, Pullman sees any form of orthodoxy as being detrimental to the health of the intellect. Orthodoxy, once established, obliterates critical intelligence, which is inherently unstable and heterodox. Pullman's recoil from the trappings of orthodoxy accounts, at least in part, for his unwillingness to submit to the angelic Padishah of Third City. His decision is based upon his evaluation of Angels as being essentially unintellectual, in that because they act according to principles that are eternal and absolute, they have no need for critical intelligence. Pullman says to his Third City compatriot Mannock, “I will admit that only what is intelligent really interests me. Perfection repels me: it is (it must be) so colossally stupid. Here-in Third City-we are frail, puny, short-lived, ridiculous, but we are superior, preferable to the Immortals with whom we come in contact.""11 The Bailiff is certainly not perfect, and is even, it is later

\footnotetext{
${ }^{10}$ Lewis, Monstre Gai, 255.

${ }^{11}$ Ibid., 165.
} 
revealed, part human; thus, he is more in touch with the human world, and with the human intellect.

Pullman's disastrous decision to ally himself with the Bailiff rather than the Padishah or Monsignor O'Shea is also reflected in the title of Monstre Gai, which is a fragment from a quotation attributed to Voltaire by Nietzsche in The Will to Power: "A gay monster is better than a sentimental bore."12 If the Bailiff is a "gay monster," as he is called by the narrator, ${ }^{13}$ then the Padishah is presumably a "sentimental bore." The Bailiff, despite his tendency towards vice and deception, is able to provide Pullman with intellectual stimulation, not only through his gift of the room at the Phanuel Hotel, but through the generally sophisticated company he keeps. The extravagant party that Pullman attends at the Bailiff's palace is host to a cosmopolitan crowd of otherworldly figures; the decor-which Pullman's companion Sentoryen describes as possessing an "exquisite frigidity"-and the music-consisting, at least in part, of the 12-tone composer Alban Berg's Lyric Suite-submerge the party in an austere modernist aesthetic. ${ }^{14}$ The Bailiff himself projects an attitude of wild heterogeneity, especially in contrast to the Padishah, who stoically submits to God's will. Whereas the former represents intellectual heterodoxy, the latter represents a stifling orthodoxy.

Pullman's aversion towards the unintellectual is, paradoxically, an unintellectual or habitual trait-a form of orthodoxy in itself. In his earthly life, Pullman trained himself to recognize and follow signs of the intellect. In doing so, he entered the company of

\footnotetext{
${ }^{12}$ Nietzsche, The Will to Power, 56.

${ }^{13}$ Monstre Gai, 284.

${ }^{14}$ Ibid., 126.
} 
those with a stake in protecting people like himself-particularly the political Left. ${ }^{15}$ As a result, his politics of the intellect are honed to such a point that they are almost indistinguishable from the degraded Machiavellianism that Lewis frequently denounced as the characteristic trait of the anti-intellectual "man of the world" or Everyman. Like a creature that only registers perceptually what is helpful or harmful to it, Pullman constructs his semiotic reality according to an instinct of intellectual self-preservation. During his stay in Third City, for example, he almost completely ignores, except in isolated moments, the possibility of an alliance with the Catholic majority-something that would have been easily within his grasp, for although Pullman is agnostic, he was raised Catholic and educated by Jesuits. ${ }^{16}$ Catholicism, for Pullman, represents orthodoxy, and even worse, a return to a state of existence that he associates with childhood. Joining the Catholic majority would be an intelligent strategic decision on both practical and spiritual levels, due to their numbers and their close attachment to God, but not one that would allow his intellect to continue to function unfettered. Instead, Pullman sides with the Bailiff, whose Leftist politics, constantly shifting persona, and unclear religious affiliations offer a more appealing environment for the heterodox critical intelligence.

There are a number of pivotal moments in Pullman's journey when his semiotic reality, structured to serve the intellect, is temporarily disrupted. In these moments, Pullman becomes aware of what I refer to as "signs of God," or signs of the reality of the Christian God and all its implications, and is offered glimpses behind the facade of the

\footnotetext{
${ }^{15}$ Ibid., 173.

${ }^{16}$ Ibid., 99.
} 
modernized afterlife. An early sign of God appears at the beginning of Monstre Gai when Pullman and Satters first enter Third City. They witness a parade staged by the Bailiff's militia, and Pullman takes special notice of the Bailiff's pennon, or personal banner, which is being carried in advance of his litter, or wheelless carriage. The symbols on the pennon include an Orphic egg and snake, the outline of a fish representing Jesus Christ, and the number 666. Significantly, Pullman is able to identify only the most obscure symbol. The narrator describes Pullman's thoughts: "The Serpent's head in conjunction with the Egg presented no difficulty, but the significance of 666 , though it had a familiar sound, baffled him. He paused a moment, his eyes fixed upon the mysterious number, when he became conscious of someone behind the curtains of the litter. Not without some slight misgiving he realized that the Bailiff was within, the curtains drawn."17 Pullman ignores the fish symbol, but politely asks the Bailiff to explain the meaning of the number 666 , and the Bailiff evades his question, saying, "I have a note of that somewhere. Come and see me at my residence'," and quickly changes the subject. Pullman fails to recognize 666 as the number of the Beast from the Book of Revelation because it does not conform to his semiotic reality in that it is associated with the repressed Catholicism of his youth, while the far more obscure symbolism of the Orphic egg, with its associations with Gnostic heresy and esotericism, attracts his attention as a heterodox intellectual. As a result, he fails to recognize the Bailiff as an anti-Christ figure.

\footnotetext{
${ }^{17}$ Ibid., 9-10.
} 
Later, at a party at the Bailiff's palace, another sign of God appears while the Bailiff is trying to convince Pullman that the traditional idea of Hell is merely superstition, and that it is a perfectly respectable place. They are interrupted by a lone dissenter, who shouts " That is a lie. I have been there-I know what it is like. And it is not like that! What he has been saying is a pack of lies. Satan . . Satan was expelled from Heaven. He . . '”"18 The dissenter is silenced by the bludgeons of the Bailiff's guards and taken away for interrogation; the Bailiff, meanwhile, continues his discourse on the modern Hell and the "liberalized" Lucifer, and Pullman quickly forgets about the temporary disruption. ${ }^{19}$

This pattern, consisting of the intrusion of a sign of God followed by its quick erasure from Pullman's consciousness, functions as a recurring motif in The Human Age. As Pullman's journey progresses, the signs of God become more intrusive and disturbing, with Pullman's response typically consisting of a moment of uncontrolled emotional turmoil followed by the defensive mechanism of the rationalization and intellectualization of the sign. Over the course of Monstre Gai and Malign Fiesta, Pullman is exposed to images of supernatural splendour and terror that force him to cling ever more tightly to the comforting detachment that the intellectualist worldview provides. The most disturbing representations of divine justice appear in Malign Fiesta, when the Mengele-like Dr. Hachilah takes Pullman on a tour of the punishment centre of Dis. During the tour, Pullman struggles to maintain his intellectual detachment, knowing

\footnotetext{
${ }^{18}$ Ibid., 133.

${ }^{19}$ Ibid., 135. The Bailiff states that "'Lucifer and his subjects are tremendously 'liberalized,' as it is called."
} 
that showing fear would represent an insult to the intellect and jeopardize his standing with Sammael. His efforts to restrain his fear and outrage are reflective of Lewis's doctrine of moral neutrality, but they blur the distinction between anti-humanist intellectualism and inhuman coldness. Shortly after seeing a cavalcade of grotesque Danteesque punishments-in-progress, the fatal stabbing of a female Dis doctor, and the spectacle of a German general being burned alive for his wartime sins, Pullman allows himself to break down temporarily in front of Hachilah. Rather than regarding Pullman's fit of anxiety as a sign of Pullman's weakness, Hachilah expresses amazement that the punishment centre did not exert a stronger emotional effect, remarking, "My dear fellow .... You saw a murder and an execution without turning a hair!" ${ }^{20}$ At this point in his journey, Pullman's options regarding his continued existence in the afterlife have become restricted; unable to join willingly the forces of evil, he can either rebel against Sammael, which would likely result in punishment in Dis, or carry on relying on his anti-humanist intellectualism until he becomes like Hachilah.

Pullman's choices in his alliances hinge upon his devotion to the intellect; thus, two of the most direct and penetrating signs of God are revealed to Pullman in the form of verbal accusations that acknowledge his intelligence but also invoke moral standards of intellectual responsibility that blur the sharp Lewisian distinction between the intellectual and the moral. When the fascistic Hyperideans interrogate Pullman at their headquarters, his first accuser, Michael Devlin, confronts him. Devlin knows of Pullman's former life as an intellectual and berates him for associating with the Bailiff,

\footnotetext{
${ }^{20}$ Lewis, Malign Fiesta, 423.
} 
saying, "You are consorting with the scum of the earth, and you know what you are doing. To save your own skin you accept help from an inhuman beast in the form of a man. .. . You are a rat-yes, a far worse rat because you are an intelligent rat."

In Malign Fiesta, Pullman encounters another accuser when Sammael takes him on a car ride to the valley outside Matapolis. Sammael intends to dispose of a female sinner in the valley, which is populated by wild demons, but before he throws the woman from the car, she launches into an invective against Pullman, which, like that of Devlin, addresses Pullman's status as an intellectual:

"As for you, sir, you have that little smile of yours because you are afraid. Yes, yes. You are afraid of this terrible monster who takes human form but is none the less terrifying for that. But you are intelligent, you see what is underneath. You see the terrifying monster-you are not deceived by the face like that of a man. Ah yes, like myself, you are human, you have reason to tremble-what else could you do but smile scornfully to order! You do not want to be in my shoes, my poor little fellow. The implacable merde you divine, the merciless excrement which serves him for blood!"22

The female sinner sees Pullman's "little smile" for what it is: a false front of detached civility masking his guilt. On some level, as his accuser suggests, Pullman is quite aware that Lucifer is not the liberal and sophisticated gentleman he pretends to be, and that the ancient view of Lucifer as the source of all evil is not merely a "superstition," as the

\footnotetext{
${ }^{21}$ Lewis, Monstre Gai, 221.

${ }^{22}$ Lewis, Malign Fiesta, 371.
} 
Bailiff asserts. ${ }^{23}$ What both of these accusers imply is that Pullman's intelligence and his capacity for critical reflection make him not less but more morally culpable.

Shortly after the episode in the valley, a formal accusation-and seemingly undeniable sign of God-arrives in the form of the aforementioned letter of official disapproval from Heaven, which does not, however, succeed in altering Pullman's course. A second letter from Heaven soon arrives, when Pullman is staying at the Haus Europa residence for intellectuals, and its tone is no less compromising:

"On earth, gifted with cleverness, you were full of wickedness. You died, Pullman, as you had lived, without seeking the mediation of a priest. You believe that you can reproduce upon the plane of eternal life your life on Earth. But you will meet with your fate before the sun sets-prepare to be expelled from the socalled Haus Europa, and to find yourself in eternal damnation." ${ }^{24}$

Even when faced with this seemingly uncompromising declaration, Pullman is still unwilling to acknowledge fully his sins and repent, and takes comfort in the fact that this sign of God, however direct it might be, is still merely a sign. Because God Himself has not signed it, there appears to be no direct connection between the signifier (the letter) and the signified (God's final judgement). Pullman asks the angel who has delivered it if the message is from God Himself, to which the angel replies, “"He for whom I act interprets the mighty thoughts of Another, about whom you speak." ${ }^{25}$ Thus, the message is twice removed from the mind of God: it was delivered by an underling of someone

\footnotetext{
${ }^{23}$ Lewis, Monstre Gai, 294.

${ }^{24}$ Lewis, Malign Fiesta, 555-6.

${ }^{25}$ Ibid., 555.
} 
who "interprets" God's thoughts. The narrator describes Pullman's thoughts in the aftermath of the messenger-angel's visit:

He began turning over in his mind what the angel had said. The message had been composed by some inferior, or at least not by God. This, oddly enough, supplied him with the wherewithal for hope. How his mind worked was to attribute great importance to the statement It was not God. The writing on the wall had not the signature of God. It was not a first-class document. Would God have okayed it? He must get an appeal through to God in person. ${ }^{26}$

As the narrator notes, finding a loophole in what appears to be a final judgement is "How his [Pullman's] mind worked." Even at this stage of his descent into sin, Pullman must intellectualize his position in relation to God and postpone the repentance that could save him. Without seeing God face-to-face, he cannot accept fully a moral framework that posits the existence of good and evil and demands moral responsibility on the part of humans.

Despite the resistance he puts up, in many of Pullman's confrontations with the signs of God, his repressed Catholicism temporarily rises to the surface. Early on in Pullman's journey, the narrator remarks, "Solipsistic he was in principle, but no man is so watertightly an ego as all that. He had started life a devout Catholic, for instance: and that first self haunted him to some extent."27 The signs of God shake Pullman's worldly confidence and trigger the temporary emergence of his "first self," causing him to turn instinctively to the religion of his youth. One such moment occurs shortly after the forces

\footnotetext{
${ }^{26}$ Ibid., 556.

${ }^{27}$ Lewis, Monstre Gai, 173.
} 
of Hell launch a preliminary attack on Third City. A group of demon diplomats arrives from Hell and is greeted by the Padishah's angels. A battle ensues in which the angels and demons assume gargantuan size and Pullman realizes that he is seeing a clear manifestation of the supernatural. Momentarily stunned, he mutters, "Almost thou persuadest me to be a Christian',"28 the words that King Agrippa says to Paul in Acts 26:28 of the King James Version of the Bible. He tells his friend Mannock that he must find a Catholic priest in order to confess his sins, but when the demons disappear in a cloud of noxious smoke, the ensuing confusion forces him to retreat to Mannock's residence, and his sudden urge for confession is forgotten.

These sporadic eruptions of a repressed Catholicism continue as Pullman's journey progresses and the signs of God continue to intrude; once Pullman reaches Matapolis and meets Sammael, and the falsity of the Bailiff's description of Hell becomes apparent, Pullman finds himself beginning to pray, attempting secret communication with God. In his prayers he acknowledges some of his sins, and notes that Satters "had in no way shared in his sinfulness, indeed he was so simple that he was incapable of $\sin . " 29$ When confronted by the stark brutality of the punishment of sinners in Hell, his inner conflict is further intensified, and he finds it remarkable that he is beginning to take the religious attitude seriously. For guidance he has turned to what he formerly associated with the naive worldview of the child, and what he believed to be mere "superstition,"30 namely the traditional Catholic conception of man's relationship

\footnotetext{
${ }^{28}$ Ibid., 112.

${ }^{29}$ Lewis, Malign Fiesta, 351.

${ }^{30}$ Ibid., 457.
} 
with God. The narrator remarks of Pullman, "These childish conflicts (as on Earth they would be called) were very real for this unfortunate man, severed from mankind, torn away from his earthly life, and finding himself in a nightmarish existence, where the supernatural was the real, and where he had had to go back to his childhood to deal with a death-life full of traps. ${ }^{931}$ The politics of the intellect are useless in Lucifer's territory; sophisticated evil, Pullman comes to learn, can only be fought with the child-like trust in God advocated by Christ.

Eventually, from his vantage point in Matapolis, Pullman is able to look back upon the various signs that marked his passage into a recognition of the supernatural and the split in his personality it created:

It had, in the first place, been because of a sparrow, then of a live angel (the Padishah), and then because of a delegation from Hell-whose stench was still in his nostrils-and so on, and so forth, that he had reviewed his earthly scepticism, and here he was, praying on the one hand as if he were back in childhood, and paying court to the devil on the other. A double and contradictory manœuvre. ${ }^{32}$ It is interesting that at this late stage in his journey, Pullman remembers the seemingly insignificant sign consisting of the sparrow that delivered his invitation to meet the Padishah. In the Christian tradition, the sparrow symbolizes God's love for all creatures, no matter how insignificant they may be..$^{33}$ If Pullman had been able to understand the

\footnotetext{
${ }^{31}$ Ibid., 457.

${ }^{32}$ Ibid., 458 .

${ }^{33}$ In the Gospel of Matthew, when instructing his disciples, Jesus remarks, "CCan you not buy two sparrows for a penny? And yet not one falls to the ground without your Father knowing. Why, every hair on your head has been counted. So there is no need to be afraid; you are worth more than many sparrows." Mt. 10:29-31. The Holy Bible: The New Jerusalem Bible, 1159.
} 
symbolism behind the sparrow-which should have been possible given his Catholic upbringing-he would perhaps have altered his stance towards the Padishah. Submitting to the Padishah and surrendering his intellect to Christian orthodoxy would not have lowered his status in the eyes of God, who values even the lowly sparrow. Instead, Pullman is swayed by both his intellectual pretensions and by the Bailiff's mocking attitude toward the Padishah's sparrow-signals, ${ }^{34}$ and it is only after finally submitting to Sammael that he comes to the realization that "God values man." 35

Despite being seemingly ineffectual, the signs of God have a subtle transforming power, and the afterworld, as perceived by Pullman, becomes increasingly a liminal space, or a constantly fluctuating battleground between the human intellect and the Divine Intellect. The liminality engendered by Pullman's transformative episodes affects both the reader's understanding of Pullman's character and the form and genre of the text as a whole. Lewis's drama of the afterworld is not only a satirical commentary on earthly life that incorporates apocalyptic and Danteesque imagery, but also a vision of the afterworld and a prophecy regarding how history will end-in other words, an authentic modernist apocalypse. ${ }^{36}$ Over the course of the trilogy, the picaresque aimlessness of satirical narrative (so integral to Lewis's earlier novels) gives way to a linear apocalyptic narrative involving the rise of the anti-Christ, a war between a clearly delineated Heaven and Hell, and finally, the Last Judgement (as is suggested by the title of the projected fourth book, The Trial of Man).

\footnotetext{
${ }^{34}$ Lewis, Monstre Gai, 137-148.

${ }^{35}$ Lewis, Malign Fiesta, 528.

${ }^{36}$ Daniel Schenker, in Wyndham Lewis: Religion and Modernism, describes The Childermass as a "modernist apocalypse," but his study of the novel does not directly address Lewis's apocalypticism.
} 
Peter L. Caracciolo argues that Lewis's allusions in The Human Age to the apocalyptic art of Luca Signorelli, along with Sammael's references to the Anti-Christ, suggest that The Human Age is meant to at least have apocalyptic overtones. ${ }^{37}$ Certainly, allusions to apocalypticism, and not just to the canonical Book of Revelation, abound in the work. A more obscure allusion occurs when the narrator describes Pullman's thoughts regarding the environment of Third City: "He felt that he had been rapt into some bursting dream of the Apocalypse of Baruch or of the Secrets of Enoch, he must avoid becoming engulfed, he must secure a foothold, however tenuous." ${ }^{, 38}$ Both of the works that Pullman mentions are considered part of the Old Testament Pseudepigrapha. Presumably, by "the Apocalypse of Baruch," Lewis means the Greek Apocalypse of Baruch or 3 Baruch, as this is the only one of the Baruch texts in which Satan is referred to as Sammael, as he is referred to throughout most of The Human Age. The Book of the Secrets of Enoch, also known as the Slavonic Enoch or 2 Enoch, is an apocalyptic text as well, which describes the otherworldly journeys of Enoch, who is taken on a tour of heaven by two angels. In the fifth heaven, Enoch sees the Grigori, or angels who, long ago, were led into rebellion against God by their leader Satanail (another name for Satan that also appears in The Human Age,${ }^{39}$ and who bred with human women, producing a race of giants. This story is recounted near the end of The Human Age where Pullman learns that the Bailiff and many of the residents of Matapolis are "Nephalim [sic]," or

\footnotetext{
${ }^{37}$ Caracciolo, "From Signorelli to Caligari: Allusions to Painting and Film in The Human Age and its Visual Precursors," 144.

${ }^{38}$ Lewis, Monstre Gai, 157.

${ }^{39}$ In the text, it is spelled "Satanael" rather than "Satanail," but it appears to be the same name.

Lewis, Malign Fiesta, 337.
} 
part-divine/part-human descendants of these original giants. ${ }^{40}$ The references to 3 Baruch and 2 Enoch show that Lewis drew upon at least three apocalyptic literary works (including the Book of Revelation) when writing The Human Age. ${ }^{41}$

Generically, The Human Age fits the apocalyptic mold. One of the standard definitions of apocalyptic literature comes, as John J. Collins notes, from a 1979 issue of the journal Semeia. The definition reads as follows: "[an apocalypse is] a genre of revelatory literature with a narrative framework, in which a revelation is mediated by an otherworldly being to a human recipient, disclosing a transcendent reality which is both temporal, insofar as it envisages eschatological salvation, and spatial insofar as it involves another, supernatural world." ${ }^{.42}$ In The Human Age, Pullman, of course, is the "human recipient." The Bailiff is the central "otherworldly being" in Monstre Gai, while Sammael plays this role in Malign Fiesta. Furthermore, The Human Age may certainly be read as a dream or revelation of Pullman; the elusive, constantly shifting nature of the Bailiff, for example, suggests a dream-like fluidity.

Apocalyptic texts usually purport to represent a description of a vision experienced by the author. Thus, to read The Human Age as an apocalypse demands an evaluation of Lewis's relationship to the text as implied author. Lewis's use of third-

\footnotetext{
${ }^{40}$ Lewis, Malign Fiesta, 335.

${ }^{41}$ In situating The Human Age within the realm of apocalyptic literature, I am implicitly critiquing Michael Nath's argument that the theological foundations of The Human Age are in the writings of the ancient Gnostics. Gnosticism, with its emphasis on the acquisition of knowledge, is at least superficially compatible with Lewis's championing of the intellect, but there are no explicit references to Gnosticism in The Human Age. Nath sees the Bailiff's mother's references to the Nephilim as being derived from both Genesis 6 and the Gnostic The Apocryphon of John, but it is more likely that Lewis derived it from Genesis 6 and 2 Baruch, given that Lewis explicitly mentions 2 Baruch in the text. Nath, "'Monstrous Starlight': Wyndham Lewis and Gnosticism," $162-163$.

${ }^{42}$ Qtd. in Collins, The Apocalyptic Imagination, 4.
} 
person narration functions as a means of creating authorial distance, but his highly selective narrative focus and his general sympathy for Pullman allows Pullman to function as something approaching the first-person narrators of the traditional apocalypse, such as Enoch, Baruch, or John. The signs of God that transform Pullman's semiotic reality-or the intrusion of the ancient conceptions of heaven, purgatory, and hell in an otherwise modernized landscape-suggest not only a transformation of genre but a corresponding transformation of the implied author from detached satirist to religious visionary.

This change in Lewis has not been explored in detail, but a number of Lewis critics, including Kenner, Edwards, and Daniel Schenker, have noted that Pullman's transformation constitutes at least an implied critique or modification of Lewis's earlier political and religious ideas. ${ }^{43}$ Kenner, who befriended the aging Lewis, reveals how closely Lewis, as he was preparing to write The Trial of Man, identified with the struggle of his protagonist:

Lewis's mind in those last days was taken up with Pullman, with whom his imagination had now identified itself. Sammael interested him little, as did satire. ... He was no longer interested in the dozens of earlier books in which he had invested so much that was incompatible with the divinization of Pullman; not

\footnotetext{
${ }^{43}$ Brian James Murray, in a doctoral thesis entitled "Awaiting the Apocalypse: The Later Novels and Short Stories of Percy Wyndham Lewis," examines the currents of apocalypticism in Lewis's later fiction, but he focuses almost entirely on Lewis's vision of an impending social apocalypse-in other words, one without supernatural involvement. Also, his discussion of The Human Age comes to no definite conclusion in regards to Lewis's opinions on God and suggests that Lewis essentially remained a devotee of the politics of the intellect to the end of his life. More recently, Jonathon Penny, in his doctoral thesis "An Experiment in Critical Modernism: Eschatology, Prophecy, and Revelation in Lewis, Huxley, and Golding," incorporates Lewis into a study of apocalypticism in twentieth-century British literature, although he focuses specifically on Blast (1914) and Tarr (1918) and does not address The Human Age in any detail.
} 
only illness and fatigue, it seemed, but a new quality of preoccupation with human destiny had made them dwindle in his mind. ${ }^{44}$

He describes Lewis's willingness to reconsider the idea of the supremacy of the intellect as "the most extraordinary deed in his [Lewis's] long career," $"$ although he suggests that this project would have been confined primarily to The Trial of Man, had Lewis lived to write it. I would suggest that such a transformation is already in progress throughout Monstre Gai and Malign Fiesta-in Pullman's parody of the Politics of the Intellect, the liminality of the afterworld, the conflict of semiotic realities within Pullman's consciousness, and the fluctuation in genre from allegorical satire to religious apocalypse.

By taking the idea of the afterlife seriously, Lewis adds an entirely new dimension to his conceptualization of the kulturkampf. The Old/New division, which is tearing apart the afterworld, is replaced by a division between good and evil, and The Human Age represents the beginnings of a new, partisan religious perspective in which the political is associated with the specifically Satanic. An entirely new strategy is suggested: if the politics of the intellect inevitably lead one into evil, then an intellectual with even a spark of moral conscience has no choice but to side wholeheartedly with the good. The decision can be put off almost indefinitely, as Pullman shows, but it must eventually be made.

If the fundamental friend/enemy division underlying the political itself can never be overcome, there is no choice for the intellectual but to accept the role of the eternal

\footnotetext{
${ }^{44}$ Kenner, "The Trial of Man," 239-240.

${ }^{45}$ Ibid., 234.
} 
outsider. By considering the plight of the eternal outsider-or the Lewisian intellectual in the afterlife-in The Human Age, Lewis realized that his politics of the intellect were ultimately unsupportable. It was only through the failure of the politics of the intellect in The Human Age that Lewis was able finally to triumph over the kulturkampf. This triumph was hard-won; Lewis's lifelong battle with the cultural contradictions of his time and his championing of the politics of the intellect led him through periods of social ostracization, poverty, and exile, and it was only when faced with blindness and the reality of his own mortality that he made the decision to abandon his policy of nonpartisanship. In his apocalyptic mode of thinking, he may have considered Jesus' words to the church in Laodicea in the Book of Revelation: "II know about your activities: how you are neither cold nor hot. I wish you were one or the other, but since you are neither hot nor cold, but only lukewarm, I will spit you out of my mouth." ${ }^{\prime 46}$ The Human Age suggests that even if the intellectual realm transcends the political realm, these are both transcended by the religious realm; if Lewis had lived long enough to revise fully his politics of the intellect, it is likely that they would have been geared towards serving the interests of the divine intelligence rather than the human intelligence Lewis so artfully defended through much of his turbulent career.

\footnotetext{
${ }^{46}$ Revelation 7:15-16. The New Jerusalem Bible, 1419.
} 


\section{Conclusion and Epilogue}

In one particular sense of the term, Lewis may be considered a thorough reactionary. The changes in his political stances, as reflected in the development of his authorial persona, reflect his acute sensitivity to new cultural and political developments-a sensitivity that forced him into a constant state of frenetic reaction as he strove to position himself outside the friend/enemy alignments of the modern kulturkampf. If he could have been content with being a true outsider, completely detached from society, his career would likely have followed a much smoother trajectory. Instead, he refused to relinquish his concern for society at large and sought to bring the kulturkampf into a state of political equilibrium; he also refused, despite his cynicism, to see other individuals as lost causes, and wrote with an evangelical purpose, offering potential freedom from kulturkampf conformity for those with ears to listen.

Since Lewis's death in 1957, kulturkampf rhetoric in Western culture has undergone a number of transformations but maintains its attachment to the fundamental distinction between the Old and the New. The 1960s saw the kulturkampf reach a point of particular intensity in both North America and Europe, ${ }^{1}$ and its friend/enemy divisions continue to bisect the Western cultural landscape. The old political categories of Left and Right, which achieved such intensities of significance in the 1930 s, have not given way to

\footnotetext{
${ }^{1}$ Irving Horowitz, in the 1968 edition of his Radicalism and the Revolt Against Reason: The Social Theories of George Sorel, includes a preface describing the similarities between Sorelian thought and 1960 s American radicalism. The comparison is certainly valid, although I disagree with his remark that "current radicalism resembles the fin de siècle nineties rather than the proletarian thirties." Horowitz, Radicalism and the Revolt Against Reason, v. As Lewis revealed in works ranging from The Art of Being Ruled (1926) to The Doom of Youth (1932), political radicalism of the Sorelian variety flourished with particular intensity in the late 1920s and 1930s.
} 
a plurality of political perspectives in the postmodern era, and have consistently drawn political discourse into familiar binary patterns-even in the intellectual world. As Lewis and Julien Benda both predicted, the status of the unpolitical intellectual in the West has declined, and thinking and research that is not clearly and directly relevant to the social life of both the nation and the international community has become increasingly marginalized. It is surprising that, in such a cultural environment, Lewis's legacy has failed to inspire any significant number of dissident voices.

Mention of Lewis's name in the post-war literature of the kulturkampf is scarce. Lewis, for whatever reason, did not become a post-war cultural touchstone, unlike many other politically controversial writers of his era, such as William Butler Yeats, Ezra Pound, W.H. Auden, and even Louis-Ferdinand Céline. The trail of his legacy is faint, but it can be found tracing a curious path through the literary battlegrounds of the kulturkampf, often being twisted in ways that contradict the essential principles of his politics of the intellect.

Post-war intellectuals have largely been silent regarding the problems identified by Lewis and Benda, although some dubious attempts to rectify the situation have emerged from American conservative critics. Two controversial examples are Allan Bloom's seminal culture-war text, The Closing of the American Mind: How Higher Education Has Failed Democracy and Impoverished the Souls of Today's Students (1987), and Roger Kimball's vitriolic Tenured Radicals: How Politics has Corrupted Our 
Higher Education (1990). ${ }^{2}$ For all their protestation at the intrusion of the political into higher education, however, Bloom, Kimball, and their imitators most often state their case using the one-sided rhetoric demanded by the friend/enemy distinction of the kulturkampf. It is especially interesting, then, that one example of Lewis's lasting cultural resonance is the sympathetic reception of his work among the post-war American conservatives who established the polemical tradition in which Bloom and Kimball are situated. Likely, it is no coincidence that Saul Bellow, in his foreword to Bloom's The Closing of the American Mind, chose to paraphrase Lewis-specifically a passage from Lewis's America and Cosmic Man (1949), in which Lewis describes the plight of the young, North American, potential artist/intellectual. The original passage reads as follows: "The young man or woman of unusual gifts might just as well have been born in Eskimo Land as in such an environment as this; better, in fact, for as Eskimos they would have been spared all these beautiful works of art, these massed books full of disturbing knowledge, produced in more propitious times and places - spared the frustrations such cultural excitements provoke."3 Lewis's description of American culture as a wellmaintained facade jibes well with Bloom's description of a supposedly "cultured" generation that has become alienated from Western cultural traditions.

Lewis's warm reception among American conservatives occurred shortly after his return to England from North America, in the work of two post-war conservative

\footnotetext{
${ }^{2}$ Kimball also wrote the introduction for a recent (2006) edition of Julien Benda's The Treason of the Intellectuals, published by Transaction Publishers.

${ }^{3}$ Bellow, foreword to The Closing of the American Mind, 14. Lewis, America and Cosmic Man, 211.
} 
pioneers: Henry Regnery and Russell Kirk. Regnery and Kirk were the co-founders of the journal Modern Age, in which Regnery's "T.S. Eliot, Ezra Pound, and Wyndham Lewis: A Creative Friendship," was first published in 1972. The journal, according to Kirk, was intended to follow in the tradition of Seward Collins' The American Review and The Bookman (the journal that later became The American Review). Kirk writes, "Certain Modernist excesses incited ... [us] to found a periodical comparable to the vanished Bookman and the American Review that might publish reflections on the permanent things and offer some intellectual resistance to a reckless neoterism. ... Modern Age was intended to become, in considerable part, an American protest against the illusions of Modernity; and so it has remained." In many ways, the integration of Lewis (as well as other modernists) into the post-war conservative American tradition was a continuation of the work carried out by Seward Collins and Geoffrey Stone.

Regnery was a consistent champion of Lewis's work, and wrote about him extensively in his published memoirs. ${ }^{5}$ Regnery Publishing, which was founded in 1947 and still flourishes today, helped to define and popularize post-war conservatism in America; some of the conservative classics published by Regnery Publishing include William F. Buckley Jr.'s God and Man at Yale: The Superstitions of "Academic Freedom" (1951) and Russell Kirk's The Conservative Mind: From Burke to Santayana

\footnotetext{
${ }^{4} \mathrm{Qtd}$. in Panichas, xxiv. The source for the quotation is Kirk's The Sword of Imagination: Memoirs of a Half-Century of Literary Conflict (1995).

${ }^{5}$ Regnery's Perfect Sowing: Reflections of a Bookman (1999) contains "Wyndham Lewis: A Man Against His Time" (as well as an essay on Roy Campbell entitled "Roy Campbell: No Ordinary Man"). A Few Reasonable Words: Selected Writings (1996) contains "T.S. Eliot, Ezra Pound, and Wyndham Lewis: A Creative Friendship," and Memoirs of a Dissident Publisher (1979) contains "Roy Campbell, Wyndham Lewis, T.S. Eliot, Ezra Pound." Unfortunately, there is some overlap between the essays, with certain passages being reproduced almost verbatim.
} 
(1954). Its more recent publications, which are decidedly more popular and polemical in tone, include such controversial titles as David Horowitz's McCarthyesque The Professors: The 101 Most Dangerous Academics in America, and Mark Steyn's attack on multiculturalism, America Alone: The End of the World as We Know It (2006).

It is unsurprising that Regnery admired and published Lewis, given that Regnery's brand of post-war conservatism is directed against the same left-liberal hegemony that Lewis attacked in his work of the 1920s and 30s. It is, perhaps, also unsurprising that Regnery chose to publish The Revenge for Love, which deals extensively with the conspiratorial machinations of communists in England, in 1952, when American anticommunist paranoia was at its peak. That being said, there is no evidence that Regnery perceived his publication of The Revenge for Love as a contribution to Joseph McCarthy's assault on freedom of political association; rather, he saw it as a strike against an ascendant and suffocating liberalism. In one of his memoirs of his publishing career, Regnery writes that The Revenge for Love "was first published in England in 1937; our edition, the first in the United States, appeared in 1952. If one asks why a major novel by one of the greatest writers of this century had to wait fifteen years to find an American publisher, the answer is quite simple: it ran counter to the prevailing orthodoxy of liberalism. ${ }^{.6}$ In a separate memoir, he attributes negative reviews of the novel to liberal intolerance, remarking that "The guardians of the liberal status quo operate with a zeal and single-mindedness which Torquemada would have admired." It would seem that for

\footnotetext{
${ }^{6}$ Regnery, "Roy Campbell, Wyndham Lewis, T.S. Eliot, Ezra Pound," 206.

${ }^{7}$ Regnery, "Wyndham Lewis: A Man Against his Time," 107.
} 
Regnery, the publication of The Revenge for Love was a political act, and its unsympathetic reception a vindication of his own convictions regarding the politics of the American literati.

Although Regnery's accusations regarding "the prevailing orthodoxy of liberalism" would have rung false had they been made in 1952 (rather than in a 1979 memoir), there is some truth to the idea that Lewis, when compared to many lesser but "politically correct" authors, suffered a disproportionate amount of censure and indifference in America. Regnery, in yet another memoir, remarks that "Since his [Lewis's] death, Cornell and the University of Buffalo have spent large sums accumulating Lewis material-manuscripts, letters, first editions, drawings, etc. When they could have done something for Lewis himself, they ignored him." Here, Regnery is accurate: the same schools that now hoard his belongings had no interest in the man himself. One might add that the Canadian intellectual establishment (with the exception of Assumption College in Windsor) expressed a similar indifference towards Lewis when he lived in Canada-but perhaps more out of apathy and incuriosity than for political reasons. For Regnery, it would appear, Lewis was more than an unjustly neglected writer; he was living proof of a liberal conspiracy that sought to quash all non-progressive thought.

Russell Kirk is another prominent American conservative who took an interest in Lewis, and even visited him circa $1955 .{ }^{9}$ Although he did not include Lewis in his list of

\footnotetext{
${ }^{8}$ Regnery, "T.S. Eliot, Ezra Pound, and Wyndham Lewis: A Creative Friendship," 316.

${ }^{9}$ Rose, The Letters of Wyndham Lewis, 563, note 1.
} 
conservative thinkers in The Conservative Mind, he did, as W.K. Rose surmises, send Lewis copies of The Conservative Mind, A Program for Conservatives (1954), and Academic Freedom (1955). ${ }^{10}$ Lewis's enthusiastic response to Kirk is surprising, given that at this point in his career, Lewis publically displayed little fondness for the traditionalism of which Kirk is representative. In an August 1955 letter to Kirk, he writes, "You are the latest, and by no means the least, of that brilliant group of Americans advocating that of all unamerican things, the Traditional Spirit. Your praise of Edmund Burke is very much to my taste." ${ }^{11}$ As with his letter to Geoffrey Stone regarding America and Cosmic Man, Lewis displays a sly private appreciation for an ideology he publicly rejected.

Kirk's interest in Lewis at that time extended beyond friendly communication; Kirk also published a sympathetic article on Lewis entitled "Wyndham Lewis's First Principles" (1955). In the article, Kirk, to his credit, does not insist on painting Lewis as a conservative-or at least not a conservative of the usual variety. He displays an understanding both of Lewis's politics of the intellect and its consequences for the unpolitical writer, writing that "We dwell in an age of ideologies, so that detachment is denounced as treason. For many people, it has become impossible to conceive that anyone should not be an ideologist. Mr. Lewis, not being a Marxist, was attacked as a Fascist; his critics did not admit the possibility of his detesting all forms of collectivism

\footnotetext{
${ }^{10}$ Ibid., note 3.

${ }^{11}$ Lewis to Russell Kirk, London, 29 August 1955, in Rose, ed., The Letters of Wyndham Lewis, 563.
} 
and fanaticism." ${ }^{\prime 2}$ However, the detachment that Kirk identifies as an exceptional trait in Lewis is also one that he seeks to question. As his title suggests, he is eager to determine the "first principles" that motivate Lewis-"first principles" being conservative terminology for what otherwise might be referred to as "ideological foundations."

As a conservative, Kirk is not interested in ideologies, but in absolute values; however, like those who accuse Lewis of ideological "treason," Kirk rebels against Lewis's non-partisan stance. Predictably, in his effort to determine the framework of ideas within which Lewis operates, he misinterprets Lewis's political message. He concludes that Lewis, underneath his veil of contradiction, is acting in defense of nineteenth-century liberalism, ${ }^{13}$ and laments that Lewis's veiled conservatism does not extend further back into the realm of history. ${ }^{14}$

Kirk predicts that Lewis will never emerge from his shell of detachment, and thus ultimately feels obligated to dismiss him as little more than an interesting relic-a man of his time who has little to offer the future. He compares the aging Lewis in Notting Hill to Samuel Taylor Coleridge at Highgate, where Coleridge spent the last years of his life in a state of reactionary withdrawal. In addition, he predicts, with some accuracy, that Lewis's outsider stance will doom him to semi-obscurity, given that Lewis does not offer the kind of clear and two-dimensional worldview craved by the post-war youth: "The rising generation will not look to Wyndham Lewis at Notting Hill as once they looked to Coleridge at Highgate, for Notting Hill is much further down the river, and the dry rot

\footnotetext{
${ }^{12}$ Kirk, "Wyndham Lewis's First Principles," 535

${ }^{13}$ Ibid., 526 .

${ }^{14}$ Ibid., 527.
} 
works there nowadays with a malignant cunning. It would do them no harm to go to Mr. Wyndham Lewis: he would tell them some hard truths, of which we all stand in need. I think that a good many of them are going to read Lewis, these next few years, but that they will have to look elsewhere for some consolation or guidance. Lewis points the way to nothing; yet he stands for something manly and free, and for the cold scorn of the real satirist." ${ }^{15}$ Kirk ultimately offers a mix of praise and damnation, suggesting that Lewis's otherwise admirable "cold scorn" is what removes him both from the kulturkampf and from contemporary relevance.

Although Regnery and Kirk were the two American conservatives most receptive to Lewis, his name continued to appear occasionally in the literature of conservatism; sympathetic reviews of Lewis's work can be found in later issues of Modern Age ${ }^{16}$ Hugh Kenner, the famous Canadian critic who was friends with Lewis and wrote an important early academic monograph on his work, was involved in the American conservative cultural sphere. He was a frequent contributor to National Review in the 1950s, and his attack on John Harrison's portrayal of the great modernists, including Lewis, as simple reactionaries appeared in Buckley's American Conservative Thought in the Twentieth Century. ${ }^{17}$

Outside of the conservative camp, Lewis's name does not appear with any frequency in the literature of the post-war North American kulturkampf. One exception,

\footnotetext{
${ }^{15}$ Ibid., 534.

${ }^{16}$ In Modern Age, see John Russell's 'Proletarian Tragedy: Wyndham Lewis' 'Revenge for Love'," Charles C. Clark's review of Timothy Materer's Vortex: Pound, Eliot, and Lewis, and Anthony Kerrigan's review of Lewis's Mrs. Dukes' Million.

${ }^{17}$ Kenner, "The New Scholarship: The Relevance of 'The Reactionaries'."
} 
however, is C.P. Snow's kulturkampf text, The Two Cultures (1959), in which Snow laments the divide between an aging generation of traditional intellectuals (of which he counts Lewis as one representative) and a new generation of pragmatic intellectuals who see science as the primary guiding force in the development of humanity. Snow recalls a prominent scientist asking him, "“Yeats, Pound, Wyndham Lewis, nine out of ten of those who have dominated literary sensibility in our time-weren't they not only politically silly, but politically wicked? Didn't the influence of all they represent bring Auschwitz that much nearer?""18 Unwilling to "defend the indefensible," Snow acknowledges in response that "there is, in fact, a connection, which literary persons were culpably slow to see, between some kinds of early twentieth-century art and the most imbecile expressions of anti-social feeling." 19 In a manner typical of a kulturkampf partisan, Snow is unwilling to explore or give any credence to the complexities of modernist politics, and naively assumes that they were merely behind the times, as "Literature changes more slowly than science. ${ }^{20}$ If they had only been fully aware of the paths to social progress that science offers, Snow naively suggests, they might have adopted liberal attitudes.

Perhaps the only post-war thinker who has been able to synthesize the different aspects of Lewis's legacy-including, to some extent, his politics of the intellect-is his onetime friend and disciple, Marshall McLuhan. Through the work of McLuhan, Lewis's thought has filtered into the realms of both popular culture and academic cultural studies, leaving an ignored but nevertheless indelible mark on the twentieth-century kulturkampf.

\footnotetext{
${ }^{18}$ Snow, The Two Cultures, 7.

${ }^{19}$ Ibid., 7-8.

${ }^{20}$ Ibid., 8.
} 
McLuhan is, of course, best known as the new-media maverick of 1960s culture, and the purveyor of buzz-phrases like "the medium is the message" and "the global village." The myriad of connections between the work of Lewis and McLuhan are too intricate to delve into here; it will suffice to examine briefly the extent to which Lewis's politics, and his politics of the intellect, entered into McLuhan's strategies for engaging with a politicized public.

Like Lewis, McLuhan strove to project a public persona that was detached, elusive, and politically ambiguous. Although he was known to be a devout Roman Catholic, he was embraced by the counterculture that developed in 1960s North America. It is only recently that some academic critics have argued that McLuhan's Catholicism must be seen as a constant covert presence in his writings, and that he belonged to the political Right as much as to the Left. Like Lewis, McLuhan attempted to engage with both sides of the political spectrum, creating an ambiguity that situated him as a political outsider.

The range of reactions that McLuhan's work provoked in the 1960s can be surveyed in McLuhan: Pro and Con (1968), a collection of essays on McLuhan from a variety of his fans and detractors, including Hugh Kenner and Geoffrey Wagner. Neil Compton, in an essay in the book entitled "The Paradox of Marshall McLuhan," provides an early study of the implications of McLuhan's Catholicism, particularly in relation to McLuhan's early essays and The Mechanical Bride (1951). Compton describes what he sees as the paradox of McLuhan: "The paradox is that this darling of marketing associations and the switched-on set idealizes the twelfth century, dislikes almost 
everything about the twentieth century to date (except its art), and has never really wavered in his loyalty to one of the most orthodox and conservative (not to say reactionary) of intellectual traditions." ${ }^{21}$ Although Compton sees an explicit Catholic influence primarily in McLuhan's early work, he also acknowledges that "In his later work he [McLuhan] drew heavily upon the Tory triumvirate of Eliot, Pound, and Wyndham Lewis."22

Two more recent critics have explored the issue of McLuhan's Catholicism, once again challenging the view that McLuhan was writing primarily for the 1960s counterculture. In a long review essay on W. Terrence Gordon's Marshall McLuhan, Escape into Understanding in Modernism/modernity, Mark Krupnick situates McLuhan as a "catholic modernist," arguing that "implicit always in his account of the electronic world aborning is a desire to serve as midwife for an order that will restore the Catholic Middle Ages as he imagined them to have been."23 Grant Havers offers a similar thesis, arguing that McLuhan's ideas represent a form of "Right-Wing Postmodernism." He argues that "a close hermeneutical reading of McLuhan's major writings reveals a type of conservatism that anticipates the emergence of a more tribalistic, stringently moralistic and technologically sophisticated age, succeeding the liberal, modernist, individualist age of modernity. ${ }^{.24}$ Havers brings Lewis into his discussion, describing Lewis as one of the "sources of right-wing anti-liberalism and anti-capitalism ... in McLuhan's work,"25

\footnotetext{
${ }^{21}$ Compton, 107.

${ }^{22}$ Ibid., 107-108.

${ }^{23}$ Krupnick, "Marshall McLuhan Revisited: Media Guru as Catholic Modernist," 108.

${ }^{24}$ Havers, "Right-Wing Postmodernism," 512.

${ }^{25}$ Ibid., 516.
} 
adding that "In his essay, 'Wyndham Lewis: Lemuel in Lilliput,' McLuhan echoed conservative sentiments shared with Lewis over the loss of the traditional ties that bind community, ties which were steadily eroded by liberal individualism." ${ }^{26}$ Whether McLuhan held these sentiments is debatable, but it should be clear from any careful reading of Lewis's work that as an intellectual outsider he did not cling to "the traditional ties that bind community." Havers adds, however, that "Ironically, Lewis's role as a rightist critic of social change and liberalism has become transformed, like McLuhan's, into the image of a leftist critic of capitalism.."27 What Havers does not consider is that this transformation is the result of a fundamental ambiguity in the work of Lewis and McLuhan that allows, and even invites, such varieties of interpretation to take place.

Despite Havers' miscasting of Lewis as a traditionalist, there is some truth in his argument regarding Lewis's influence on McLuhan. McLuhan's strategies, as Havers suggests, ${ }^{28}$ have their roots in the period during which McLuhan maintained close contact with Lewis. In the aforementioned 1944 essay, "Wyndham Lewis: Lemuel in Lilliput," McLuhan attempts to integrate Lewis's work with Catholic thought, using Lewis as a model of how to engage intellectually with both the Old and the New. His description of the lack of modernist influence in the development of Catholic thought is worth quoting at length:

the time-lag in the Catholic reading public is such that although Catholics necessarily live in the world of Eliot, Stein, and Einstein, their emotional

\footnotetext{
${ }^{26}$ Ibid.

${ }^{27}$ Ibid.

${ }^{28}$ Ibid.
} 
organization is done for them by Kipling, Galsworthy, Shaw, and Chesterton. For let us not suppose for one instant that Catholicity of mind is conferred by grace or that we are freed from "the world's slow stain" by immersing ourselves in the best sellers of yesteryear.

All question of the artistic value of Joyce and Picasso apart, the man whose sensibility and judgement cannot cope with them easily and naturally has not the equipment to consider the world he lives in. Certainly there can be no Catholic action at the educated level until this equipment is acquired and mastered-a fact which explains why the Catholic mind never has to be seriously considered by the non-Catholic mind in England and America today. ${ }^{29}$

He considers Jacques Maritain to be an example of a Catholic who demands such serious consideration, remarking that "He can mesh with the modern mind, such as it is. He can impinge. ${ }^{\jmath 30}$ Realizing, perhaps, that Maritain's academicism might repel the average Catholic, he offers the following remarkable prescription: "For the English-speaking Catholic who would do likewise but who knows not how to begin (and his formal education will not be of any assistance in this matter), let him pore upon the works of Wyndham Lewis, let him read by day and meditate by night." ${ }^{31}$ McLuhan presents Lewis's works here as a type of holy writ-capable of exerting a transforming influence on those who are trapped in the conventional stances adopted by Catholic participants in the kulturkampf. McLuhan's linking of Lewis and Maritain (who met each other in 1942)

\footnotetext{
${ }^{29}$ McLuhan, "Wyndham Lewis: Lemuel in Lilliput," 180.

${ }^{30}$ Ibid.

${ }^{31}$ Ibid.
} 
suggests that Lewis's thought, like Maritain's, represents a path through which faithful Catholics might improve their understanding of the modern world without sacrificing their religious values. ${ }^{32}$ McLuhan's recommendation must surely have been flattering to Lewis, who hoped that through his unique brand of evangelism, he could transform his politically partisan readers into something far more complex.

McLuhan's development of the idea of incorporating Lewis into a less twodimensional engagement with the kulturkampf is apparent in a letter to professor Clement McNaspy, written in 1945 from Assumption College. In this letter, McLuhan again attempts to formulate a method by which the Catholic thinker might engage with the secular world:

It seems obvious that we must confront the secular in its most confident manifestations, and, with its own terms and postulates, to shock it into awareness of its confusion, its illiteracy, and the terrifying drift of its logic. There is no need to mention Christianity. It is enough that it be known that the operator is a Christian. This job must be conducted on every front-every phase of the press, book-rackets, music, cinema, education, economics. Of course, points of reference must always be made. That is, the examples of real art and prudence must be seized, when available, as paradigms of future effort. In short, the methods of F.R. Leavis and Wyndham Lewis applied with all the energy and order denied them from faith and philosophy - these can serve to educate a huge public, both Catholic and non-Catholic, to resist that swift obliteration of the person which is

\footnotetext{
${ }^{32}$ Lewis's Rude Assignment contains a photograph of Lewis and Maritain, dated 1942.
} 
going on. ${ }^{33}$

McLuhan is offering directives for the conducting of a culture war, one "conducted on every [cultural] front." McLuhan adds, in a somewhat Machiavellian manner, that "There is no need to mention Christianity. It is enough that it be known that the operator is a Christian." What this statement implies is that McLuhan, like Lewis, began to realize the need for concealing his own prejudices-although it also suggests that McLuhan's works can be read "esoterically," as coded contributions to a particular kulturkampf faction. ${ }^{34}$ McLuhan's later works, although they are usually read as a celebration of the new, can also be read as a conservative attempt to redirect the path of the 1960s "transition" period towards a new "political equilibrium" (to borrow Lewis's 1920s terminology).

McLuhan's appropriation of Lewis may have injected Lewis's ideas regarding the relationship between the intellectual and society into popular culture, but there is little evidence that McLuhan's efforts have raised Lewis's cultural profile. Lewis remains nobody's hero, and as Kirk predicted, new generations of culture-warriors have consistently ignored Lewis's works. A notable exception is the Canadian culture-critic B.W. Powe, whose 1987 book The Solitary Outlaw derives much of its critical orientation (and its title) from Lewis's works. Lewis, along with Elias Canetti, Glenn Gould, Marshall McLuhan, and Pierre Elliot Trudeau, is held up as an example of a defender of literacy and the intellect in an increasingly anti-intellectual Western world. His reading of Lewis is one that correctly stresses the ideological fluctuations that form the basis of the

\footnotetext{
${ }^{33}$ McLuhan, "Confronting the Secular," 201-202.

${ }^{34}$ The esoteric/exoteric distinction, as it applies to philosophical discourse, is analyzed in Leo Strauss's Persecution and the Art of Writing (1952).
} 
politics of the intellect: "Lewis's philosophy of the outside is a manifesto of mind restoration and preparation, of laughter and remembering. Which is why he has been mislabelled a conservative. Labelling is a way of killing a live thing. And the Lewisite method is meant to outwit the specialist. ... His thinking tried to balance opposites in a rational equilibrium without resorting to an ideological hard line." 35 This statement, although presented in a polemical, non-academic context, offers an interpretation of Lewis's methods that has often become submerged in Lewis criticism, and which is in strong accordance with my interpretation of Lewis.

It would seem that Powe is the last remaining writer in the popular realm to present Lewis's work as a potential model for cultural criticism. The academic study of Lewis will continue, of course. Indeed, it seems that Lewis's status in the humanities is on the rise; Alan Munton has even recently proposed that Lewis should be seen as one of the founders of cultural studies, along with George Orwell. ${ }^{36}$ The irony, however, is that Lewis, despite all of his protestations regarding the debasement of the intellect in the twentieth century, wanted his books to be read by ordinary people. Like Benda, he may have lamented over the "treason of the intellectuals," but he also hoped his books would have a social impact-not on ideologically-driven groups, but on ordinary members of society who might, through the reading of his work, become extraordinary outsiders like himself.

\footnotetext{
${ }^{35}$ Powe, The Solitary Outlaw, 62.

${ }^{36}$ This is the central argument of Munton's Internet-published "George Orwell, Wyndham Lewis and the Origins of Cultural Studies."
} 
Bibliography of Works Cited and Consulted

2 Enoch. Translated by F.I. Andersen. In Charlesworth, The Old Testament Pseudepigrapha, 91-221.

3 Baruch. Translated by H.E. Gaylord, Jr. In Charlesworth, The Old Testament Pseudepigrapha, 653-679.

Allen, James Dresser. "The Apollonian-Dionysian Conflict in the Works of Wyndham Lewis." $\mathrm{PhD}$ diss., University of Washington, 1961.

Allen, Walter. "Lonely Old Volcano: The Achievement of Wyndham Lewis." Encounter 21, no.3 (1963): 63-70.

“An Enemy Worth Having.” Nation 125, no.3254, November 16, 1927, 535.

Ayers, David. Wyndham Lewis and Western Man. New York: St. Martin's Press, 1992.

Babbitt, Irving. Rousseau and Romanticism. Cleveland: Meridian Books, 1964. Reprint of 1955 edition. First published 1919.

Belloc, Hilaire. The Servile State. 3rd ed. London: Constable, 1948. Third edition originally published 1927.

Bellow, Saul. Forward to The Closing of the American Mind, by Allan Bloom, 11-18.

Benda, Julien. The Treason of the Intellectuals. Translated by Richard Aldington. New York: W.W. Norton and Company, 1969. First published in 1927 as La Trahison des Clercs.

Bergonzi, Bernard. "Roy Campbell: Outsider on the Right." Journal of Contemporary History 2, no.2 (April 1967): 133-147.

Blackmur, R.P. Review of The Lion and the Fox, by Wyndham Lewis. Hound \& Horn 1, 
no.1 (September 1927): 42-47.

Blanton, C.D. "The Politics of Epochality: Antinomies of Original Sin." In T.E. Hulme and the Question of Modernism, edited by Edward P. Comentale and Andrzej Gąsiorek, 187-208. Aldershot: Ashgate, 2006.

Bloom, Allan. The Closing of the American Mind. Foreword by Saul Bellow. New York: Touchstone, 1988. First published 1987.

Booth, Wayne C. The Rhetoric of Fiction. $2^{\text {nd }}$ edition. Chicago: The University of Chicago Press, 1983. First published 1961.

Bradley, F.H. Appearance and Reality: A Metaphysical Essay. $2^{\text {nd }}$ ed. London: Oxford University Press, 1897. First published 1893.

Bridson, D.G. The Filibuster: A Study of the Political Ideas of Wyndham Lewis. London: Cassell, 1972.

Brown, Dennis. "Prophesying the Postmodern: Wyndham Lewis's America and Cosmic Man." Wyndham Lewis Annual 5 (1998): 9-22.

Buckley, William F., Jr., ed. American Conservative Thought in the Twentieth Century. The American Heritage Series. Indianapolis: The Bobbs-Merrill Company, Inc., 1970.

Burstein, Jessica. "Prosthetic Fictions: Cold Modernism in Wyndham Lewis, Mina Loy, and Evelyn Waugh." PhD diss., University of Chicago, 1998.

Campbell, Roy. Broken Record. London: Boriswood, 1934.

-----. "Talking Bronco." In Collected Works, volume 1, edited by Peter Alexander, Michael Chapman, and Marcia Levenson, 407-416. Craighall: AD. Donker, 1985. 
-----.. Wyndham Lewis. Ed. Jeffrey Meyers. Pietermaritzburg: University of Natal Press, 1985

Campbell, SueEllen. The Enemy Opposite: The Outlaw Criticism of Wyndham Lewis. Athens: Ohio University Press, 1988.

Canti, Giovanni, ed. Wyndham Lewis: Letteratura/Pittura. Palermo: Sellerio editore, 1982.

Caracciolo, Peter L. "From Signorelli to Caligari: Allusions to Painting and Film in The Human Age and its Visual Precursors." In Cunchillos Jaime, Wyndham Lewis the Radical, 137-157.

-.----, and Paul Edwards. "In Fundamental Agreement: Yeats and Wyndham Lewis." Yeats Annual, no.13 (1998): 110-157. Ed. Warwick Gould. Basingstoke: Macmillan, 1998.

-----. “The Metamorphoses of Wyndham Lewis's The Human Age: Medium, Intertextuality, Genre." In Modernist Writers and the Marketplace, edited by Ian Willison, Warwick Gould, and Warren Chernaik, 258-286. New York: St. Martin's Press, 1996.

Carlyle, Thomas. Past and Present. Edited by Richard D. Altick. New York: New York University Press, 1965. First published 1843.

Carroll, David. French Literary Fascism: Nationalism, Anti-Semitism, and the Ideology of Culture. Princeton: Princeton University Press, 1995.

Cassidy, Victor M. “Who was Wyndham Lewis?” New Criterion, June 1993, 26-38.

Chapman, Robert T. Wyndham Lewis: Fictions and Satires. Vision Critical Studies. 
General editor Michael Egan. London: Vision Press, 1973.

Charlesworth, James H. The Old Testament Pseudepigrapha. Volume 1. Edited by James H. Charlesworth. Garden City, New York: Doubleday and Company, 1983.

Chesterton, G.K. "The Doom of Doom: A Reply to Mr. Wyndham Lewis's Articles on Youth-Politics [part 1]." Time and Tide 12, no.31 (1 August 1931): 910-913.

----.. “The Doom of Doom [part 2]." Time and Tide 12, no.32 (8 August 1931): 935-936.

-----. Orthodoxy. N.c.: Fontana, 1963. Reprint of 1961 edition. First published 1908.

-----.. What's Wrong with the World. San Francisco: Ignatius Press, 1994. First published 1910 by Dodd, Mead and Company.

Chuang-Tzŭ. "Khî Wû Lun, or 'The Adjustment of Controversies."” In The Texts of Taoism, translated by James Legge, 224-245. New York: The Julian Press, Inc., 1959. Legge translation first published 1891.

Clark, Charles C. "The Vorticist Experience." Review of Vortex: Pound, Eliot, and Lewis, by Timothy Materer. Modern Age 25, no. 4 (Fall 1981): 428-430.

"Classic Inhumanism." Unsigned review of Wyndham Lewis: A Portrait of the Artist as the Enemy, by Geoffrey Wagner. Times Literary Supplement, August 2, 1957, $465-467$.

Collins, John J. The Apocalyptic Imagination. New York: Crossroad, 1984.

Collins, Seward. "Editorial Notes: The American Review's First Year." The American Review 3, no.1 (April 1934): 118-28.

-----. "Wyndham Lewis's New Tract for the Times." Introduction to Count Your Dead: They are Alive! [excerpt] by Wyndham Lewis, 268-95. American Review 9, no.2 
(Summer 1937): 266-68.

Compton, Neil. "The Paradox of Marshall McLuhan." In Rosenthal, McLuhan: Pro and Con, 106-124.

Conroy, Mark. "Wyndham Lewis's Authoritarian Temptation." SHR 30, no.1 (Winter 1996): 21-33.

Cooney, Seamus, ed. Blast 3. Co-edited by Bradford Morrow, Bernard Lafourcade, and Hugh Kenner. N.c.: Black Sparrow Press, 1984.

Corbett, David Peters, ed. Wyndham Lewis and the Art of Modern War. Cambridge: Cambridge University Press, 1998.

Corrin, Jay P. Catholic Intellectuals and the Challenge of Democracy. Notre Dame, Indiana: University of Notre Dame Press, 2002.

-----. G.K. Chesterton \& Hilaire Belloc: The Battle Against Modernity. Athens, $\mathrm{OH}$ : Ohio University Press, 1981.

Cullis, Michael F. "Lewis at the Time of Munich." Enemy News, no.10 (May 1979): 6-8. Cunchillos Jaime, Carmelo, ed. Wyndham Lewis the Radical: Essays on Literature and Modernity. Bern: Peter Lang, 2007.

Cunningham, Valentine. British Writers of the Thirties. Oxford: Oxford University Press, 1988.

D'Arcy, M.C. The Nature of Belief. Westport, Connecticut: Greenwood Press, 1976. Reprint of 1958 edition. First published 1931.

Dasenbrock, Reed Way. Afterword to The Art of Being Ruled by Wyndham Lewis, $432-447$. 
------. Afterword to The Revenge for Love, by Wyndham Lewis, 387-394.

-----. The Literary Vorticism of Ezra Pound and Wyndham Lewis: Towards the Condition of Painting. Baltimore: John Hopkins University Press, 1985.

-----. "The Metaphysics of the Not-Self: Lewis’s Explorations in Buddhism." Enemy News, no.29 (Winter 1989): 11-14.

-----. Truth and Consequences: Intentions, Conventions, and the New Thematics. Pennsylvania: Pennsylvania State University Press, 2001.

-----. "Wyndham Lewis's Fascist Imagination and the Fiction of Paranoia." In Golsan, ed., Fascism, Aesthetics, and Culture, 81-97.

Douglas, C.H. Credit Power and Democracy. 2nd ed. London: Cecil Palmer, 1921. First published 1920.

Edwards, Paul. "The Critical Reception of Time and Western Man." In Lewis, Time and Western Man, 509-513.

-----. "Explanatory Notes." In Lewis, Rotting Hill, 303-341.

-.---. "Self and Not-Self." Review of Wyndham Lewis: Religion and Modernism, by Daniel Schenker, and Wyndham Lewis and Western Man, by David Ayers. Times Literary Supplement, 1 January 1993, 22.

------, ed. Volcanic Heaven: Essays on Wyndham Lewis's Painting and Writing. Santa Rosa: Black Sparrow Press, 1996.

-----. Wyndham Lewis: Painter and Writer. New Haven, CT: Yale University Press, 2000.

Eliot, T.S. After Strange Gods: A Primer of Modern Heresy. New York: Harcourt, Brace 
and Co., 1934.

----.-. "The Lion and the Fox." Twentieth Century Verse, no.6-7 (November/December 1937): 109-112.

Essays on Wyndham Lewis. N.c.: Folcroft Library Editions, 1971.

Feijó, António M. Near Miss: A Study of Wyndham Lewis (1909-1930). Literature and the Visual Arts: New Foundations. Volume 11. General editor Ernest B. Gilman. New York: Peter Lang, 1998.

Ferrall, Charles. Modernist Writing and Reactionary Politics. Cambridge: Cambridge University Press, 2001.

Foshay, Toby Avard. Wyndham Lewis and the Avant-Garde: The Politics of the Intellect. Montreal: McGill-Queen's University Press, 1992.

Frye, Northrop. “The Diatribes of Wyndham Lewis: A Study in Prose Satire.” In Northrop Frye 's Student Essays, edited by Robert D. Denham, 345-380. Toronto: University of Toronto Press, 1997.

Gąsiorek, Andrzej. Wyndham Lewis and Modernism. Horndon, Tavistock, Devon: Northcote House, 2004.

Gasset, José Ortega y. The Revolt of the Masses. Anonymous authorized translation. New York: W.W. Norton, 1957. First published 1930.

Gawsworth, John. Apes, Japes and Hitlerism. London: Unicorn Press, 1932.

Gellis, Willard Leon. "The Poetics of Reaction: A Study of Wyndham Lewis." PhD diss., New York University, 1970.

George, Margaret. The Warped Vision: British Foreign Policy 1933-1939. University of 
Pittsburgh Press, 1965.

Golsan, Richard J., ed. Fascism, Aesthetics, and Culture. Hanover, NH: University Press of New England, 1992.

Gordon, Nicholl. "Wyndham Lewis: Critical Intelligence." Master's thesis, McGill University, 1995.

Green, E.H.H. Ideologies of Conservatism: Conservative Political Ideas in the Twentieth Century. Oxford: Oxford University Press, 2002.

Grey, Richard. "The Outsider in Twentieth Century English Poetry (some preliminary remarks)." In Outsiders: Roy Campbell, Peter Russell, William Oxley, Anthony L. Johnson, Volume 1, 5-14. Salzburg: Institut Für Anglistik Und Amerikanistik Universität Salzburg, 1989.

Griffiths, Richard. The Reactionary Revolution: The Catholic Revival in French Literature 1870-1914. London: Constable, 1966.

Grigson, Geoffrey. A Master of Our Time: A Study of Wyndham Lewis. London: Methuen, 1951.

H., E.D. Review of Count Your Dead: They are Alive!, by Wyndham Lewis. British Union Quarterly 1, no.3 (July-September 1937): 99-100.

Hanna, Julian. "Blasting After Blast: Wyndham Lewis's Late Manifestos." Journal of Modern Literature 31, no.1 (Fall 2007): 124-135.

Harrison, John R.. The Reactionaries. London: Victor Gollancz, 1966.

Havers, Grant. "The Right-Wing Postmodernism of Marshall McLuhan." Media, Culture \& Society 25, no.4 (2003): 511-525. 
Head, Philip. "An Anarchist with a Healthy Passion for Order: Wyndham Lewis as British Machiavellian." Enemy News, no.14 (Summer 1981): 18-20.

-----. "Counting Your Dead: Lewis and the Anti-War Movements of the Thirties." Enemy News, no.34 (Summer 1992): 14-19.

----. "Ego and Object." In Head, Some Enemy Fight-Talk, 133-142.

-----. "From Diremption to Deconstruction." In Head, Some Enemy Fight-Talk, 153-158.

-----. Engaging the Enemy: The Gentle Art of Contradiction in the Work of Wyndham Lewis. Kent, UK: Green Knight Editions, 2001.

-----. "Ideology, Utopia, Myth." In Some Enemy Fight-Talk, 32-49.

----.. "Lewis and 'the Political'." Wyndham Lewis Annual 12 (2005): $29-41$.

-----. “"Lewis at his Worst'”" Enemy News, no.18 (Autumn 1983): 14-23.

-----.. "Lewis in Pythagorean Mode." In Some Enemy Fight-Talk, 107-120.

-----. Some Enemy Fight-Talk: Aspects of Wyndham Lewis on Art and Society. Kent, UK: Green Knight Editions, 1999.

-----. "The Tyro and the Commissar." In Some Enemy Fight-Talk, 5-23.

The Holy Bible: The New Jerusalem Bible. New York: American Bible Society, n.d. Horowitz, Irving Louis. Radicalism and the Revolt Against Reason: The Social Theories of Georges Sorel. Carbondale: Southern Illinois University Press, 1968. First published 1961.

Hulme, T.E. "Humanism and the Religious Attitude." In Speculations: Essays on Humanism and the Philosophy of Art, edited by Herbert Read, 1-71. London: Routledge and Kegan Paul Ltd., 1960. First published 1924. 
-a--. "A Tory Philosophy." In Jones, The Life and Opinions of T.E. Hulme, 185-201. First published 1912 in The Commentator 4, no.97-98, 101-103.

Hunter, James Davison. Culture Wars: The Struggle to Define America. New York: BasicBooks, 1991.

Jameson, Fredric. Fables of Aggression: Wyndham Lewis, the Modernist as Fascist. Berkeley: University of California Press, 1979.

Jerrold, Douglas. "The Future of the English Political Parties." The English Review 57 (October 1933): 337-358.

-----. Georgian Adventure. William Collins Sons and Company, 1938. Reprinted for The "Right" Book Club. First published 1937.

-----. The Lie About the War: A Note on Some Contemporary War Books. Criterion Miscellany. Number 9. London: Faber and Faber Limited, 1930.

---.-. "What is Conservatism?" English Review 53 (June 1931): 51-62.

John, Henry. "Towards Reintegration [Section III. The Reintegration of Experience]." The Enemy, no.2, edited by Wyndham Lewis (September 1927): 115-137. Reprinted in The Enemy: A Review of Art and Literature 2. London: Frank Cass, 1968.

Jolas, Eugene, Elliot Paul, and Robert Sage. "First Aid to the Enemy." transition, no.9 (December 1927): 161-176. New York: Kraus Reprint Corporation, 1967. Jones, Alun R. The Life and Opinions of T.E. Hulme. London: Victor Gollancz, 1960. Kenner, Hugh. "The Devil and Mr. Lewis." Shenandoah 7, no.1 (1955): 15-30.

-----. "The New Scholarship: The Relevance of 'The Reactionaries." In American 
Conservative Thought in the Twentieth Century, 381-395.

-----. "Stele for Hephaestus." Poetry 9, no.5 (August 1957): 306-310.

-----. “The Trial of Man.” In Lewis, Malign Fiesta, 231-240.

-----. Wyndham Lewis. The Makers of Modern Literature. Norfolk, CT: New Directions Books, 1954.

-----. "Wyndham Lewis: Satirist as Barbarian." In Historical Fictions, 266-281. Athens, GA: University of Georgia Press, 1995.

Kerrigan, Anthony. Review of Mrs. Dukes' Million, by Wyndham Lewis. Modern Age 25, no. 2 (Spring 1981): 220-223.

Kirk, Russell. The Conservative Mind: from Burke to Santayana. Revised edition. Chicago: Henry Regnery, 1954. First published 1953.

-----.. “Wyndham Lewis's First Principles.” Yale Review 44, no. 4 (June 1955): 520-534.

Klein, Scott W. The Fictions of James Joyce and Wyndham Lewis: Monsters of Nature and Design. Cambridge: Cambridge University Press, 1994.

Kojève, Alexandre. Introduction to the Reading of Hegel: Lectures on the Phenomenology of Spirit. Edited by Allan Bloom. Translated by James H. Nichols, Jr. Assembled by Raymond Queneau. Ithaca: Cornell University Press, 1980. First published 1947.

Kolakowski, Leszek. Main Currents of Marxism: Its Origins, Growth and Dissolution. Volume 2: The Golden Age. Translated by P.S. Falla. Oxford: Oxford University Press, 1981.

Krupnick, Mark. "Marshall McLuhan Revisited: Media Guru as Catholic Modernist." 
Review of Marshall McLuhan, Escape into Understanding: A Biography, by W.

Terrence Gordon. Modernism/modernity 5, no.3 (September 1998): 107-122.

Kush, Thomas. Wyndham Lewis's Pictorial Integer. Studies in the Fine Arts: The Avant-Garde. Number 19. Series editor Stephen C. Foster. Ann Arbor, MI: UMI Research Press, 1981.

Landow, George P. Elegant Jeremiahs: The Sage from Carlyle to Mailer. Ithaca: Cornell University Press, 1986.

Lewis, Stephen E. "Love and Politics in Wyndham Lewis's Snooty Baronet." Modern Language Quarterly 61, no.4 (December 2000): 617-649.

Lewis, Wyndham. America and Cosmic Man. Port Washington, N.Y.: Kennikat Press, 1969. First published 1949.

----. Anglosaxony: A League that Works. Toronto: Ryerson Press, 1941.

-----. The Art of Being Ruled. Edited by Reed Way Dasenbrock. Santa Rosa: Black Sparrow Press, 1989. First published 1926.

-----. "The Big Soft 'Centre'." English Review 63, no.1 (July 1936): 27-34.

-----. Blasting and Bombardiering. Berkeley: University of California Press, 1967. First published 1937.

-----. The Childermass. London: Calder, 2000. Reprint of Jupiter edition published 1962 by Calder and Boyars. First published 1928 by Methuen.

-----. Collected Poems and Plays. Edited by Alan Munton. New York: Routledge, 2003. First published in 1979.

----. Count Your Dead: They are Alive! or A New War in the Making. London: Lovat 
Dickson, 1937.

----.. Creatures of Habit and Creatures of Change: Essays on Art, Literature, and Society 1914-1956. Edited by Paul Edwards. Santa Rosa: Black Sparrow Press, 1989.

-----. "The Diabolical Principle." In The Diabolical Principle and The Dithyrambic Spectator, 1-156. London: Chatto and Windus, 1931. First published 1929.

-----. "Detachment and the Fictionist [part 1]." English Review 59 (October 1934): $441-452$.

----.. "Detachment and the Fictionist [part 2]." English Review 59 (November 1934): 564-573.

-----. Doom of Youth. London: Chatto and Windus, 1932.

-----. "The Dumb Ox: A Study of Ernest Hemingway." The American Review 3, no.3 (June 1934): 189-212.

-----. "Editorial notes." Enemy no.2 (September 1927): xi-xxxi. Reprinted in The Enemy: A Review of Art and Literature 2. London: Frank Cass, 1968.

------. Editor's note for Henry John's "Towards Reintegration." Enemy no.2, edited by Wyndham Lewis (September 1927): 115. Reprinted in The Enemy: A Review of Art and Literature 2. London: Frank Cass, 1968.

-----. Enemy of the Stars. In Lewis, Collected Poems and Plays, 93-119. First published in 1914.

-----. "Freedom that Destroys Itself." Listener 13, no.330 (May 1935): 793-794.

----.. "From 'The Infernal Fair"" [selection from the unpublished Joint]. Edited by Hugh 
Kenner. In Essays on Wyndham Lewis, 209-15.

-----. “Great Preliminary Vortex-Manifesto-I.” In BLAST 1 (1914), edited by Wyndham Lewis, 9-28. Santa Barbara: Black Sparrow Press, 1981.

-----. Hitler. London: Chatto and Windus, 1931.

-----. The Human Age. London: Methuen, 1955.

-----. "In Praise of Outsiders." New Statesman and Nation 7, no.168 (12 May 1934): $709-710$.

----.. The Jews-Are They Human? New York: Gordon Press, 1972. First published 1939.

-----.. “'Left Wings' and the C3 Mind.” British Union Quarterly 1, no.1 (January/April 1937): $22-34$.

-----. Left Wings Over Europe: or, How to Make a War About Nothing. London: Jonathan Cape, 1936.

-----. The Lion and the Fox: The Rôle of the Hero in the Plays of Shakespeare.

University Paperbacks. London: Methuen, 1966. First published 1927 by Grant Richards.

-----. Malign Fiesta. In Lewis, The Human Age, 305-566.

-----. Men Without Art. Edited by Seamus Cooney. Santa Rosa: Black Sparrow Press, 1987. First published 1934.

----.. Monstre Gai. In Lewis, The Human Age, 1-304.

-.---. The Mysterious Mr. Bull. London: Robert Hale, 1938.

------. The Old Gang and the New Gang. New York: Haskell House Publishers, 1972. First published 1933. 
-----. Paleface: The Philosophy of the 'Melting Pot.' London: Chatto and Windus, 1929.

-----. "Physics of the Not-Self." In Lewis, Collected Poems and Plays, 193-204.

-----. "Rebel and Royalist." Review of Georgian Adventure by Douglas Jerrold. Spectator no.5701 (October 1 1937): 553.

-----. The Revenge for Love. Edited by Reed Way Dasenbrock. Santa Rosa: Black Sparrow Press, 1991. First published 1937.

------. Rotting Hill. Edited by Paul Edwards. Santa Barbara: Black Sparrow Press, 1986. First published 1951.

-----. Rude Assignment: A Narrative of my Career Up-to-Date. London: Hutchinson, 1951. First published 1950.

------. Time and Western Man. Edited by Paul Edwards. Santa Rosa: Black Sparrow Press, 1993. First published 1927.

-----. The Writer and the Absolute. London: Methuen, 1952.

Light, Alison. Forever England: Femininity, Literature, and Conservatism Between the Wars. London: Routledge, 1991.

Lubac, Henri D. (S.J.). The Un-Marxian Socialist: A Study of Proudhon. Translated by Canon R. E. Scantlebury. London: Sheed and Ward, 1948.

Loewenstein, Andrea Freud. Loathesome Jews and Engulfing Women: Metaphors of Projection in the Works of Wyndham Lewis, Charles Williams, and Graham Greene. New York: New York University Press, 1993.

Low, David. Years of Wrath: A Cartoon History: 1931-1945. With a chronology and text by Quincy Howe. New York: Simon and Schuster, 1946. 
Machiavelli, Niccolò. The Prince. Edited by Peter Bondanella. Translated by Peter Bondanella and Mark Musa. Oxford: Oxford University Press, 1984.

Materer, Timothy, ed. Pound/Lewis: The Letters of Ezra Pound and Wyndham Lewis. New York: New Directions, 1985.

-----. Vortex: Pound, Eliot, and Lewis. Ithaca: Cornell University Press, 1979.

-----.. Wyndham Lewis the Novelist. Detroit: Wayne State University Press, 1976.

McLuhan, Marshall. "Confronting the Secular: Letter to Clement McNaspy, S.J." In The Medium and the Light, 201-202. From letter to Clement McNaspy, S.J., Assumption College, Windsor, Ontario, 15 December 1945 or 15 January 1946.

-----. The Medium and the Light: Reflections on Religion. Edited by Eric McLuhan and Jacek Szklarek. Toronto: Stoddart, 1999.

-----. "Wyndham Lewis: His Theory of Art and Communication." In The Interior Landscape: The Literary Criticism of Marshall McLuhan 1943-1962, edited by Eugene McNamara, 83-94. New York: McGraw-Hill, 1969.

---.-.. "Wyndham Lewis: Lemuel in Lilliput." In The Medium and the Light, 178-197. First published in St. Louis University Studies in Honor of St. Thomas Aquinas 2 (1944): 58-72.

Meyers, Jeffrey. The Enemy: A Biography of Wyndham Lewis. London: Routledge and Kegan Paul, 1980.

------, ed. Wyndham Lewis: A Revaluation. London: Athlone Press, 1980.

Michel, Walter. "Books 'From One of Lewis's Libraries'." Enemy News, no.19 (Summer 1984): 26-37. 
Miller, Tyrus. Late Modernism: Politics, Fiction, and the Arts Between the World Wars. Berkeley: University of California Press, 1999.

-----. "No Man's Land: Wyndham Lewis and Cultural Revolution." Wyndham Lewis Annual 12 (2005): 12-28.

Morrow, Bradford and Bernard Lafourcade. A Bibliography of the Writings of Wyndham Lewis. Santa Barbara: Black Sparrow Press, 1978.

Mosley, Sir Oswald. My Life. London: Thomas Nelson and Sons Ltd., 1968.

Muggeridge, Malcolm. "Left Wings Over Europe." Review of Left Wings Over Europe, by Wyndham Lewis. Now and Then 54 (Summer): 5-6.

-----. The Thirties: 1930-1940 in Great Britain. London: Collins, 1967.

Munton, Alan. "A Reading of The Childermass." In Meyers, ed., Wyndham Lewis: A Revaluation, 120-132.

-----. "Fantasies of Violence: The Consequences of Not Reading Wyndham Lewis." Wyndham Lewis Annual 5 (1998): 31-49.

----. "George Orwell, Wyndham Lewis and the Origins of Cultural Studies." Paper presented at the 9th International 'Culture and Power' conference, Orwell Centenary section, Faculty of Letters of the University of Lisbon, November 4-7, 2003. Dave Harris \& Colleagues: Essays, Papers, and Courses. Eds. A. Harris and M Rapsomanikis. http://www.arasite.org/ampage.html.

-----. "'Imputing Noxiousness': Aggression and Mutilation in Recent Lewis Criticism." Wyndham Lewis Annual 4 (1997): 5-20.

-----. "The Politics of Wyndham Lewis." PN Review 4.1 (1976): 34-39. 
-----. Review of Fredric Jameson's Fables of Aggression: Wyndham Lewis, the Modernist as Fascist. In Cooney, Blast 3, 345-351.

-----. “Wyndham Lewis: From Proudhon to Hitler (and back): the Strange Political Journey of Wyndham Lewis." EREA 4, no.2 (Autumn 2006): 27-33.

-----. "Wyndham Lewis Our Contemporary." Introduction to Wyndham Lewis the Radical, edited by Carmelo Cunchillos Jaime, 7-19.

-----. "Wyndham Lewis: the relation between the theory and the fiction, from his earliest writings to 1941." PhD diss., Cambridge University, 1976.

Murray, Brian James. "Awaiting the Apocalypse: The Later Novels and Short Stories of Percy Wyndham Lewis." PhD diss., University of Tulsa, 1980.

Nashe, Thomas. The Unfortunate Traveller. In The Unfortunate Traveller and Other Works, by Thomas Nashe, edited by J.B. Steane, 251-370. London: Penguin, 1985. Reprinted from 1972 edition.

Nath, Michael. "“Monstrous Starlight': Wyndham Lewis and Gnosticism." In Edwards, ed., Volcanic Heaven, 149-167.

Neilson, Brett Maxwell. “Wyndham Lewis as Crowd.” PhD diss., Yale University, 1994. Nichols, Ray. Treason, Tradition, and the Intellectual: Julien Benda and Political Discourse. Lawrence: Regents Press of Kansas, 1978.

Nietzsche, Friedrich. The Will to Power. Translated by Walter Kaufmann and R.J. Hollingdale. Edited by Walter Kaufmann. New York: Random House, 1967. First published 1901.

Normand, Tom. Wyndham Lewis the Artist: Holding the Mirror Up to Politics. 
Cambridge: Cambridge University Press, 1992.

O'Keeffe, Paul. Some Sort of Genius: A Life of Wyndham Lewis. London: Pimlico, 2001.

Ophir, Ella Zohar. "Toward a Pitiless Fiction: Abstraction, Comedy, and Modernist Antihumanism." Modern Fiction Studies 52, no.1 (Spring 2006): 92-121.

Panichas, George A. Introduction to Regnery, A Few Reasonable Words: Selected Writings, xi-xxv.

Parsons, D.S.J. "Roy Campbell and Wyndham Lewis." Papers on Language and Literature 7, no.4 (Fall 1971): 406-21.

Pearce, Joseph. Bloomsbury and Beyond: The Friends and Enemies of Roy Campbell. London: HarperCollins Publishers, 2001.

Penny, Jonathon. "An Experiment in Critical Modernism: Eschatology, Prophecy, and Revelation in Lewis, Huxley, and Golding." PhD diss., University of Ottawa, 2006.

Pero, Allan Clarke. "Wyndham Lewis and the Vortex of Modernity." PhD diss., University of Toronto, 2003.

Perrino, Mark. The Poetics of Mockery: Wyndham Lewis's The Apes of God and the Popularization of Modernism. Modern Humanities Research Association Texts and Dissertations. Volume 40. Leeds: W.S. Maney and Son, 1995.

Phillips, Ivan. "Enemy Lines: Form, Politics and Identity in Wyndham Lewis's One-Way Song." Wyndham Lewis Annual 12 (2005): 59-79.

Porteus, Hugh Gordon. Wyndham Lewis: A Discursive Exposition. London: Desmond Harmsworth, 1932. 
Pound, Omar and Philip Grover. Wyndham Lewis: A Descriptive Bibliography. Folkestone, Kent: Dawson 1978.

Powe, B.W. The Solitary Outlaw. Toronto: Lester and Orpen Dennys, 1987.

Prakash, Ravendra. The Literary Criticism of Wyndham Lewis. Jaipur: Pointer Publishers, 1989.

Pritchard, William. Wyndham Lewis. The Profiles in Literature Series. General editor B.C. Southam. London: Routledge and Kegan Paul, 1972.

Proudhon, Pierre-Joseph. Selected Writings of Pierre-Joseph Proudhon. Translated by Elizabeth Fraser. Edited by Stewart Edwards. Garden City, NY: Anchor Books, 1969.

Puchner, Martin. "The Aftershocks of Blast: Manifestos, Satire, and the Rear-Guard of Modernism." In Bad Modernisms, edited by Douglas Mao and Rebecca L.

Walkowitz, 44-67. Durham, NC: Duke University Press, 2006.

Quéma, Anne. The Agon of Modernism: Wyndham Lewis's Allegories, Aesthetics, and Politics. Lewisburg, PA: Bucknell University Press, 1999.

Ransom, John Crowe. "Flux and Blur in Contemporary Art." Sewanee Review 37, no.3 (July 1929): 353-366.

Regnery, Henry. A Few Reasonable Words: Selected Writings. Wilmington, Delaware: Intercollegiate Studies Institute, 1996.

--.-. Memoirs of a Dissident Publisher. New York: Harcourt Brace Jovanovich, 1979.

-----. Perfect Sowing: Reflections of a Bookman. Edited by Jeffrey O. Nelson. Wilmington, Delaware: ISI Books, 1999. 
-----. "Roy Campbell, Wyndham Lewis, T.S. Eliot, Ezra Pound." In Regnery, Memoirs of a Dissident Publisher, 194-220.

----.. "T.S. Eliot, Ezra Pound, and Wyndham Lewis: A Creative Friendship." In Regnery, A Few Reasonable Words, 287-320.

-----. "Wyndham Lewis: A Man Against His Time." In Regnery, Perfect Sowing, 82-111.

Riding, Laura. Anarchism is not Enough. Edited by Lisa Samuels. Berkeley: University of California Press, 2001. First published 1928.

Ridley, Jasper. Mussolini. New York: St. Martin’s Press, 1997.

Roberts, Michael. T.E. Hulme. New York: Haskell House, 1971. First published 1938.

Rose, W.K., ed. The Letters of Wyndham Lewis. London: Methuen and Co. Ltd., 1963.

Rosenthal, Raymond, ed. McLuhan: Pro and Con. Baltimore: Pelican Books, 1969. First published 1968.

Rousseau, Jean-Jacques. The Social Contract. Translated by Maurice Cranston. London: Penguin Books, 1968.

Russell, John. "Proletarian Tragedy: Wyndham Lewis' 'Revenge for Love'." Modern Age 27, no. 1 (Winter 1983): 61-66.

Salt, Jim. "The Electric Desert: A Study of the Myths of New Technology in the Works of Wyndham Lewis, with Particular Attention to The Apes of God and The Childermass." PhD diss., McGill University, 1972.

Sartre, Jean-Paul. Anti-Semite and Jew. Translated by George J. Becker. New York: Black Cat, 1962. First published 1946.

Schapiro, J. Salwyn. "Pierre Joseph Proudhon, Harbinger of Fascism." The American 
Historical Review 50, no. 4 (July 1945): 714-737.

Schenker, Daniel. "Homo ex Machina: Wyndham Lewis on the Definitions of Man." In Cooney, ed., Blast 3, 96-108.

-----. Wyndham Lewis: Religion and Modernism. Tuscaloosa: University of Alabama Press, 1992.

Schmitt, Carl. The Concept of the Political. Expanded edition. Translated by George Schwab. Chicago: The University of Chicago Press, 2007. First published 1932.

-----. The Crisis of Parliamentary Democracy. Translated by Ellen Kennedy. Cambridge, Massachusetts: The MIT Press, 1985. Second edition first published 1926.

Schopenhauer, Arthur. "On Aesthetics." In Essays and Aphorisms, selected and translated by R.J. Hollingdale, 155-165. London: Penguin, 1988. Reprint of 1970 edition. Selby, James. "The Physics of the Not-Self: Lewis and the Vedanta." Enemy News, no.31 (Winter 1990): 4-9.

Segrè, Claudio G. Italo Balbo: A Fascist Life. Berkeley: U of California P, 1987.

Sherry, Vincent. Ezra Pound, Wyndham Lewis, and Radical Modernism. New York: Oxford University Press, 1993.

Sisson, C.H. "The Politics of Wyndham Lewis." In Essays on Wyndham Lewis, 109-16.

Smith, Stan. "Re-Righting Lefty: Wyndham and Wystan in the Thirties." Wyndham Lewis Annual 9-10 (2002-2003): 34-45.

Smith, T. Alexander, and Raymond Tatalovich. Cultures at War: Moral Conflicts in Western Democracies. Peterborough: Broadview Press, 2003.

Snow, C.P. The Two Cultures and A Second Look. Cambridge: Cambridge University 
Press, 1982. Reprint of 1969 paperback edition. Part I first published 1959. Part II first published 1964.

Sorel, George. "The Decomposition of Marxism." Translated by Irving Louis Horowitz. In Horowitz, Radicalism and the Revolt Against Reason, 207-254.

-----. Reflections on Violence. Translated by T.E. Hulme and J. Roth. New York: Collier Books, 1974. Reprint of 1961 edition. First published 1908.

-----. "Unity and Multiplicity." Appendix 1 of Reflections on Violence, second edition, by George Sorel. In Sorel, Reflections on Violence, 250-273.

Spengler, Oswald. The Decline of the West. Vol. 1. 1918. Trans. Charles Francis Atkinson. New York: Knopf, 1928.

Stirner, Max. The Ego and Its Own. Edited by David Leopold. Cambridge Texts in the History of Political Thought. Cambridge: Cambridge University Press, 1995. First published 1844.

Stockton, Sharon Marie. "Aesthetics, Politics, and the Staging of the World: Wyndham Lewis and the Renaissance." Twentieth Century Literature 42, no.4 (Winter 1996): 494-515.

Stone, Albert E., Jr. "Seward Collins and the American Review: Experiment in ProFascism, 1933-37." American Quarterly 12, no.1 (Spring 1960): 3-19.

Stone, Geoffrey. "The Ideas of Wyndham Lewis." American Review 1, no.5 (October 1933): 578-99.

-----. "The Ideas of Wyndham Lewis: Part II." American Review 2, no.1 (November 1933): 1-96. 
---.-. “A New Book by Wyndham Lewis.” Review of Left Wings Over Europe, by Wyndham Lewis. American Review 7, no. 5 (1936): 564-85.

Strauss, Leo. On Tyranny: Including the Strauss-Kojève Correspondence. Edited by Victor Gourevitch and Michael S. Roth. Chicago: The University of Chicago Press, 2000.

-----. Persecution and the Art of Writing. Chicago: The University of Chicago Press, 1988. First published 1952.

Surette, Leon. Pound in Purgatory: From Economic Radicalism to Anti-Semitism. Urbana: University of Illinois Press, 1999.

Swift, Jonathan. A Tale of a Tub and Other Works. Edited by Angus Ross and David Woolley. Oxford: Oxford University Press, 1986. First published 1704.

Symons, Julian. The Thirties and the Nineties. Manchester: Carcanet Press Limited, 1990. First published 1960 as The Thirties: A Dream Revolved by Cresset Press. Revised in 1975. 1990 edition contains postscript.

Thomas, Hugh. The Spanish Civil War. Revised edition. Harmondsworth, Middlesex: Penguin, 1965. First published 1961.

Tomlin, E.W.F. "The Philosopher-Politician." Twentieth Century Verse no.6-7 (November/December 1937): 135-139.

-----. Wyndham Lewis. Writers and their Work. Number 64. London: Longmans, Green and Co., 1955.

-.---. "Wyndham Lewis the Emancipator." In Cooney, Blast 3, 109-113.

Twelve Southerners. I'll Take My Stand: The South and the Agrarian Tradition. New 
York: Peter Smith, 1951. First published 1930 by Harper and Brothers.

Wagner, Geoffrey. "The Fascist Mentality: Wyndham Lewis." Weiner Library Bulletin n.s. 12, 22, no.3 (Summer 1968): 35-40.

-..-.-. Wyndham Lewis: A Portrait of the Artist as the Enemy. London: Routledge and Kegan Paul, 1957.

Waller, Bruce. Bismarck. Historical Association Studies. Oxford: Basil Blackwell Ltd., 1985.

Watson, Sheila. "Myth and Counter-Myth." Sheila Watson: A Collection. Open Letter 3rd series, no.1. (1975): 119-136.

-----. “Unaccommodated Man.” Sheila Watson: A Collection. Open Letter 3rd ser., no.1. (1975): 97-114.

-----.. Wyndham Lewis and Expressionism. Waterloo: MLR Editions Canada, 2003. Reprinted from a previously unpublished 1964 doctoral thesis.

-----. "Wyndham Lewis and G.K. Chesterton." The Chesterton Review 6, no.2 (Spring-Summer 1980): 254-271.

Williams, Louise Blakeney. Modernism and the Ideology of History: Literature, Politics, and the Past. Cambridge: Cambridge University Press, 2002.

Weber, Eugen. Varieties of Fascism: Doctrines of Revolution in the Twentieth Century. New York: Anvil Books, 1964.

Woodcock, George. "A Personal Preface to the Third Edition." Preface to Pierre-Joseph Proudhon: A Biography, by George Woodcock, $3^{\text {rd }}$ edition, xiii-xx. Montreal: Black Rose Books, 1987. First published 1956. 
------, ed. Wyndham Lewis in Canada. Canadian Literature Series. General editor George Woodcock. Vancouver: University of British Columbia, 1971.

Worringer, Wilhelm. Abstraction and Empathy: A Contribution to the Psychology of

Style. Translated by Michael Bullock. New York: International University Press, 1967. First published 1908.

Wragg, David A. Wyndham Lewis and the Philosophy of Art in Early Modernist Britain: Creating a Political Aesthetic. Studies in Art History 11. Lewiston: Edwin Mellen Press, 2005.

Young, Alan. Dada and After: Extremist Modernism and English Literature. Manchester: Manchester University Press, 1981. 